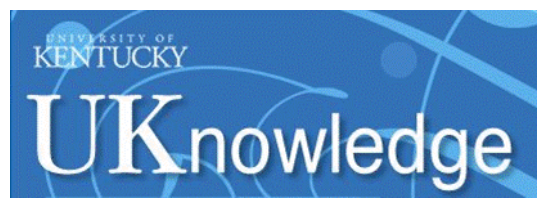

University of Kentucky

UKnowledge

Theses and Dissertations--Earth and

Environmental Sciences

Earth and Environmental Sciences

2020

\title{
IDENTIFICATION OF THE CAUSES AND EXTENT OF ELEVATED \\ METHANE CONCENTRATIONS IN THE GROUNDWATER OF EASTERN KENTUCKY
}

Cristopher Alvarez Villa

University of Kentucky, csalvarezv@gmail.com

Digital Object Identifier: https://doi.org/10.13023/etd.2020.486

Right click to open a feedback form in a new tab to let us know how this document benefits you.

\section{Recommended Citation}

Alvarez Villa, Cristopher, "IDENTIFICATION OF THE CAUSES AND EXTENT OF ELEVATED METHANE CONCENTRATIONS IN THE GROUNDWATER OF EASTERN KENTUCKY" (2020). Theses and Dissertations-Earth and Environmental Sciences. 83.

https://uknowledge.uky.edu/ees_etds/83

This Master's Thesis is brought to you for free and open access by the Earth and Environmental Sciences at UKnowledge. It has been accepted for inclusion in Theses and Dissertations--Earth and Environmental Sciences by an authorized administrator of UKnowledge. For more information, please contact UKnowledge@lsv.uky.edu. 


\section{STUDENT AGREEMENT:}

I represent that my thesis or dissertation and abstract are my original work. Proper attribution has been given to all outside sources. I understand that I am solely responsible for obtaining any needed copyright permissions. I have obtained needed written permission statement(s) from the owner(s) of each third-party copyrighted matter to be included in my work, allowing electronic distribution (if such use is not permitted by the fair use doctrine) which will be submitted to UKnowledge as Additional File.

I hereby grant to The University of Kentucky and its agents the irrevocable, non-exclusive, and royalty-free license to archive and make accessible my work in whole or in part in all forms of media, now or hereafter known. I agree that the document mentioned above may be made available immediately for worldwide access unless an embargo applies.

I retain all other ownership rights to the copyright of my work. I also retain the right to use in future works (such as articles or books) all or part of my work. I understand that I am free to register the copyright to my work.

\section{REVIEW, APPROVAL AND ACCEPTANCE}

The document mentioned above has been reviewed and accepted by the student's advisor, on behalf of the advisory committee, and by the Director of Graduate Studies (DGS), on behalf of the program; we verify that this is the final, approved version of the student's thesis including all changes required by the advisory committee. The undersigned agree to abide by the statements above.

Cristopher Alvarez Villa, Student

Dr. Andrea Erhardt, Major Professor

Dr. Michael McGlue, Director of Graduate Studies 


\title{
IDENTIFICATION OF THE CAUSES AND EXTENT OF ELEVATED METHANE CONCENTRATIONS IN THE GROUNDWATER OF EASTERN KENTUCKY
}

\author{
THESIS \\ A thesis submitted in partial fulfillment of the \\ requirements for the degree of Master of Science in the \\ College of Arts and Sciences \\ at the University of Kentucky

$$
\text { By }
$$$$
\text { Cristopher Steven Alvarez Villa }
$$$$
\text { Lexington, Kentucky }
$$ \\ Co-Directors: Dr. Andrea Erhardt, Assistant Professor of Earth and Environmental \\ Sciences \\ and Dr. Alan Fryar, Professor of Earth and Environmental Sciences \\ Lexington, Kentucky \\ 2020
}

Copyright $($ C Cristopher Steven Alvarez Villa 2020 


\section{ABSTRACT OF THESIS}

\section{IDENTIFICATION OF THE CAUSES AND EXTENT OF ELEVATED METHANE CONCENTRATIONS IN THE GROUNDWATER OF EASTERN KENTUCKY}

Recent development of unconventional oil and gas (UOG) resources has prompted concerns about its potential impact on public health and the quality of water and air resources. Elevated dissolved methane concentrations $(>1 \mathrm{mg} / \mathrm{L})$ have been associated with proximity to UOG development and stray gas, but also with natural microbial activity. Baseline gas data, local hydrogeology and geochemistry context can aid assessment of methane sources and interactions. Methane concentrations in eastern Kentucky groundwater are above the "immediate action" level in some private/domestic water wells, show wide variations over small distances, and have been hypothesized to have different relationships to mining. This study suggests that groundwater in areas with extensive coal mining often has low methane concentrations due to sulfate production by pyrite oxidation. Microbial production of methane is common in groundwater, but sulfate-rich groundwater can limit methane production and sulfate-reducing conditions can be coupled with methane oxidation. Areas with a high density of oil and gas wells appear to be more likely to introduce thermogenic methane in groundwater. These results suggest that anthropogenic activities directly and indirectly influence geochemical conditions and methane distribution in groundwater in eastern Kentucky. Similar effects would be expected

throughout the Appalachian Basin and in areas with different levels of mining and oil and gas development.

KEYWORDS: isotopes, sulfate, redox, coal mining, oil and gas

$\frac{\text { Cristopher Steven Alvarez Villa }}{\text { (Name of Student) }}$

$11 / 24 / 2020$

Date 


\section{IDENTIFICATION OF THE CAUSES AND EXTENT OF ELEVATED METHANE}

CONCENTRATIONS IN THE GROUNDWATER OF EASTERN KENTUCKY

\section{By}

Cristopher Steven Alvarez Villa

Dr. Andrea Erhardt

Co-Director of Thesis

Dr. Alan Fryar

Co-Director of Thesis

Dr. Michael McGlue

Director of Graduate Studies

$11 / 24 / 2020$

Date 


\section{ACKNOWLEDGMENTS}

The following work would not have been possible without the support of many people. I would like to thank Dr. Andrea Erhardt and Dr. Alan Fryar for the opportunity to join their research labs and develop an exciting project. Their academic and moral support have been essential in my development as a geoscientist and a person. I am especially grateful to Dr. Erhardt for encouraging my research and professional pursuits, while keeping me on track to graduate. Many thanks to Dr. Marty Parris and Dr. Junfeng Zhu for being a part of my committee, and for their constant support and feedback on research ideas. Their prior research was fundamental to this thesis.

I would like to thank Steve Webb, Adam Nolte, Bart Davidson, UK Cooperative Extension officers and the Kentucky Geological Survey for the support sampling water wells and analyzing samples. Special thanks to Dr. Jordon Munizzi for his help getting the lab ready to analyze my samples and showing me how to do it. I would also like to thank Dr. Vanessa Fichtner for her support in the lab and for her time discussing research concepts. Thanks to Dr. Chris Matocha and Martin VanDiviere for their help analyzing samples as well.

Finally, I would like to thank my family for their unconditional love, support, and encouragement. I would not have gotten where I am without their hard work and all the opportunities they have given me. Thank you, Kelsey, for keeping me sane through so many months of quarantine and for being the absolute best. Thanks to all my labmates and friends for all their encouragement and feedback before many presentations. I could not have hoped for a more welcoming and supportive group of peers. 
This Work is supported by the Lyman T. Johnson Fellowship, USGS 104B Grant (awarded by KWRRI), Grants-in-Aid (AAPG), and the GSA Southeastern Section Grant. Thanks to the Department of Earth and Environmental Sciences for travel and research support through the Ferm and Brown-McFarland funds. Thanks to Isotech for their assistance analyzing samples. 


\section{TABLE OF CONTENTS}

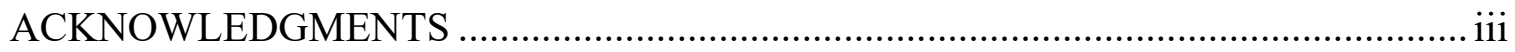

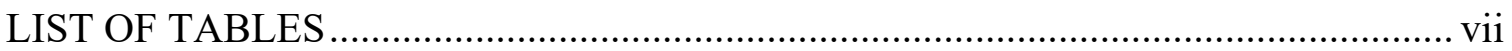

LIST OF FIGURES ….................................................................................. vii

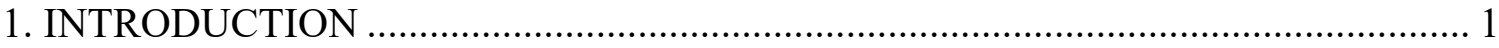

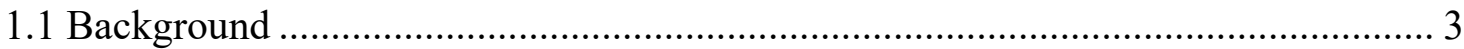

1.2 Relevant Anthropogenic/Industrial Influences................................................ 4

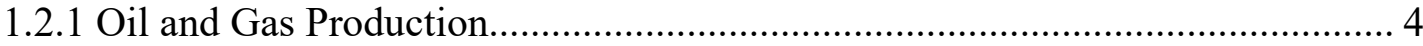

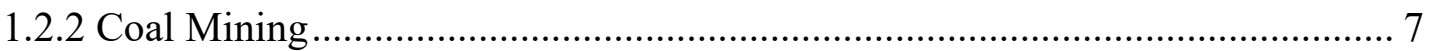

1.3 Geochemistry, Hydrogeology and Methane Dynamics ................................... 8

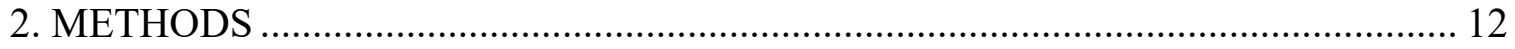

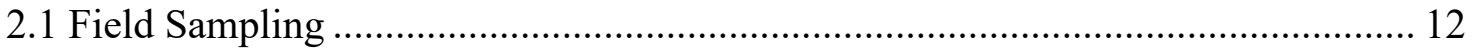

2.2 Chemical Analysis...................................................................................... 14

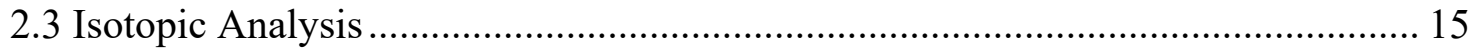

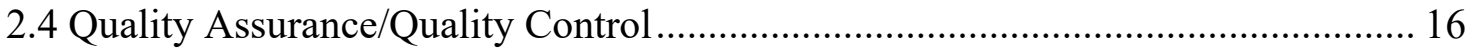

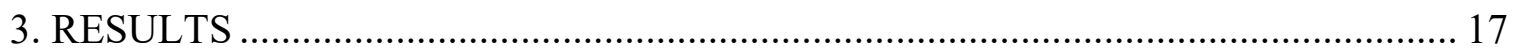

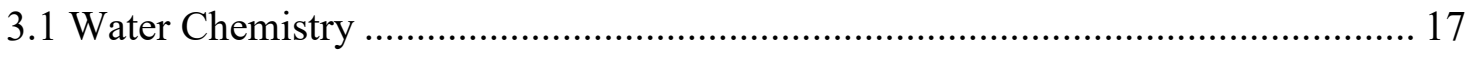

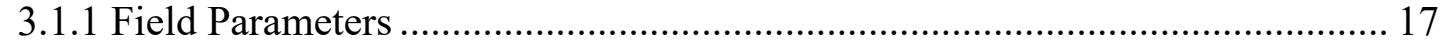

3.1.2 Total Metals and Anions............................................................................ 20

3.1.3 Dissolved Methane and Ethane Concentrations ........................................... 26

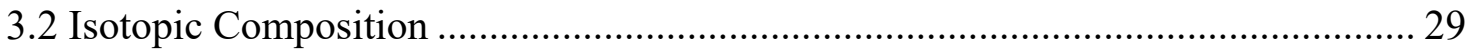

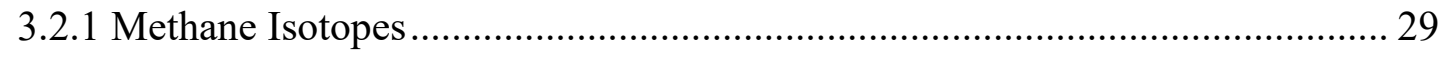

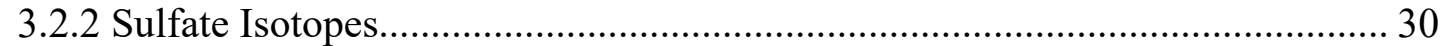

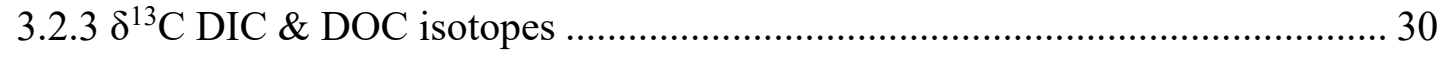

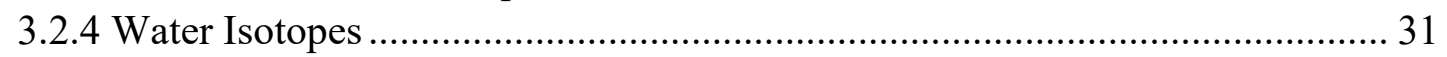

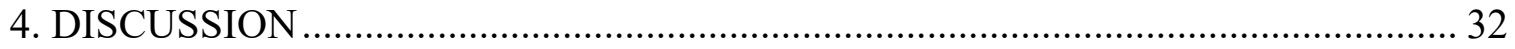

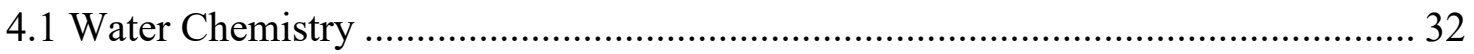

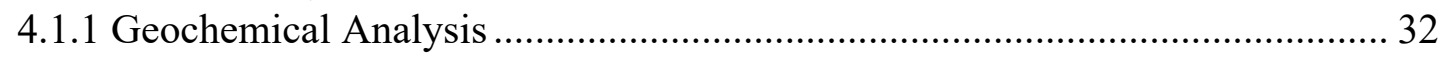

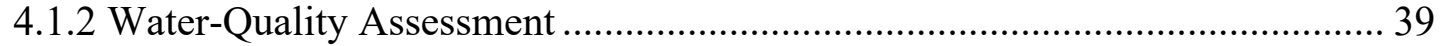


4.1.3 Geochemical Conditions Associated with Dissolved Methane.

4.2 Isotopic Composition and Geochemical Processes ............................................ 41

4.2.1 Methane Sources, Methanogenesis and Oxidation of Methane ....................... 41

4.2.2 Sulfate Sources and Bacterial Sulfate Reduction ........................................ 46

4.3 Redox Geochemical Interactions Between Methane and Sulfate .......................... 48

4.4 Spatial and Environmental Conditions Associated with Dissolved Methane ........ 50

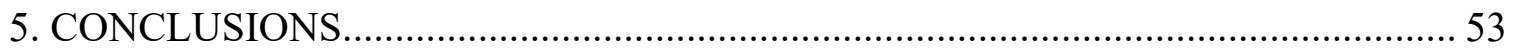

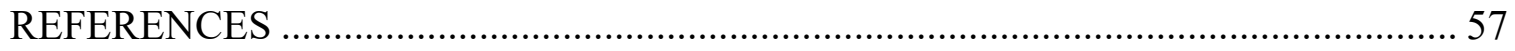

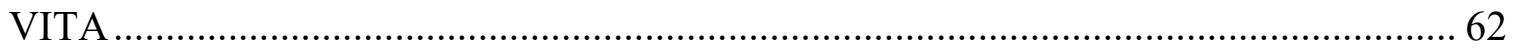




\section{LIST OF TABLES}

Table 1. Field parameters and sampling information of water wells............................. 17

Table 2. Concentrations of major cations and anions in water wells............................. 22

Table 3. Concentrations of minor metals and metalloids in water wells.......................... 23

Table 4. Concentrations of minor anions in water wells........................................... 25

Table 5. Dissolved gas concentrations and stable isotope composition of water wells.... 27

Table 6 . Correlations between water chemistry parameters and methane

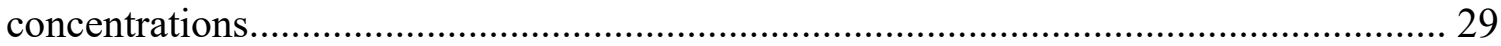

Table 7. Mineral saturation indexes (SI) in water samples.......................................... 34 


\section{LIST OF FIGURES}

Figure 1. Map of eastern Kentucky with the locations of the 24 water wells in this study and wells in Zhu et al. (2018) and LeDoux et al. (2016). The outline of the Rogersville play, mined-out areas, surficial geology, and faults are shown.

Figure 2. Schematic diagram of the relevant sources and sinks of methane defined in Whiticar (1999). Solid lines represent relevant processes, and dashed line represents a secondary process.

Figure 3. Modified Piper diagram of sampled water wells. Circle size is proportional to methane concentration.

Figure 4. Concentration of methane compared to water type in box-and-whisker diagram.

Figure 5. DIC concentrations in nine water samples compared to alkalinity measured in the field and in the lab. 31

Figure 6. DIC concentrations compared to $\delta^{13} \mathrm{C}$-DIC values. ......................................... 31 Figure 7. Bivariate plot of $\delta^{2} \mathrm{H}$ vs. $\delta^{18} \mathrm{O}$ data for this study and LeDoux et al. (2016). Blue and red lines are linear regressions of each study. Black line illustrates GMWL, gray line illustrates KMWL.

Figure 8. Comparison of methane concentrations between nine pairs of samples collected in glass bottles through the direct-fill method and analyzed at KGS and collected in Isoflask $^{\mathrm{TM}}$ containers and analyzed at Isotech. Black line represents 1:1 relationship, whereas dark blue line shows data trendline................................................................... 40 Figure 9. Genetic diagram of $\delta^{13} \mathrm{C}-\mathrm{CH}_{4}$ vs $\delta^{2} \mathrm{H}-\mathrm{CH}_{4}$ for eleven samples from seven wells, including data for three wells sampled in two sampling events shown with blue arrows. The blue dashed lines represent microbial-thermogenic transition/mixing. The red dashed line represents the change in composition with increasing thermal maturity. 42 Figure 10. Genetic diagram of $\delta^{13} \mathrm{C}-\mathrm{CH}_{4}$ vs $\mathrm{C}_{1} /\left(\mathrm{C}_{2}+\mathrm{C}_{3}\right)$ for fourteen samples from eleven wells, including data for three wells sampled in two sampling events. Blue dashed line represents microbial-thermogenic transition/mixing. 42 Figure 11. Genetic diagram of $\delta^{13} \mathrm{C}-\mathrm{CH}_{4}$ vs. $\delta^{13} \mathrm{C}_{-} \mathrm{CO}_{2}$ values for fifteen samples from twelve wells, including data for three wells sampled in two sampling events. 43 Figure 12. $\mathrm{CH}_{4}$ concentrations vs. $\delta^{13} \mathrm{C}$-DIC values. A trend of increasing methane concentration with increasing $\delta^{13} \mathrm{C}$-DIC, possibly due to methanogenesis, can be pointed out in a subset of samples (blue arrow). Three wells appear to follow a steeper trend (red arrow), and two wells a shallower one (gray arrow), possibly due to an extra input of methane and methane oxidation, respectively.

Figure $13 . \delta^{34} \mathrm{~S}_{-} \mathrm{SO}_{4}$ vs. $\delta^{18} \mathrm{O}-\mathrm{SO}_{4}$ values. Boxes represent common $\delta^{34} \mathrm{~S}$ and $\delta^{18} \mathrm{O}$ values for sulfate sources (Krouse and Mayer, 2000). Red dashed line is a representation of the trend observed for bacterial sulfate reduction.

Figure $14 . \delta^{34} \mathrm{~S}_{-} \mathrm{SO}_{4}$ vs. the inverse concentration of sulfate. Samples with a single source of sulfate have the same signature regardless of concentration (black box), whereas samples that have gone through bacterial sulfate reduction follow a trend of more positive $\delta^{34} \mathrm{~S}^{-\mathrm{SO}_{4}}$ values with decreasing sulfate concentrations (dark red arrows) 47 
Figure 15. Evolution of $\delta^{13} \mathrm{C}$-DIC values compared to sulfate concentrations. Blue dashed line represents methanogenesis trend. Red dashed line represents the trend of sulfate reduction. Samples in between these trendlines potentially have mixed processes.

Figure 16. Box-and-whisker plot of the distribution of water chemistry in areas with mining influence and oil and gas wells. The box contains the second and third quartiles and the bold middle line represents the median. Lower and upper error lines represent maximum and minimum values excluding potential outliers. Data points are scattered within each category

Figure 17. Water chemistry maps of the sampled wells.

Figure 18. Schematic cross-section of the geochemical processes most relevant to methane in eastern Kentucky in relation to fossil fuel development influences. Methane pathways are indicated by arrows and color indicates source, where blue is microbial, red is thermogenic, and gray is other. Blue dashed line represents groundwater table. Well A shows CR methanogenesis, and it also considers a secondary source from coal. Well B shows a mixture of $\mathrm{CR}$ methanogenesis and thermogenic sources. Well $\mathrm{C}$ shows no methane in the well, while BSR and methane oxidation can occur nearby.... 


\section{INTRODUCTION}

Horizontal drilling and high-volume hydraulic fracturing (HVHF, i.e. fracking) technology has transformed the energy industry by enabling the development of unconventional oil and gas (UOG) resources. Yet, the rapid implementation of this technique that induces fractures has generated concerns about its potential impact on water quality (Vengosh et al., 2014; Vidic et al., 2013), air quality (Colborn et al., 2014), and public health (Adgate et al., 2014). Numerous studies have been conducted to assess methane $\left(\mathrm{CH}_{4}\right)$, the main component of natural gas, and groundwater quality in relation to UOG activity in the continental USA (Claire Botner et al., 2018; Darrah et al., 2014; Humez et al., 2016; Jackson et al., 2013; LeDoux et al., 2016; Li et al., 2016; McIntosh et al., 2019; Osborn et al., 2011; Siegel et al., 2015; Wolfe and Wilkin, 2017; Zhu et al., 2018). These studies have considered datasets with 10 s to 10,000 s of water wells and have been focused in areas with tight and shale gas reservoirs such as the Marcellus and Utica shales in the Appalachian Basin, and underlying coalbed methane such as the Raton Basin in Colorado.

Concentrations and isotopic composition of dissolved hydrocarbon gases and noble gases in groundwater have been used in combination with modeling, geospatial, and statistical analysis to assess natural methane levels and anthropogenic influences. However, methane can be influenced by several factors and assessment of fossil fuel development influences requires an understanding of local and regional controls. For example, some studies have shown a positive correlation between methane concentrations in drinking water wells and proximity to areas with active drilling and hydraulic fracturing (Jackson et al., 2013; Osborn et al., 2011). Other studies, however, have shown no such 
correlation (LeDoux et al., 2016; Siegel et al., 2015; Zhu et al., 2018). Characterizing and understanding groundwater conditions before drilling provides a baseline reference for monitoring subsequent changes during and after fossil fuel development.

Methane dissolved in groundwater is an important health and safety concern as elevated concentrations of methane in groundwater can lead to accumulation of methane in enclosed areas and result in explosive environments (Eltschlager et al., 2001). Additionally, water quality in areas with stray gas contamination could be impacted in the long-term by brine and hydraulic fracturing fluids (Vengosh et al., 2014). Dissolved methane in groundwater and water quality is an issue particularly relevant in eastern Kentucky, where the Devonian Berea Sandstone oil play has been developed in recent years with small-scale hydraulic fracturing at relatively shallow depths $(<600 \mathrm{~m})(\mathrm{Zhu}$ et al., 2018). An additional potential UOG development in eastern Kentucky is the Cambrian Rogersville Shale. Large-scale hydraulic fracturing at depths of 2,000 to $4,000 \mathrm{~m}$ is expected to be similar to other large scale UOG plays in North America (Zhu et al., 2018) and could pose a risk to groundwater and water quality.

This study aimed to: 1) identify the spatial distribution of groundwater with elevated methane concentrations; 2) analyze the geochemical conditions possibly influencing that distribution; and 3) assess any influence from coal mining and oil and gas development in methane occurrence. To meet these objectives, bulk chemistry and isotopic composition of water from 24 private wells in eastern Kentucky have been analyzed. Methane composition is particularly investigated in relation to methanogenesis, methane oxidation, and bacterial sulfate reduction (BSR). Floyd, Knott, and Magoffin Counties were targeted for sampling to fill a geographic data gap of dissolved methane 
concentrations in groundwater, where no background/baseline data have been reported for dissolved gases. Geochemical and anthropogenic influences on methane occurrence has been assessed in a $\sim 1600 \mathrm{~km}^{2}$ region bounded by Zhu et al. (2018) and LeDoux et al. (2016) to the north and south of this study, respectively. This study establishes a better understanding of the geochemical conditions and anthropogenic factors (e.g. mining, and oil and gas development) associated with methane occurrence in groundwater in this region of the Appalachian Basin of eastern Kentucky.

\subsection{Background}

In 2014, LeDoux et al. (2016) sampled domestic water wells in Letcher County in southeastern Kentucky to determine dissolved methane sources and evaluate any influence from hydraulic fracturing in the Devonian Chattanooga Shale. A total of 59 domestic wells were sampled, 20 wells during winter (January to March) and 39 wells during summer (June to August). No water wells were observed with methane above $10 \mathrm{mg} / \mathrm{L}$. Carbon and hydrogen isotopes for methane in these wells suggested a low-maturity thermogenic and mixed thermogenic/biogenic origin.

From March through April 2016, the Kentucky Geological Survey (KGS) conducted sampling events as part of a study to assess baseline groundwater chemistry in relation to UOG development, water quality and methane sources in groundwater. To identify groundwater methane contamination, Zhu et al. (2018) analyzed 51 domestic wells in six counties in northeastern Kentucky within the Berea Sandstone oil play region. They identified 14 wells with dissolved methane above $10 \mathrm{mg} / \mathrm{L}$ (the action level of "warning, investigation" according to the US Department of the Interior Office of Surface Mining), including six wells with methane above $28 \mathrm{mg} / \mathrm{L}$ (“immediate action" level) (Eltschlager 
et al., 2001). Based on isotopic analysis, this methane was dominantly produced by microbial carbonate reduction (Zhu et al., 2018).

While groundwater methane data in eastern Kentucky are sparse, studies by LeDoux et al. (2016) and Zhu et al. (2018) showed elevated methane levels (>1 mg/L) in seven counties. Methane concentrations suggest no correlation with distance to oil and gas wells in either study. However, these studies found differing relationships between high methane concentrations and coal-mining activities. Whereas LeDoux et al. (2016) observed low methane concentrations near mining in southeastern Kentucky, Zhu et al. (2018) observed high methane concentrations near mining in northeastern Kentucky. LeDoux et al. (2016) argued that surface coal mining could increase secondary permeability by fracturing bedrock and enhance the oxygenation of groundwater via meteoric water recharge, consequently oxidizing methane and lowering its concentration. Zhu et al. (2018) interpreted elevated quantities of methane in groundwater to be derived from microbial sources via the carbon dioxide reduction pathway. Understanding the causes of different geochemical drivers, some of which may be anthropogenic, may provide guidelines to prevent future groundwater methane contamination.

\subsection{Relevant Anthropogenic/Industrial Influences}

\subsubsection{Oil and Gas Production}

Technological development in oil and gas drilling techniques in the last few decades has enabled the profitable extraction of hydrocarbons from shale and other organic-rich reservoirs with low permeability (Vengosh et al., 2014; Vidic et al., 2013). This can be accomplished through hydraulic fracturing, a process where fluids are injected under high pressure to develop networks of fractures connecting small pores filled with oil 
and gas. The composition of the injection fluids varies, but can include water, sand, biocides and other chemical additives that increase fracturing, prevent well casing problems, and enhance extraction (Vidic et al., 2013). Horizontal drilling technology is frequently used along with HVHF and allows producers to access resources not directly below the drilling sites.

Shallow groundwater can be contaminated with thermogenic methane through leaking gas wells and inadequate well casings (Hammond et al., 2020; McMahon et al., 2018; Sherwood et al., 2016). Aquifer vulnerability to hydrocarbon migration from development and leakage can be estimated through the characterization of multiphase (liquid and vapor) parameters of the formations between freshwater aquifers and production zones (Rice et al., 2018). However, groundwater flow in the geologic formations in eastern Kentucky is complex due to topography, stream incision, reservoir heterogeneity, and open fractures (Minns, 1993). Additionally, the long history of coal mining and hydrocarbon resource extraction and exploitation limits the identification of areas not disturbed by these (Wunsch, 1993).

Oil and gas development techniques in eastern Kentucky vary. The Berea Sandstone was developed with vertical wells as a gas play starting in the early 1900s (Parris and Nuttall, 2020). Hydraulic fracturing in the Chattanooga Shale in Letcher County has been recently completed at depths of 1000-1500 m using liquid nitrogen foam and vertical wells (LeDoux et al., 2016). In contrast, the Berea Sandstone has been mainly developed as an oil play in the last decade at shallow depths $(<600 \mathrm{~m})$ with horizontal drilling and small-scale hydraulic fracturing using slickwater, fracturing fluid that does not contain viscosity modifiers (Parris and Nuttall, 2020; Zhu et al., 2018). The area of development 
for the Berea oil play has been focused in four to five counties and is relatively small, compared to development of the Marcellus Shale, a major UOG play in Pennsylvania, and other UOG plays elsewhere in the United States. Unconventional development in the Marcellus play consumes tens of millions of liters of fresh water and more than a million kilograms of sand per well (Jiang et al., 2014; King, 2012), whereas in the Berea oil play extraction has involved hundreds of thousands of liters of fluid and tens to hundreds of thousands of kilograms of sand (Zhu et al., 2018).

While dissolved methane data in eastern Kentucky have been collected following conventional fossil fuel development, data collection in this study and in Zhu et al. (2018) occurred during early unconventional development of the Berea oil play, and would be representative of pre-drilling conditions in relation to the Rogersville play. Economic viability of Cambrian Rogersville Formation development is being evaluated (Harris et al., 2016). Extraction would employ HVHF at depths of 2000-4000 m with magnitude similar to stimulations in the Marcellus Shale.

Alvarez et al. (2018) argued that methane emissions to the atmosphere from the oil and gas industry, particularly from abnormal operating conditions in the production sector, are higher than reported by the U.S. Environmental Protection Agency. This discrepancy in emissions from abnormal conditions could potentially include gas migration to groundwater. Therefore, it is essential to identify unrecognized or underestimated sources and migration of methane. Extensive baseline geochemical sampling and water-quality analysis will improve understanding of methane sources and pathways. 


\subsubsection{Coal Mining}

The eastern and western parts of Kentucky contain the central Appalachian and Illinois Basins, respectively. Both basins contain economically important coal deposits from the Pennsylvanian period (320 to 280 million years old). Mineable coal is greater than 28 inches $(71 \mathrm{~cm})$, has a bituminous rank and contains less than $15 \%$ ash content after processing (Ellis et al., 2016). Mining operations can take place on the surface or underground and can employ different approaches depending on the local conditions such as geography and hydrogeology. Kentucky produced 36.1 million metric tons of coal in 2018, 43\% coming from eastern Kentucky. Surface mining operations in eastern Kentucky accounted for $54 \%$ of coal produced, where mining commonly employs drift, contour, and auger mining. As of 2014, the Eastern Kentucky Coal Field was estimated to have $~ 16.5$ billion metric tons remaining from the original coal resources $>14$ inches $(36 \mathrm{~cm})$ estimated at $\sim 40.3$ billion metric tons (Ellis et al., 2016). Only $\sim 6.7$ billion metric tons are mineable and $>28$ inches $(71 \mathrm{~cm})$.

The Eastern Kentucky Coal Field extends over an area of $\sim 27,000 \mathrm{~km}^{2}$. While mining is only actively occurring in some zones, it has disturbed most of the coal field area (Wunsch, 1993). Eastern Kentucky coals have very low maturity, low concentrations of coalbed methane, relatively high heat content ( 24.6 MMBtu per ton), and low sulfur content (0.98\%) (Ellis et al., 2016; Hower and Rimmer, 1991). However, the composition of methane in coal in eastern Kentucky has not been analyzed. Methane from coal seams can be associated with microbial and thermogenic methane depending on thermal maturity (Strąpoć et al., 2011). 


\subsection{Geochemistry, Hydrogeology and Methane Dynamics}

Studies at national and regional scales (McMahon et al., 2017; Molofsky et al., 2013), have identified elevated methane concentrations in groundwater to be largely controlled by local hydrogeological and geochemical interactions. In the Appalachian Basin, microbial methane has been recognized as a prevalent phenomenon (Molofsky et al., 2016a). High methane concentrations are often associated with sodium-rich waters, old groundwater ( $>60$ years), and low concentrations of oxygen, nitrate- $\mathrm{N}$, and sulfate $(<0.5$ $\mathrm{mg} / \mathrm{L}$ ) (McMahon et al., 2017). Similar associations of elevated methane concentrations with hydrogeological and geochemical controls are observed in groundwater in eastern Kentucky (LeDoux et al., 2016; Zhu et al., 2018).

Water wells in this study are in the western limb of the Appalachian Basin and underlying geology indicates a slight structural dip towards the southeast (Figure 1). Aquifers are predominantly located in Pennsylvanian clastic units from the Lee, Breathitt, and Conemaugh formations (Rice, 2001). Groundwater flow in eastern Kentucky is controlled by climate, topography, heterogeneity of geological units, coal beds, fracture zones, and underground and surface anthropogenic alterations, such as mining and oil and gas development (Minns, 1993). These aquifer attributes mainly support local flow systems within a shallow-fracture zone, and a regional system with downward flow beneath ridges

or upland areas. The lateral extent of Pennsylvanian aquifers is poorly defined but appears to be laterally discontinuous. Limited hydrological communication can result in large variations in chemical and isotopic composition over short distances (Zhu et al., 2018). Therefore, correlations over large distances can be challenging. In addition, spatial and 
temporal variations in the natural concentrations of methane can have huge effects in studies trying to identify impacts from anthropogenic activities (Rivard et al., 2018).

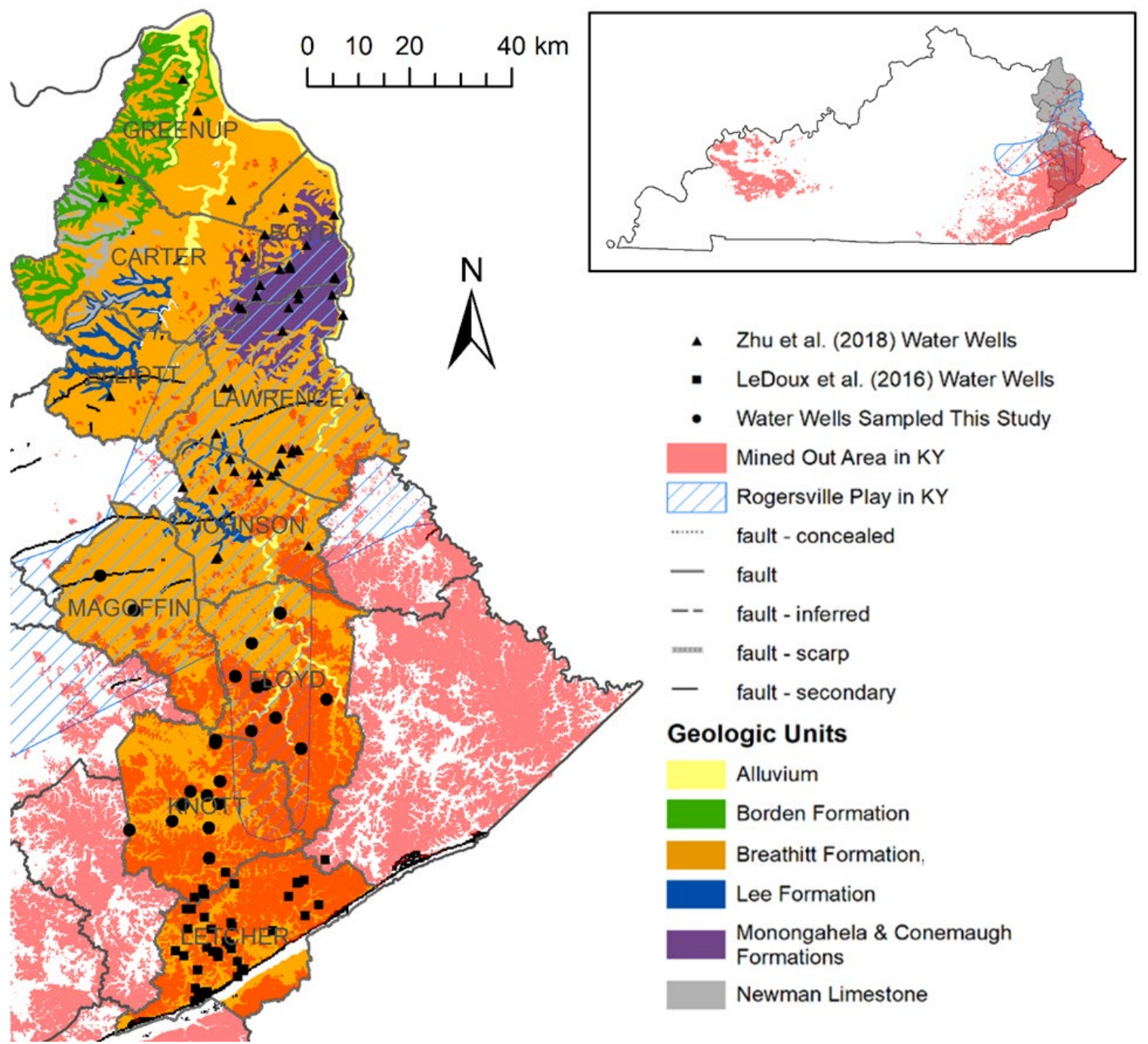

Figure 1. Map of eastern Kentucky with the locations of the 24 water wells in this study and wells in Zhu et al. (2018) and LeDoux et al. (2016). The outline of the Rogersville play, mined-out areas, surficial geology, and faults are shown.

Methane can be produced by methanogens by the reduction of $\mathrm{CO}_{2}$ or organic compounds such as acetate or methanol, and through the catagenesis of organic kerogens in source rocks:

$$
\begin{array}{ll}
\mathrm{CO}_{2} \text {-reduction: } & \mathrm{CO}_{2}+8 \mathrm{H}^{+}+8 \mathrm{e}^{-} \rightarrow \mathrm{CH}_{4}(\mathrm{aq})+2 \mathrm{H}_{2} \mathrm{O}, \text { or } \\
& \mathrm{HCO}_{3}^{-}+\mathrm{H}^{+}+4 \mathrm{H}_{2}(\mathrm{aq}) \rightarrow \mathrm{CH}_{4}(\mathrm{aq})+3 \mathrm{H}_{2} \mathrm{O}
\end{array}
$$


Acetate fermentation:

$$
\begin{aligned}
& \mathrm{CH} 3 \mathrm{COO}^{-}+\mathrm{H}^{+} \rightarrow \mathrm{CH}_{4}(\mathrm{aq})+\mathrm{CO}_{2} \text {, or } \\
& \mathrm{CH}_{3} \mathrm{COO}^{-}+\mathrm{H}_{2} \mathrm{O} \rightarrow \mathrm{CH}_{4}(\mathrm{aq})+\mathrm{HCO}_{3}{ }^{-}
\end{aligned}
$$

The microbial reduction of $\mathrm{CO}_{2}$ or organic matter is associated with a kinetic isotope effect (KIE) in which fractionation of $\mathrm{C}$ and $\mathrm{H}$ in $\mathrm{CH}_{4}$ delineates fields with different isotopic signatures for each pathway (Figure 2) (Milkov and Etiope, 2018; Whiticar, 1999). The reduction of $\mathrm{CO}_{2}$ to $\mathrm{CH}_{4}$ produces $\delta^{13} C-\mathrm{CH}_{4}$ values as negative as $-110 \%$ (vs. PDB) and $\delta^{2} \mathrm{H}-\mathrm{CH}_{4}$ values from $-250 \%$ to $-100 \%$ (vs. SMOW). The fermentation of methylated substrates leads to slightly more positive $\delta^{13} C-\mathrm{CH}_{4}$ values (from $-90 \%$ o to $-50 \%$ ) and $\delta^{2} H$ $\mathrm{CH}_{4}$ values as negative as $-531 \%$.

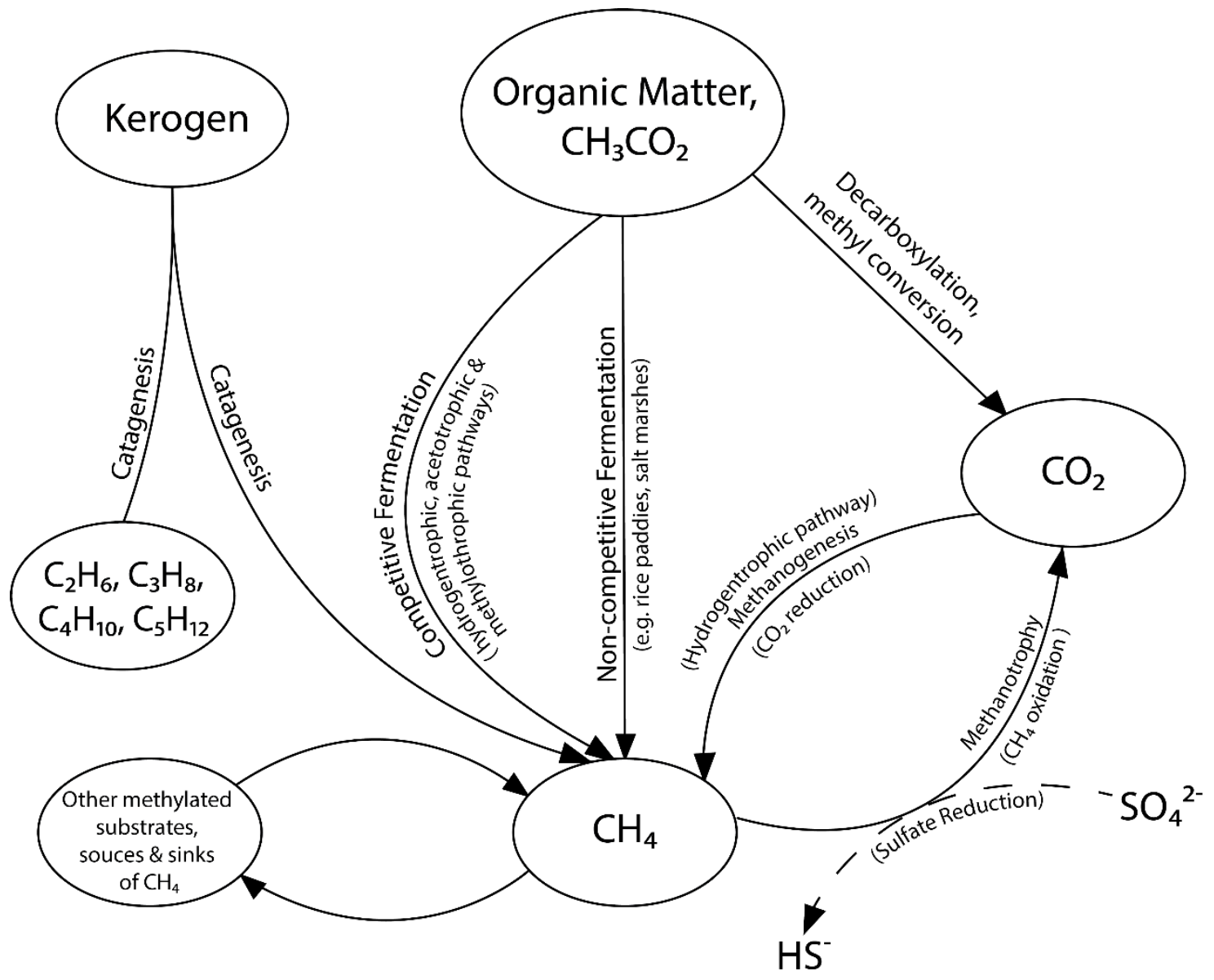

Figure 2. Schematic diagram of the relevant sources and sinks of methane defined in Whiticar (1999). Solid lines represent relevant processes, and dashed line represents a secondary process. 
In contrast, the production of thermogenic methane leads to $\delta^{13} \mathrm{C}_{-} \mathrm{CH}_{4}$ values extending from $-70 \%$ to $-15 \%$, and $\delta^{2} H-\mathrm{CH}_{4}$ values from $-350 \%$ to $-95 \%$. The identification of methane sources and pathways from its isotopic composition can hence be used to differentiate between microbial and thermogenic fluxes of methane (Osborn et al., 2011). The $\delta^{13} \mathrm{C}-\mathrm{CH}_{4}$ and $\delta^{2} \mathrm{H}-\mathrm{CH}_{4}$ values in thermogenic gases are significantly more positive than in microbial gases due to a more positive parent material (kerogen or oil) and higher generation temperatures, where fractionation is smaller. Similarly, methane consumption can be distinguished from methanogenesis by examining $\delta^{13} C-\mathrm{CH}_{4}$ and $\delta^{13} \mathrm{C}$ $\mathrm{CO}_{2}$ values.

In mixing and transition areas, $\delta^{13} \mathrm{C}-\mathrm{CH}_{4}$ values and gas ratio between methane and the sum of ethane $\left(\mathrm{C}_{2} \mathrm{H}_{6}\right)$ and propane $\left(\mathrm{C}_{3} \mathrm{H}_{8}\right), \mathrm{CH}_{4} /\left(\mathrm{C}_{2} \mathrm{H}_{6}+\mathrm{C}_{3} \mathrm{H}_{8}\right)$ or $\mathrm{C}_{1} /\left(\mathrm{C}_{2}+\mathrm{C}_{3}\right)$, can be used to further differentiate between sources. Also known as gas wetness, the gas ratio is typically $<100$ for thermogenic gases due to higher concentrations of ethane and propane, oil associated gases. The compositional ranges for thermogenic and microbial methane have been recently revised based on worldwide dataset with thousands of samples (Milkov and Etiope, 2018).

Microorganisms can mediate electron transfer in chemical reactions to consume some of the released energy. They can oxidize reduced species such as acetate $\left(\mathrm{CH}_{3} \mathrm{COO}^{-}\right.$ ) or dihydrogen $\left(\mathrm{H}_{2}\right)$ and reduce oxidized species like nitrate $\left(\mathrm{NO}_{3}{ }^{-}\right)$, ferric iron $\left(\mathrm{Fe}^{3+}\right)$ and sulfate, depending on the availability of solutes (Bethke et al., 2011). Sulfate-reducing bacteria (SRB), which reduce sulfate while oxidizing organic matter or $\mathrm{H}_{2}$, may compete with methanogens for substrates depending on their concentrations (Schlegel et al., 2011). Microbial activity, especially methanogenesis, can be negatively affected by trace metals 
such as copper at high concentrations, extreme $\mathrm{pH}$ conditions $(<4$ and $>9)$, and the pore size of growth locations and pathways (Schlegel et al., 2011). However, methanogens can also be resistant to high temperatures and extreme salinity, and are enhanced by phosphate (Schlegel et al., 2011).

\section{METHODS}

\subsection{Field Sampling}

A total of 24 private water wells were sampled in 2019; 13 wells are in Knott County, nine wells in Floyd County, and two wells in Magoffin County (Figure 1). Samples from 18 private water wells were collected in April and May 2019 in two sampling trips. In October 2019, samples were collected from six additional wells and three previously analyzed wells in a third trip. The Kentucky Groundwater Data Repository was used to find well records based on the map coordinates of wells. Only four AKGWA (Assembled Kentucky Ground Water Database) records matched the approximate field coordinates, and two of these records matched the well owner names. In the absence of a well record, information was gathered from nearby wells. Nineteen wells were identified without an AKGWA record.

Water-well owners were generally unaware of the depths of their wells and the estimated well depths were between 5 and $100 \mathrm{~m}$. Wells with unknown depths are thought to be relatively shallow $(<20 \mathrm{~m})$ due to the pumping systems observed. Five wells did not have pumping systems and were sampled using a Grundfos ${ }^{\circledR}$ two-inch submersible water pump; three of these were shallow hand-dug wells and two were drilled wells. Water levels were recorded before and after for wells without established pumping systems. 
Sample collection followed recommendations in Molofsky et al. (2018) to avoid sample degassing and significant changes in methane concentrations when possible. If accessible, water samples were preferentially collected at the outlet of pressure tanks, and prior to filtration and water treatment systems. When this was not possible, samples were taken from the faucet closest to the pressure tank. Water wells were purged at a pumping rate of 3 gallons per min $(11.4 \mathrm{~L} / \mathrm{min})$ to remove standing water in pressure tanks and water lines. Field parameters (oxidation-reduction potential (ORP), dissolved oxygen (DO), specific conductance (SC), $\mathrm{pH}$, and temperature) were monitored using a YSI multiparameter meter connected to a flow-through cell and recorded every 3-5 minutes once purging started. Sampling started after field parameters stabilized, which was assumed to happen after at least three well volumes. All field parameters were calibrated for the YSI meter every day before sampling. The same procedures were performed for all samples, with a few exceptions due to lab availability and sample suitability. Water samples were kept on ice immediately after collection, during transport, and stored at $4^{\circ} \mathrm{C}$ before laboratory analyses.

Additional analyses were conducted in the field and in the lab for some of the sampling trips. Samples from the third trip were analyzed for dissolved inorganic carbon (DIC) concentrations, organic anions, $\delta^{13} C$-DOC (dissolved organic carbon), and gases collected in IsoFlask ${ }^{\mathrm{TM}}$ containers and analyzed by Isotech. Samples from the second and third trip were analyzed for sulfate in the field. Isotopic data are not available for all samples because of low analyte concentrations. 


\subsection{Chemical Analysis}

Alkalinity was measured in the field with a $\mathrm{HACH}$ test kit using a digital titrator. Instrumental test kits (CHEMetrics) were used to estimate dissolved ferrous iron $\left(\mathrm{Fe}^{2+}\right)$, sulfide $\left(\mathrm{S}^{2-}\right)$, and sulfate $\left(\mathrm{SO}_{4}{ }^{2-}\right)$ concentrations in the field. The sulfide test kit follows a methylene blue measuring method with a $0-6 \mathrm{mg} / \mathrm{L}$ range; expected accuracy is $<0.3 \mathrm{mg} / \mathrm{L}$ at $0 \mathrm{mg} / \mathrm{L}$ and $\pm 30 \%$ at $0.6 \mathrm{mg} / \mathrm{L}$. The ferrous iron test kit follows the phenanthroline method with a $0-6 \mathrm{mg} / \mathrm{L}$ range; expected accuracy is $<0.08 \mathrm{mg} / \mathrm{L}$ at $0 \mathrm{mg} / \mathrm{L}, \pm 30 \%$ at 0.3 $\mathrm{mg} / \mathrm{L}, \pm 20 \%$ at $1.5 \mathrm{mg} / \mathrm{L}$, and $\pm 10 \%$ at $4.5 \mathrm{mg} / \mathrm{L}$. The sulfate test kit follows the turbidimetric method with a $0-100 \mathrm{mg} / \mathrm{L}$ range; expected accuracy is $\pm 30 \%$ at $10 \mathrm{mg} / \mathrm{L}$, $\pm 20 \%$ at $25 \mathrm{mg} / \mathrm{L}$, and $\pm 15 \%$ at $75 \mathrm{mg} / \mathrm{L}$.

Concentrations of total metals were measured by inductively coupled plasma optical emission spectrometry (ICP-OES) at KGS. A 250-mL TraceClean ${ }^{\mathrm{TM}}$ HDPE bottle was collected and preserved in the field with concentrated nitric acid. If the turbidity before sampling was $>10$ NTU, an extra bottle was collected and analyzed after being filtered through a $0.45-\mu \mathrm{m}$ filter in the field. Concentrations of inorganic anions $\left(\mathrm{Br}^{-}, \mathrm{Cl}^{-}, \mathrm{F}^{-}, \mathrm{NO}_{3}^{-}\right.$ $-\mathrm{N}$, and $\mathrm{SO}_{4}{ }^{2-}$ ) were measured by ion chromatography at KGS. A subset of samples was also analyzed for some inorganic $\left(\mathrm{F}^{-}, \mathrm{NO}_{3}{ }^{-}, \mathrm{PO}_{4}{ }^{3-}, \mathrm{SO}_{4}{ }^{2-}\right)$ and organic (acetate, formate and oxalate) anions in the University of Kentucky Department of Plant and Soil Sciences. DIC concentration was measured at KGS. Alkalinity was measured by acid titration in the lab following method EPA 310.1. A bulk sample collected in a 100-mL TraceClean ${ }^{\mathrm{TM}} \mathrm{HDPE}$ bottle was used for anion and alkalinity analyses.

Four 40-mL, crimp-top, borosilicate-glass bottles with bromobutyl rubber stoppers were collected for analysis of dissolved gases. Dissolved methane, ethane and propane 
concentrations were measured using an SRI 8610C gas chromatograph (GC) equipped with a flame ionization detector (FID) at KGS. Headspace was generated in the laboratory by displacing $\sim 10 \%$ of water with high-purity ( $99.999 \%$ pure) helium. Samples were agitated and allowed to equilibrate with the headspace for at least 1 hour before analyzing.

\subsection{Isotopic Analysis}

Samples for gas isotopic analyses were collected in the same manner as for dissolved gas concentration analyses. Unpreserved samples were collected for all water wells, and samples from the third sampling trip were also preserved with $\mathrm{HCl}$ or benzalkonium chloride. After attaining equilibrium, the headspace was injected onto a GC column where the gaseous components were separated, combusted or pyrolyzed, and measured. The $\delta^{13} \mathrm{C}$ and $\delta^{2} \mathrm{H}$ of dissolved $\mathrm{CH}_{4}$ were determined using a Thermo Trace GC IsoLink interfaced with a Thermo MAT 253 isotope ratio mass spectrometer (IRMS). Gas samples were introduced via manual injection into the internal volume of a Valco 6-port valve with fixed volume loops. A 30-m $\times 0.32$ i.d. Carboxen 1010 PLOT GC column was used for gas separation. Additionally, a subset of samples was collected in IsoFlask ${ }^{\mathrm{TM}}$ sample containers and analyzed by Isotech.

Sample collection for ${ }^{34} \mathrm{~S}^{-\mathrm{SO}_{4}}$ analysis followed Carmody et al. (1998) except samples with $\mathrm{SO}_{4}{ }^{2-}$ concentrations $<20 \mathrm{mg} / \mathrm{L}$ were also collected in 1-L bottles. Samples were filtered through a $0.45-\mu \mathrm{m}$ filter in the field and then allowed to react by adding a $\mathrm{BaCl}_{2}-\mathrm{HCl}$ solution. After $\sim 5$ minutes, the samples were filtered through $0.45-\mu \mathrm{m}$ filters and the filters and precipitates were stored. $\mathrm{The} \mathrm{BaSO}_{4}$ precipitate was oven-dried at $\sim 50^{\circ} \mathrm{C}$ overnight and analyzed for $\delta^{18} \mathrm{O}-\mathrm{SO}_{4}$ (using a Thermo TC/EA and DELTA ${ }^{\text {plus }} \mathrm{XP}$ isotope- 
ratio mass spectrometer [IRMS]) and $\delta^{34} \mathrm{~S}_{-} \mathrm{SO}_{4}$ (using a Thermo EA Isolink and MAT 253) at the Kentucky Stable Isotope Geochemistry Laboratory (KSIGL).

One 20-mL amber-glass bottle was collected for analysis of $\delta^{13} C$-DIC and $\delta^{13} C$ DOC in zero-headspace vials. $\delta^{13} C$-DIC was measured following methods in Torres et al. (2005). Samples were injected into autosampler vials filled with ultra-high purity $(99.999 \%$ pure) helium and reacted with phosphoric acid $\left(\mathrm{H}_{3} \mathrm{PO}_{4}\right)$. The reaction with DIC releases $\mathrm{CO}_{2}$, which is then injected into the system for isotopic characterization. $\delta^{13} C$-DOC was measured following methods described in Wilson et al. (2020), modified from Lang et al. (2012) and Zhou et al. (2015). DOC was oxidized to $\mathrm{CO}_{2}$, through the reaction with sodium persulfate. Both $\delta^{13} C$-DIC and $\delta^{13} C$-DOC were analyzed using a Thermo Finnigan GasBench II and DELTA ${ }^{\text {plus }}$ XP IRMS at KSIGL.

Samples for $\delta^{18} O$ and $\delta^{2} H$ were collected in the field through $0.45-\mu \mathrm{m}$ filters into zero-headspace $20-\mathrm{mL}$ plastic bottles. $\delta^{2} H$ and $\delta^{18} O$ in water were measured by isotoperatio infrared spectroscopy using a Los Gatos Research T-LWIA-45-EP at KSIGL.

2.4 Quality Assurance/Quality Control

Stable isotope ratios are reported in standard $\delta$-notation in units per mil (\%o) relative to VPDB (Vienna Peedee Belemnite) for $\delta^{13} C$ values, VCDT (Vienna Canyon Diablo Troilite) for $\delta^{34} S$ values, and VSMOW (Vienna Standard Mean Ocean Water) for $\delta^{2} H$ and $\delta^{18} \mathrm{O}$ values.

Field blanks and replicates were collected for all analyses at least once per sampling trip, resulting in at least one per 10 samples. Descriptive measures such as mean and median values and inferential measures such as confidence intervals were used to assess variability in the environmental samples. Moreover, the associations between methane 
concentrations and water chemistry were further explored with box-and-whisker plots and Spearman's rank correlation. Spearman's correlation coefficient $\rho$ was chosen to measure the degree of association between pairs of variables because it is a non-parametric correlation method not affected by the distribution of the data.

\section{RESULTS}

\subsection{Water Chemistry}

\subsubsection{Field Parameters}

Apart from temperature, field parameters varied over relatively broad ranges (Table 1). Temperature ranged from $12.6^{\circ} \mathrm{C}$ to $16.1^{\circ} \mathrm{C}$ (median $14.7^{\circ} \mathrm{C}$ ), $\mathrm{SC}$ from $48.6 \mu \mathrm{S} / \mathrm{cm}$ to $1287 \mu \mathrm{S} / \mathrm{cm}$ (median $459.3 \mu \mathrm{S} / \mathrm{cm}$ ), Eh from $22 \mathrm{mV}$ to $382 \mathrm{mV}$ (median $186.5 \mathrm{mV}$ ), DO from $0.15 \mathrm{mg} / \mathrm{L}$ to $8.1 \mathrm{mg} / \mathrm{L}$ (median $0.5 \mathrm{mg} / \mathrm{L}$ ), and $\mathrm{pH}$ from 5.32 to 9.01 (median 6.5). Eh values were adjusted relative to the standard $\mathrm{H}$ electrode from observed ORP following Wood (1976). Turbidity ranged from 1 NTU to 130 NTU (median 5 NTU), although only five samples were above $10 \mathrm{NTU}$. Alkalinity measured in the field ranged from 8.9 to 272 $\mathrm{mg} / \mathrm{L}$ as $\mathrm{CaCO}_{3}$ (median $112 \mathrm{mg} / \mathrm{L}$ as $\mathrm{CaCO}_{3}$ ).

Table 1. Field parameters and sampling information of water wells

\begin{tabular}{lrrrrrrrr}
\hline \multirow{2}{*}{ Site ID } & Latitude & Longitude & $\begin{array}{r}\text { Sampling } \\
\text { Date }\end{array}$ & Temp & pH & SC & Eh & DO \\
\hline Units & DD & DD & m/d/yyyy & ${ }^{\circ} \mathrm{C}$ & $\mathrm{n} / \mathrm{a}$ & $\mu \mathrm{S} / \mathrm{cm}$ & $\mathrm{mV}$ & $\mathrm{mg} / \mathrm{L}$ \\
\hline $\mathrm{A} 01$ & 37.53504 & -82.66463 & $4 / 17 / 2019$ & 15.0 & 6.54 & 516 & 278 & 0.7 \\
$\mathrm{~A} 02$ & 37.63811 & -82.82655 & $4 / 17 / 2019$ & 15.4 & 6.53 & 553 & 171 & 1.98 \\
$\mathrm{~A} 03$ & 37.46925 & -82.91434 & $4 / 18 / 2019$ & 14.6 & 7.73 & 459 & 79 & 0.47 \\
$\mathrm{~A} 04$ & 37.46847 & -82.91301 & $4 / 18 / 2019$ & 13.7 & 6.76 & 352 & 216 & 0.54
\end{tabular}


Table 1. Field parameters and sampling information of water wells (cont.)

Site ID Latitude $\begin{array}{lrlllll}\text { Longitude } & \begin{array}{r}\text { Sampling } \\ \text { Date }\end{array} & \text { Temp } & \text { pH } & \text { SC } & \text { Eh } & \text { DO }\end{array}$

\begin{tabular}{|c|c|c|c|c|c|c|c|c|}
\hline Units & $\mathrm{DD}$ & $\mathrm{DD}$ & m/d/yyyy & ${ }^{\circ} \mathrm{C}$ & $\mathrm{n} / \mathrm{a}$ & $\mu \mathrm{S} / \mathrm{cm}$ & $\mathrm{mV}$ & $\mathrm{mg} / \mathrm{L}$ \\
\hline A05 & 37.48390 & -82.83305 & $4 / 18 / 2019$ & 15.7 & 7.36 & 1261 & 74 & 0.53 \\
\hline A06 & 37.56112 & -82.81756 & $4 / 19 / 2019$ & 13.8 & 6.49 & 415 & 353 & 4.77 \\
\hline A07 & 37.56459 & -82.79870 & $4 / 19 / 2019$ & 14.2 & 6.84 & 310 & 128 & 0.54 \\
\hline A08 & 37.44989 & -82.72532 & $4 / 22 / 2019$ & 14.9 & 5.32 & 49 & 382 & 5.58 \\
\hline A09 & 37.68989 & -82.76185 & $4 / 23 / 2019$ & 12.5 & 5.88 & 62 & 358 & 8.05 \\
\hline A 10 & 37.50522 & -82.77895 & $4 / 23 / 2019$ & 15.6 & 6.44 & 1129 & 187 & 0.43 \\
\hline A11 & 37.58085 & -82.86566 & $4 / 23 / 2019$ & 16.1 & 6.87 & 1145 & 93 & 0.3 \\
\hline A12 & 37.46455 & -82.91467 & $4 / 24 / 2019$ & 12.6 & 5.48 & 74 & 370 & 7.67 \\
\hline A 13 & 37.31510 & -82.93391 & $4 / 29 / 2019$ & 14.4 & 9.01 & 985 & 22 & 0.25 \\
\hline A14 & 37.35790 & -82.98955 & $4 / 30 / 2019$ & 14.2 & 6.49 & 463 & 144 & 0.45 \\
\hline A15 & 37.38018 & -82.97216 & $4 / 30 / 2019$ & 15.6 & 5.94 & 207 & 225 & 0.26 \\
\hline A16 & 37.35752 & -82.91108 & $4 / 30 / 2019$ & 15.3 & 6.43 & 223 & 207 & 0.4 \\
\hline A17 & 37.37225 & -82.93622 & $5 / 1 / 2019$ & 14.5 & 6.3 & 187 & 329 & 1.17 \\
\hline A18 & 37.70234 & -83.08558 & $5 / 1 / 2$ & 14.4 & 6.36 & 406 & 209 & 0.54 \\
\hline A19 & 37.76513 & -83.15900 & $10 / 28 / 2019$ & 14.8 & 6.61 & 355 & 206 & 1.81 \\
\hline A02B & 37.63811 & -82.82655 & $10 / 28 / 2019$ & 15.1 & 6.5 & 551 & 161 & 2.34 \\
\hline A13B & 37.31510 & -82.93391 & $10 / 29 / 2019$ & 14.1 & 8.87 & 1078 & 41 & 0.2 \\
\hline A 20 & 37.31557 & -82.93404 & $10 / 29 / 2019$ & 15.1 & 8.76 & 868 & 35 & 0.15 \\
\hline A21 & 37.31561 & -83.10973 & $10 / 29 / 2019$ & 14.1 & 7.42 & 593 & 339 & 0.28 \\
\hline $\mathrm{A} 22$ & 37.39641 & -82.90697 & $10 / 30 / 2019$ & 14.2 & 6.49 & 274 & 122 & 0.3 \\
\hline A 23 & 37.26196 & -82.93532 & $10 / 30 / 2019$ & 14.7 & 6.34 & 221 & 329 & 4.71 \\
\hline A24 & 37.32885 & -83.01457 & $10 / 30 / 2019$ & 15.1 & 7.44 & 828 & 107 & 0.21 \\
\hline $\mathrm{A} 05 \mathrm{~B}$ & 37.48390 & -82.83305 & $10 / 31 / 2019$ & 15.7 & 7.45 & 1287 & 122 & 0.26 \\
\hline
\end{tabular}


Table 1. Field parameters and sampling information of water wells (cont.)

\begin{tabular}{|c|c|c|c|c|c|c|c|c|}
\hline Site ID & Turbidity & $\begin{array}{r}\text { Field } \\
\text { Alk. as } \\
\mathrm{CaCO}_{3}\end{array}$ & $\begin{array}{r}\mathrm{Lab} \\
\text { Alk. as } \\
\mathrm{CaCO}_{3}\end{array}$ & $\begin{array}{c}\text { Field } \\
\mathrm{Fe}^{2+}\end{array}$ & $\begin{array}{r}\text { Field } \\
\mathrm{S}^{2-}\end{array}$ & $\begin{array}{l}\text { Field } \\
\mathrm{SO}_{4}{ }^{2-}\end{array}$ & $\begin{array}{l}\text { Total } \\
\text { Depth }\end{array}$ & $\begin{array}{r}\text { Water } \\
\text { Use }\end{array}$ \\
\hline Units & NTU & $\mathrm{mg} / \mathrm{L}$ & $\mathrm{mg} / \mathrm{L}$ & $\mathrm{mg} / \mathrm{L}$ & $\mathrm{mg} / \mathrm{L}$ & $\mathrm{mg} / \mathrm{L}$ & $\mathrm{m}$ & $\mathrm{n} / \mathrm{a}$ \\
\hline A01 & 5 & 202 & 212 & 0.20 & 0.23 & - & - & $\begin{array}{r}\text { Domestic } \\
\text { primary }\end{array}$ \\
\hline A02 & 7 & 104 & 130 & $>6$ & 0.04 & - & 19.8 & None \\
\hline A03 & 2 & 167 & 182 & 0.03 & 0.17 & - & - & None \\
\hline A04 & 2 & 112 & 125 & 0.00 & 0.11 & - & - & $\begin{array}{c}\text { Domestic } \\
\text { primary }\end{array}$ \\
\hline A05 & 3 & 253 & 289 & 1.80 & 0.17 & - & $<8$ & $\begin{array}{l}\text { Domestic } \\
\text { secondary }\end{array}$ \\
\hline A06 & 28 & 92 & 151 & 0.06 & 0.09 & - & - & $\begin{array}{r}\text { Domestic } \\
\text { primary }\end{array}$ \\
\hline A07 & 1 & 42 & 153 & 1.41 & 0.09 & - & - & $\begin{array}{r}\text { Domestic } \\
\text { primary }\end{array}$ \\
\hline A08 & 6 & 8.9 & 15 & 0.04 & 0.18 & 10.0 & 4.5 & Gardening \\
\hline A09 & 8 & 14.4 & 16 & 0.10 & 0.20 & 19.7 & 7.0 & None \\
\hline A10 & 7 & 76 & 50 & $>6$ & 0.19 & $>100$ & 10.5 & None \\
\hline A11 & 130 & 223 & 164 & $>6$ & 0.03 & 14.8 & 18.3 & None \\
\hline A12 & 7 & 24.4 & 24 & 0.14 & 0.15 & 18.7 & 2.3 & None \\
\hline A13 & 4 & 272 & 462 & 0.16 & 0.04 & 2.8 & $\sim 40-60$ & $\begin{array}{r}\text { Domestic } \\
\text { primary }\end{array}$ \\
\hline A14 & 1 & 155 & 144 & $>6$ & 0.16 & 12.4 & - & $\begin{array}{r}\text { Domestic } \\
\text { primary }\end{array}$ \\
\hline A 15 & 8 & 87 & 61 & $>6$ & 0.28 & 29.5 & - & $\begin{array}{r}\text { Industrial } \\
\text { primary }\end{array}$ \\
\hline A16 & 16 & 103 & 111 & 0.72 & 0.07 & 22.3 & - & $\begin{array}{r}\text { Domestic } \\
\text { primary }\end{array}$ \\
\hline A17 & 12 & 72 & 89 & 0.30 & 0.14 & 13.8 & - & $\begin{array}{c}\text { Domestic } \\
\text { primary }\end{array}$ \\
\hline A18 & 8 & 180 & 169 & 3.95 & 0.22 & 25.5 & 30.5 & Gardening \\
\hline A19 & 20 & 170 & 182 & 0.50 & 0.42 & 17.9 & $<8$ & Gardening \\
\hline A02B & 4 & 85 & 105 & $>6$ & 0.35 & 2.9 & (above) & (above) \\
\hline A13B & 1 & 246 & 358 & 0.12 & 0.48 & 1.5 & (above) & (above) \\
\hline A 20 & 6 & 254 & 336 & 0.00 & 0.54 & 1.5 & - & $\begin{array}{r}\text { Domestic } \\
\text { primary }\end{array}$ \\
\hline A21 & 3 & 167 & 247 & 0.11 & 0.41 & 0.6 & - & $\begin{array}{c}\text { Domestic } \\
\text { primary }\end{array}$ \\
\hline
\end{tabular}


Table 1. Field parameters and sampling information of water wells (cont.)

\begin{tabular}{|c|c|c|c|c|c|c|c|c|}
\hline Site ID & Turbidity & $\begin{array}{l}\text { Field } \\
\text { Alk. as } \\
\mathrm{CaCO}_{3}\end{array}$ & $\begin{array}{r}\mathrm{Lab} \\
\mathrm{Alk} \text { as } \\
\mathrm{CaCO}_{3}\end{array}$ & $\begin{array}{l}\text { Field } \\
\mathrm{Fe}^{2+}\end{array}$ & $\begin{array}{l}\text { Field } \\
\mathrm{S}^{2-}\end{array}$ & $\begin{array}{l}\text { Field } \\
\mathrm{SO}_{4}^{2-}\end{array}$ & $\begin{array}{l}\text { Total } \\
\text { Depth }\end{array}$ & $\begin{array}{l}\text { Water } \\
\text { Use }\end{array}$ \\
\hline Units & NTU & $\mathrm{mg} / \mathrm{L}$ & $\mathrm{mg} / \mathrm{L}$ & $\mathrm{mg} / \mathrm{L}$ & $\mathrm{mg} / \mathrm{L}$ & $\mathrm{mg} / \mathrm{L}$ & $\mathrm{m}$ & $\mathrm{n} / \mathrm{a}$ \\
\hline A22 & 2 & 53 & 87 & $>6$ & 0.37 & 0.2 & - & $\begin{array}{r}\text { Domestic } \\
\text { primary }\end{array}$ \\
\hline A23 & 1 & 55 & 56 & 0.02 & 0.37 & 50.4 & $\sim 91$ & $\begin{array}{l}\text { Domestic } \\
\text { primary }\end{array}$ \\
\hline A24 & 2 & 226 & 293 & $<0$ & 0.37 & $<0$ & - & $\begin{array}{l}\text { Domestic } \\
\text { secondary }\end{array}$ \\
\hline A05B & 3 & 162 & 282 & 0.00 & 0.53 & 0.0 & (above) & (above) \\
\hline tes: & & & ta & & & & & \\
\hline
\end{tabular}

Dissolved $\mathrm{Fe}^{2+}$ concentrations measured in the field were over the measurable range $(>6 \mathrm{mg} / \mathrm{L}$ ) in six wells and the remaining 18 wells ranged from 0.0 to $4.0 \mathrm{mg} / \mathrm{L}$ (median $0.1 \mathrm{mg} / \mathrm{L}$ ). Sulfide concentrations were below $0.3 \mathrm{mg} / \mathrm{L}$ for all samples collected in May but ranged from 0.3 to $0.5 \mathrm{mg} / \mathrm{L}$ in samples collected in November. Sulfate concentrations ranged from 0 to $50 \mathrm{mg} / \mathrm{L}$ (median $13.1 \mathrm{mg} / \mathrm{L}$ ) and one sample measured $>100 \mathrm{mg} / \mathrm{L}$.

Water depths were known for seven of the wells and ranged from $7.6 \mathrm{ft}$ to $100 \mathrm{ft}$ (2.3-30.5 m) (median $34.6 \mathrm{ft}(10.5 \mathrm{~m})$ ), two wells had estimated depths between 200-300 $\mathrm{ft}(60-90 \mathrm{~m})$, and one well was estimated $<25 \mathrm{ft}(<7.6 \mathrm{~m})$. Thirteen water wells were actively used by their residents as primary drinking water sources, six wells were not currently in use, three wells were used for gardening, and two were used as secondary water sources not for consumption.

\subsubsection{Total Metals and Anions}

Concentrations of major cations $\left(\mathrm{Ca}^{2+}, \mathrm{Mg}^{2+}, \mathrm{Na}^{+}, \mathrm{K}^{+}\right)$and anions $\left(\mathrm{HCO}_{3}^{-}, \mathrm{Cl}^{-}\right.$, $\mathrm{SO}_{4}{ }^{2-}$ ) are shown in Table 2. Concentrations of minor metals ( $\mathrm{Al}, \mathrm{Ba}, \mathrm{Cr}, \mathrm{Co}, \mathrm{Cu}, \mathrm{Fe}, \mathrm{Pb}$, Li, Mn, Ni, Sr, V, Zn) and metalloids (B, Si, As) are shown in Table 3, and concentrations 
of minor anions $\left(\mathrm{Br}^{-}, \mathrm{F}^{-}, \mathrm{NO}_{3}-\mathrm{N}\right.$, acetate) are shown in Table 4. Bicarbonate $\left(\mathrm{HCO}_{3}^{-}\right)$ concentrations were calculated by multiplying field alkalinity as $\mathrm{CaCO}_{3}$ by 1.22 and assume that all alkalinity is present as $\mathrm{HCO}_{3}^{-}$in the $\mathrm{pH}$ range observed. Formate and oxalate concentrations were below the detection limit or similar to field blanks and are not shown. No major differences were seen in the two samples collected after treatment systems, one after a water softener (A04), and another one after a sulfate filter (A23). Sample A04 had close to no calcium and magnesium, whereas sample A23 still had sulfate. Hand-dug wells (A08, A09 and A12) had the lowest TDS values. The milliequivalent concentrations of major ions were used to determine water type using a Piper diagram (Deutsch, 1997) (Figure 3). The most prominent water type is $\mathrm{Ca}-\mathrm{HCO}_{3}(\mathrm{n}=7)$, followed by $\mathrm{Na}-\mathrm{HCO}_{3}(n=5), \mathrm{Ca}_{-} \mathrm{HCO}_{3}-\mathrm{Cl}(n=4), \mathrm{Na}-\mathrm{HCO}_{3}-\mathrm{Cl}(\mathrm{n}=3), \mathrm{Ca}-\mathrm{Na}-\mathrm{HCO}_{3}(\mathrm{n}=3), \mathrm{Ca}-\mathrm{Na}-$ $\mathrm{HCO}_{3}-\mathrm{Cl}(\mathrm{n}=1)$, and $\mathrm{Ca}-\mathrm{Cl}(\mathrm{n}=1)$. 
Table 2. Concentrations of major cations and anions in water wells

\begin{tabular}{|c|c|c|c|c|c|c|c|c|}
\hline Site ID & $\mathrm{Ca}^{2+}$ & $\mathrm{Mg}^{2+}$ & $\mathrm{Na}^{1+}$ & $\mathrm{K}^{+}$ & $\mathrm{Cl}^{-}$ & $\mathrm{Br}^{-}$ & $\mathrm{HCO}_{3}^{-}$ & $\mathrm{SO}_{4}{ }^{2-}$ \\
\hline Units & $\mathrm{mg} / \mathrm{L}$ & $\mathrm{mg} / \mathrm{L}$ & $\mathrm{mg} / \mathrm{L}$ & $\mathrm{mg} / \mathrm{L}$ & $\mathrm{mg} / \mathrm{L}$ & $\mathrm{mg} / \mathrm{L}$ & $\mathrm{mg} / \mathrm{L}$ & $\mathrm{mg} / \mathrm{L}$ \\
\hline MDL & 0.002 & 0.001 & 0.058 & 0.191 & 1.0 & 0.1 & 1.5 & 5.00 \\
\hline RL & 0.006 & 0.003 & 0.032 & 0.035 & 0.076 & 0.003 & 4.77 & 0.045 \\
\hline $\begin{array}{l}\text { NPDWR, } \\
\text { NSDWR }\end{array}$ & $\begin{array}{l}\mathrm{n} / \mathrm{a}, \\
\mathrm{n} / \mathrm{a}\end{array}$ & $\begin{array}{r}\mathrm{n} / \mathrm{a}, \\
\mathrm{n} / \mathrm{a}\end{array}$ & $\begin{array}{l}\mathrm{n} / \mathrm{a}, \\
\mathrm{n} / \mathrm{a}\end{array}$ & $\begin{array}{l}\mathrm{n} / \mathrm{a}, \\
\mathrm{n} / \mathrm{a}\end{array}$ & $\begin{array}{l}\mathrm{n} / \mathrm{a}, \\
250\end{array}$ & $\begin{array}{l}\mathrm{n} / \mathrm{a}, \\
\mathrm{n} / \mathrm{a}\end{array}$ & $\begin{array}{l}\mathrm{n} / \mathrm{a}, \\
\mathrm{n} / \mathrm{a}\end{array}$ & $\begin{array}{l}\mathrm{n} / \mathrm{a}, \\
250\end{array}$ \\
\hline A01 & 55.2 & 20.5 & 28.4 & 2.71 & 7.53 & $<\mathrm{MDL}$ & 246.44 & 69.7 \\
\hline A02 & 29.6 & 4.53 & 69.1 & 2.73 & 103 & 0.39 & 126.88 & $<\mathrm{MDL}$ \\
\hline A03 & 16.9 & 4.2 & 78.4 & 2.62 & 40.1 & $<\mathrm{MDL}$ & 203.74 & $<\mathrm{MDL}$ \\
\hline A04 & 0.03 & $<\mathrm{MDL}$ & 82.4 & 0.32 & 11.1 & $<\mathrm{MDL}$ & 136.64 & 49 \\
\hline A05 & 37.1 & 12.4 & 199 & 3.15 & 212 & 0.54 & 308.66 & $<\mathrm{MDL}$ \\
\hline A06 & 53.4 & 8.96 & 23.6 & 2.07 & 1.95 & $<\mathrm{MDL}$ & 112.24 & 74.2 \\
\hline A07 & 32.4 & 10.8 & 17.7 & 2.48 & 9.35 & $<\mathrm{MDL}$ & 186.66 & $<\mathrm{MDL}$ \\
\hline A08 & 4.84 & 1.93 & 1.37 & 1.78 & $<\mathrm{MDL}$ & $<\mathrm{MDL}$ & 10.86 & 5.4 \\
\hline A09 & 6 & 2.92 & 1.92 & 1.03 & $<\mathrm{MDL}$ & $<\mathrm{MDL}$ & 17.57 & 13.8 \\
\hline A10 & 102 & 52.9 & 39.9 & 5.18 & 1.61 & $<\mathrm{MDL}$ & 92.72 & 566 \\
\hline A11 & 62.2 & 23.2 & 141 & 4.99 & 268 & 0.68 & 272.06 & 5.79 \\
\hline A12 & 6.39 & 2.76 & 2.01 & 4.67 & 1.02 & $<\mathrm{MDL}$ & 29.77 & 12.5 \\
\hline A13 & 0.92 & 0.2 & 223 & 1.74 & 114 & $<\mathrm{MDL}$ & 331.84 & $<\mathrm{MDL}$ \\
\hline A14 & 45.7 & 9.11 & 24.9 & 2.18 & 42.9 & $<\mathrm{MDL}$ & 189.10 & 10.7 \\
\hline A15 & 18.1 & 6.19 & 7.58 & 1.41 & 9.7 & $<\mathrm{MDL}$ & 106.14 & 24.7 \\
\hline A16 & 28.1 & 5.48 & 11 & 1.96 & 2.65 & $<\mathrm{MDL}$ & 125.66 & 8.33 \\
\hline A17 & 21.7 & 7.27 & 5.86 & 2.2 & 1.32 & $<\mathrm{MDL}$ & 87.84 & 10.4 \\
\hline A18 & 30.9 & 16.3 & 28 & 2.89 & 13.1 & $<\mathrm{MDL}$ & 219.60 & 20.3 \\
\hline A19 & 31.1 & 10.7 & 28.9 & 2.55 & 1.8 & $<\mathrm{MDL}$ & 207.40 & 10.561 \\
\hline A02B & 27.5 & 4.09 & 63.6 & 2.67 & 101 & 0.34 & 103.70 & 0.56 \\
\hline A13B & 1.01 & 0.21 & 217 & 2.07 & 134 & 0.17 & 300.12 & 0.493 \\
\hline A 20 & 0.85 & 0.16 & 182 & 1.53 & 67.8 & $<\mathrm{MDL}$ & 309.88 & 2.915 \\
\hline A21 & 7.67 & 0.32 & 119 & 1.45 & 39 & $<\mathrm{MDL}$ & 203.74 & 0.559 \\
\hline A22 & 15.9 & 4.81 & 15.6 & 1.39 & 19.5 & $<\mathrm{MDL}$ & 64.66 & 1.674 \\
\hline A23 & 18.8 & 9.22 & 6.11 & 3.23 & 1.33 & $<\mathrm{MDL}$ & 67.10 & 52.038 \\
\hline A24 & 28.5 & 7.675 & 183.5 & 3.115 & 165.5 & 0.27 & 275.72 & 0.763 \\
\hline A05B & 0.06 & 0.01 & 245 & 0.65 & 215 & 0.67 & 197.64 & 0.474 \\
\hline otes: & $\mathrm{M}$ & $\begin{array}{l}\text { WR } \\
\text { WR }\end{array}$ & $\begin{array}{l}\text { Meth } \\
\text { Repo } \\
\text { Natio } \\
\text { Natio } \\
\text { Conce }\end{array}$ & Detec & Ion Limit & NPD & or $\mathrm{N}$ & $\begin{array}{l}\text { ls } \\
\text { ion } \\
\text { ion }\end{array}$ \\
\hline
\end{tabular}


Table 3. Concentrations of minor metals and metalloids in water wells

\begin{tabular}{|c|c|c|c|c|c|c|c|c|}
\hline Site ID & $\mathrm{Al}$ & As & B & $\mathrm{Ba}$ & $\mathrm{Cr}$ & $\mathrm{Co}$ & $\mathrm{Cu}$ & 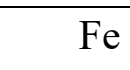 \\
\hline Units & $\mathrm{mg} / \mathrm{L}$ & $\mathrm{mg} / \mathrm{L}$ & $\mathrm{mg} / \mathrm{L}$ & $\mathrm{mg} / \mathrm{L}$ & $\mathrm{mg} / \mathrm{L}$ & $\mathrm{mg} / \mathrm{L}$ & $\mathrm{mg} / \mathrm{L}$ & $\mathrm{mg} / \mathrm{L}$ \\
\hline MDL & 0.061 & 0.014 & 0.008 & 0.003 & 0.024 & 0.001 & 0.005 & 0.002 \\
\hline RL & 0.194 & 0.045 & 0.025 & 0.010 & 0.076 & 0.003 & 0.016 & 0.006 \\
\hline $\begin{array}{l}\text { NPDWR, } \\
\text { NSDWR }\end{array}$ & $\begin{array}{r}\mathrm{n} / \mathrm{a}, \\
0.2\end{array}$ & $\begin{array}{r}0.01, \\
\mathrm{n} / \mathrm{a}\end{array}$ & $\begin{array}{r}\mathrm{n} / \mathrm{a}, \\
\mathrm{n} / \mathrm{a}\end{array}$ & $\begin{array}{r}2.0 \\
\mathrm{n} / \mathrm{a}\end{array}$ & $\begin{array}{r}0.10, \\
\mathrm{n} / \mathrm{a}\end{array}$ & $\begin{array}{l}\mathrm{n} / \mathrm{a}, \\
\mathrm{n} / \mathrm{a}\end{array}$ & $\begin{array}{l}1.3, \\
1.0\end{array}$ & $\begin{array}{r}\mathrm{n} / \mathrm{a}, \\
0.30\end{array}$ \\
\hline A01 & MDL & $<\mathrm{MDL}$ & 0.03 & 0.47 & $<\mathrm{MDL}$ & $<\mathrm{MDL}$ & $<\mathrm{MDL}$ & 0.9 \\
\hline A 02 & MDL & 0.05 & 0.05 & 0.16 & $<\mathrm{MDL}$ & $<\mathrm{MDL}$ & $<\mathrm{MDL}$ & 8.67 \\
\hline A03 & MDL & $<\mathrm{MDL}$ & 0.05 & 0.67 & $<\mathrm{MDL}$ & $<\mathrm{MDL}$ & $<\mathrm{MDL}$ & $<\mathrm{MDL}$ \\
\hline A04 & MDL & $<\mathrm{MDL}$ & $<\mathrm{MDL}$ & $<\mathrm{MDL}$ & $<\mathrm{MDL}$ & $<\mathrm{MDL}$ & $<\mathrm{MDL}$ & $<\mathrm{MDL}$ \\
\hline A05 & MDL & $<\mathrm{MDL}$ & 0.08 & 0.79 & $<\mathrm{MDL}$ & $<\mathrm{MDL}$ & $<\mathrm{MDL}$ & 2.11 \\
\hline A06 & 0.4 & $<\mathrm{MDL}$ & 0.014 & 0.06 & $<\mathrm{MDL}$ & $<\mathrm{MDL}$ & 0.02 & 0.66 \\
\hline $\mathrm{A} 07$ & MDL & $<\mathrm{MDL}$ & 0.05 & 0.43 & $<\mathrm{MDL}$ & $<\mathrm{MDL}$ & $<\mathrm{MDL}$ & 1.57 \\
\hline A08 & 0.15 & $<\mathrm{MDL}$ & 0.04 & 0.02 & $<\mathrm{MDL}$ & $<\mathrm{MDL}$ & $<\mathrm{MDL}$ & 0.04 \\
\hline A09 & 0.3 & $<\mathrm{MDL}$ & 0.1 & 0.02 & $<\mathrm{MDL}$ & $<\mathrm{MDL}$ & $<\mathrm{MDL}$ & 0.18 \\
\hline A 10 & 0.17 & $<\mathrm{MDL}$ & 0.09 & 0.04 & $<\mathrm{MDL}$ & $<\mathrm{MDL}$ & 0.005 & 44.5 \\
\hline A11 & MDL & $<\mathrm{MDL}$ & 0.05 & 1.66 & $<\mathrm{MDL}$ & $<\mathrm{MDL}$ & $<\mathrm{MDL}$ & 9.62 \\
\hline A12 & 0.34 & $<\mathrm{MDL}$ & 0.02 & 0.04 & $<\mathrm{MDL}$ & $<\mathrm{MDL}$ & $<\mathrm{MDL}$ & 0.37 \\
\hline A13 & MDL & $<\mathrm{MDL}$ & 0.08 & 0.09 & $<\mathrm{MDL}$ & $<\mathrm{MDL}$ & $<\mathrm{MDL}$ & $<\mathrm{MDL}$ \\
\hline A14 & MDL & $<\mathrm{MDL}$ & 0.07 & 0.81 & $<\mathrm{MDL}$ & $<\mathrm{MDL}$ & $<\mathrm{MDL}$ & 11.9 \\
\hline A1 & MDL & $<\mathrm{MDL}$ & 3 & 0.06 & $<\mathrm{MDL}$ & $<\mathrm{MDL}$ & 0.01 & 8.12 \\
\hline A1 & IDL & $<\mathrm{MDL}$ & $<\mathrm{MDL}$ & 0.63 & $<\mathrm{MDL}$ & $<\mathrm{MDL}$ & $<\mathrm{MDL}$ & 7.88 \\
\hline A17 & 0.11 & $<\mathrm{MDL}$ & 0.04 & 0.18 & $<\mathrm{MDL}$ & $<\mathrm{MDL}$ & 0.02 & 0.08 \\
\hline Als & MDL & $<\mathrm{MDL}$ & 0.04 & 0.21 & $<\mathrm{MDL}$ & $<\mathrm{MDL}$ & 0.008 & 4.37 \\
\hline A19 & MDL & $<\mathrm{MDL}$ & 0.05 & 0.17 & $<\mathrm{MDL}$ & $<\mathrm{MDL}$ & $<\mathrm{MDL}$ & 2.2 \\
\hline $\mathrm{A} 02 \mathrm{~B}$ & MDL & 0.02 & $<\mathrm{MDL}$ & 0.16 & $<\mathrm{MDL}$ & $<\mathrm{MDL}$ & $<\mathrm{MDL}$ & 9.63 \\
\hline $\mathrm{A} 13 \mathrm{~B}$ & $<\mathrm{MDL}$ & $<\mathrm{MDL}$ & 0.1 & 0.09 & $<\mathrm{MDL}$ & $<\mathrm{MDL}$ & $<\mathrm{MDL}$ & $<\mathrm{MDL}$ \\
\hline A 20 & MDL & $<\mathrm{MDL}$ & 0.08 & 0.06 & $<\mathrm{MDL}$ & $<\mathrm{MDL}$ & $<\mathrm{MDL}$ & 0.01 \\
\hline A 21 & MDL & $<\mathrm{MDL}$ & 0.0 & 0.09 & $<\mathrm{MDL}$ & $<\mathrm{MDL}$ & 0.01 & 0.15 \\
\hline A 22 & DL & $<\mathrm{MDL}$ & & 0.24 & $<\mathrm{MDL}$ & $<\mathrm{MDL}$ & $<\mathrm{MDL}$ & 19.3 \\
\hline A23 & IDL & $<$ MDL & 0.03 & 0.06 & $<\mathrm{MDL}$ & $<\mathrm{MDL}$ & $<\mathrm{MDL}$ & $<\mathrm{MDL}$ \\
\hline A24 & MDL & $<\mathrm{MDL}$ & 0.055 & 1.075 & $<\mathrm{MDL}$ & $<\mathrm{MDL}$ & $<\mathrm{MDL}$ & 0.35 \\
\hline A05B & $<\mathrm{MDL}$ & $<\mathrm{MDL}$ & 0.07 & $<\mathrm{MDL}$ & $<\mathrm{MDL}$ & $<\mathrm{MDL}$ & $<\mathrm{MDL}$ & 0.11 \\
\hline
\end{tabular}


Table 3. Concentrations of minor metals and metalloids in water wells (cont.)

\begin{tabular}{|c|c|c|c|c|c|c|c|c|}
\hline Site ID & $\mathrm{Pb}$ & $\mathrm{Li}$ & $\mathrm{Mn}$ & $\mathrm{Ni}$ & $\mathrm{Si}$ & $\mathrm{Sr}$ & V & $\mathrm{Zn}$ \\
\hline Units & $\mathrm{mg} / \mathrm{L}$ & $\mathrm{mg} / \mathrm{L}$ & $\mathrm{mg} / \mathrm{L}$ & $\mathrm{mg} / \mathrm{L}$ & $\mathrm{mg} / \mathrm{L}$ & $\mathrm{mg} / \mathrm{L}$ & $\mathrm{mg} / \mathrm{L}$ & $\mathrm{mg} / \mathrm{L}$ \\
\hline MDL & 0.010 & 0.001 & 0.001 & 0.002 & 0.009 & 0.010 & 0.008 & 0.002 \\
\hline RL & 0.032 & 0.003 & 0.003 & 0.006 & 0.029 & 0.032 & 0.025 & 0.006 \\
\hline $\begin{array}{l}\text { NPDWR, } \\
\text { NSDWR }\end{array}$ & $\begin{array}{r}0.02, \\
\mathrm{n} / \mathrm{a}\end{array}$ & $\begin{array}{r}\mathrm{n} / \mathrm{a}, \\
\mathrm{n} / \mathrm{a}\end{array}$ & $\begin{array}{r}\mathrm{n} / \mathrm{a}, \\
0.050\end{array}$ & $\begin{array}{l}\mathrm{n} / \mathrm{a}, \\
\mathrm{n} / \mathrm{a}\end{array}$ & $\begin{array}{l}\mathrm{n} / \mathrm{a}, \\
\mathrm{n} / \mathrm{a}\end{array}$ & $\begin{array}{r}\mathrm{n} / \mathrm{a}, \\
\mathrm{n} / \mathrm{a}\end{array}$ & $\begin{array}{l}\mathrm{n} / \mathrm{a}, \\
\mathrm{n} / \mathrm{a}\end{array}$ & $\begin{array}{r}\mathrm{n} / \mathrm{a}, \\
5.0\end{array}$ \\
\hline A01 & $<\mathrm{MDL}$ & 0.02 & 0.49 & $<\mathrm{MDL}$ & 13.7 & 0.76 & $<\mathrm{MDL}$ & 0.02 \\
\hline A02 & $<\mathrm{MDL}$ & 0.004 & 0.19 & 0.006 & 10.4 & 0.26 & $<\mathrm{MDL}$ & 0.23 \\
\hline A03 & $<\mathrm{MDL}$ & 0.02 & 0.02 & $<\mathrm{MDL}$ & 7.94 & 0.92 & $<\mathrm{MDL}$ & $<\mathrm{MDL}$ \\
\hline A04 & $<\mathrm{MDL}$ & $<\mathrm{MDL}$ & $<\mathrm{MDL}$ & $<\mathrm{MDL}$ & 9.32 & $<\mathrm{MDL}$ & $<\mathrm{MDL}$ & 0.003 \\
\hline A05 & $<\mathrm{MDL}$ & 0.01 & 0.14 & $<\mathrm{MDL}$ & 6.87 & 0.85 & $<\mathrm{MDL}$ & 0.02 \\
\hline A06 & $<\mathrm{MDL}$ & 0.01 & 0.03 & 0.003 & 7.39 & 0.29 & $<\mathrm{MDL}$ & 0.02 \\
\hline A07 & $<\mathrm{MDL}$ & 0.01 & 0.15 & $<\mathrm{MDL}$ & 13.2 & 0.41 & $<\mathrm{MDL}$ & 0.002 \\
\hline A08 & $<\mathrm{MDL}$ & 0.004 & 0.007 & $<\mathrm{MDL}$ & 3.83 & 0.04 & $<\mathrm{MDL}$ & 0.04 \\
\hline A09 & $<\mathrm{MDL}$ & 0.001 & 0.004 & $<\mathrm{MDL}$ & 4.91 & 0.04 & $<\mathrm{MDL}$ & 0.008 \\
\hline A10 & $<\mathrm{MDL}$ & 0.006 & 2.13 & 0.005 & 8.45 & 0.78 & $<\mathrm{MDL}$ & 0.14 \\
\hline A11 & $<\mathrm{MDL}$ & 0.02 & 0.43 & $<\mathrm{MDL}$ & 7.16 & 1.52 & $<\mathrm{MDL}$ & 0.31 \\
\hline $\mathrm{A} 12$ & $<\mathrm{MDL}$ & 0.003 & 0.006 & $<\mathrm{MDL}$ & 5.44 & 0.04 & $<\mathrm{MDL}$ & 0.02 \\
\hline A13 & $<\mathrm{MDL}$ & 0.05 & 0.002 & $<\mathrm{MDL}$ & 4.62 & 0.1 & $<\mathrm{MDL}$ & $<\mathrm{MDL}$ \\
\hline A14 & $<\mathrm{MDL}$ & 0.01 & 0.33 & $<\mathrm{MDL}$ & 11.2 & 0.73 & $<\mathrm{MDL}$ & 0.003 \\
\hline A15 & $<\mathrm{MDL}$ & 0.003 & 0.78 & 0.005 & 9.39 & 0.09 & $<\mathrm{MDL}$ & 0.02 \\
\hline A16 & $<\mathrm{MDL}$ & 0.01 & 0.09 & $<\mathrm{MDL}$ & 11.9 & 0.61 & $<\mathrm{MDL}$ & 0.002 \\
\hline A17 & $<\mathrm{MDL}$ & 0.002 & 0.02 & 0.002 & 4.23 & 0.3 & $<\mathrm{MDL}$ & 0.03 \\
\hline A18 & $<\mathrm{MDL}$ & 0.01 & 0.43 & 0.003 & 8.83 & 0.23 & $<\mathrm{MDL}$ & 0.03 \\
\hline A19 & $<\mathrm{MDL}$ & 0.03 & 0.09 & $<\mathrm{MDL}$ & 9.33 & 0.23 & $<\mathrm{MDL}$ & 0.007 \\
\hline A02B & $<\mathrm{MDL}$ & 0.02 & 0.15 & $<\mathrm{MDL}$ & 11 & 0.24 & $<\mathrm{MDL}$ & 0.25 \\
\hline A13B & $<\mathrm{MDL}$ & 0.09 & 0.002 & $<\mathrm{MDL}$ & 3.95 & 0.11 & $<\mathrm{MDL}$ & $<\mathrm{MDL}$ \\
\hline A 20 & $<\mathrm{MDL}$ & 0.06 & 0.003 & $<\mathrm{MDL}$ & 4.14 & 0.07 & $<\mathrm{MDL}$ & 0.04 \\
\hline A21 & $<\mathrm{MDL}$ & 0.06 & 0.03 & $<\mathrm{MDL}$ & 5.8 & 0.2 & $<\mathrm{MDL}$ & 0.006 \\
\hline A22 & $<\mathrm{MDL}$ & 0.01 & 0.27 & $<\mathrm{MDL}$ & 10.3 & 0.15 & $<\mathrm{MDL}$ & 0.01 \\
\hline A23 & $<\mathrm{MDL}$ & 0.03 & 0.03 & $<\mathrm{MDL}$ & 4.9 & 0.64 & $<\mathrm{MDL}$ & 0.008 \\
\hline A24 & $<\mathrm{MDL}$ & 0.095 & 0.04 & $<\mathrm{MDL}$ & 7.68 & 1.06 & $<\mathrm{MDL}$ & 0.002 \\
\hline A05B & $<\mathrm{MDL}$ & 0.02 & $<\mathrm{MDL}$ & $<\mathrm{MDL}$ & 6.26 & $<\mathrm{MDL}$ & $<\mathrm{MDL}$ & 0.01 \\
\hline
\end{tabular}


Table 4. Concentrations of minor anions in water wells

\begin{tabular}{|c|c|c|c|c|}
\hline Site ID & $\mathrm{Br}^{-}$ & $\mathrm{F}^{-}$ & $\mathrm{NO}_{3}{ }^{-}-\mathrm{N}$ & Acetate \\
\hline Units & $\mathrm{mg} / \mathrm{L}$ & $\mathrm{mg} / \mathrm{L}$ & $\mathrm{mg} / \mathrm{L}$ & $\mathrm{mg} / \mathrm{L}$ \\
\hline MDL & 0.1 & 0.1 & 0.02 & 0.013 \\
\hline RL & 0.32 & 0.32 & 0.06 & - \\
\hline $\begin{array}{l}\text { NPDWR, } \\
\text { NSDWR }\end{array}$ & $\begin{array}{l}\mathrm{n} / \mathrm{a}, \\
\mathrm{n} / \mathrm{a}\end{array}$ & $\begin{array}{l}4.0, \\
2.0\end{array}$ & $\begin{array}{l}10, \\
\mathrm{n} / \mathrm{a}\end{array}$ & $\begin{array}{l}\mathrm{n} / \mathrm{a}, \\
\mathrm{n} / \mathrm{a}\end{array}$ \\
\hline A01 & $<\mathrm{MDL}$ & 0.23 & 0.032 & - \\
\hline A02 & 0.39 & 0.15 & $<\mathrm{MDL}$ & - \\
\hline A03 & $<\mathrm{MDL}$ & 0.33 & $<\mathrm{MDL}$ & - \\
\hline A04 & $<\mathrm{MDL}$ & $<\mathrm{MDL}$ & $<\mathrm{MDL}$ & - \\
\hline A05 & 0.54 & 0.1 & $<\mathrm{MDL}$ & - \\
\hline A06 & $<\mathrm{MDL}$ & 0.25 & $<\mathrm{MDL}$ & - \\
\hline A07 & $<\mathrm{MDL}$ & 0.28 & $<\mathrm{MDL}$ & - \\
\hline A08 & $<\mathrm{MDL}$ & $<\mathrm{MDL}$ & 2.87 & - \\
\hline A09 & $<\mathrm{MDL}$ & $<\mathrm{MDL}$ & 0.757 & - \\
\hline A10 & $<\mathrm{MDL}$ & $<\mathrm{MDL}$ & $<\mathrm{MDL}$ & - \\
\hline A11 & 0.68 & $<\mathrm{MDL}$ & $<\mathrm{MDL}$ & - \\
\hline A12 & $<\mathrm{MDL}$ & $<\mathrm{MDL}$ & 1.202 & - \\
\hline A13 & $<\mathrm{MDL}$ & 1.62 & $<\mathrm{MDL}$ & _- \\
\hline A14 & $<\mathrm{MDL}$ & 0.13 & $<\mathrm{MDL}$ & - \\
\hline A15 & $<\mathrm{MDL}$ & 0.13 & $<\mathrm{MDL}$ & - \\
\hline A16 & $<\mathrm{MDL}$ & 0.13 & 0.346 & - \\
\hline A17 & $<\mathrm{MDL}$ & $<\mathrm{MDL}$ & 0.14 & - \\
\hline A18 & $<\mathrm{MDL}$ & 0.16 & $<\mathrm{MDL}$ & - \\
\hline A19 & $<\mathrm{MDL}$ & 0.3 & $<\mathrm{MDL}$ & 0.31 \\
\hline $\mathrm{A} 02 \mathrm{~B}$ & 0.34 & 0.21 & $<\mathrm{MDL}$ & - \\
\hline A13B & 0.17 & 2.21 & $<\mathrm{MDL}$ & $<\mathrm{MDL}$ \\
\hline A20 & $<\mathrm{MDL}$ & 1.62 & $<\mathrm{MDL}$ & 0.25 \\
\hline A 21 & $<\mathrm{MDL}$ & 0.89 & $<\mathrm{MDL}$ & 0.34 \\
\hline A22 & $<\mathrm{MDL}$ & 0.18 & $<\mathrm{MDL}$ & - \\
\hline A23 & $<\mathrm{MDL}$ & 0.13 & 0.226 & 0.29 \\
\hline A24 & 0.27 & 0.95 & $<\mathrm{MDL}$ & $<\mathrm{MDL}$ \\
\hline A05B & 0.67 & 1.11 & $<\mathrm{MDL}$ & 0.22 \\
\hline
\end{tabular}




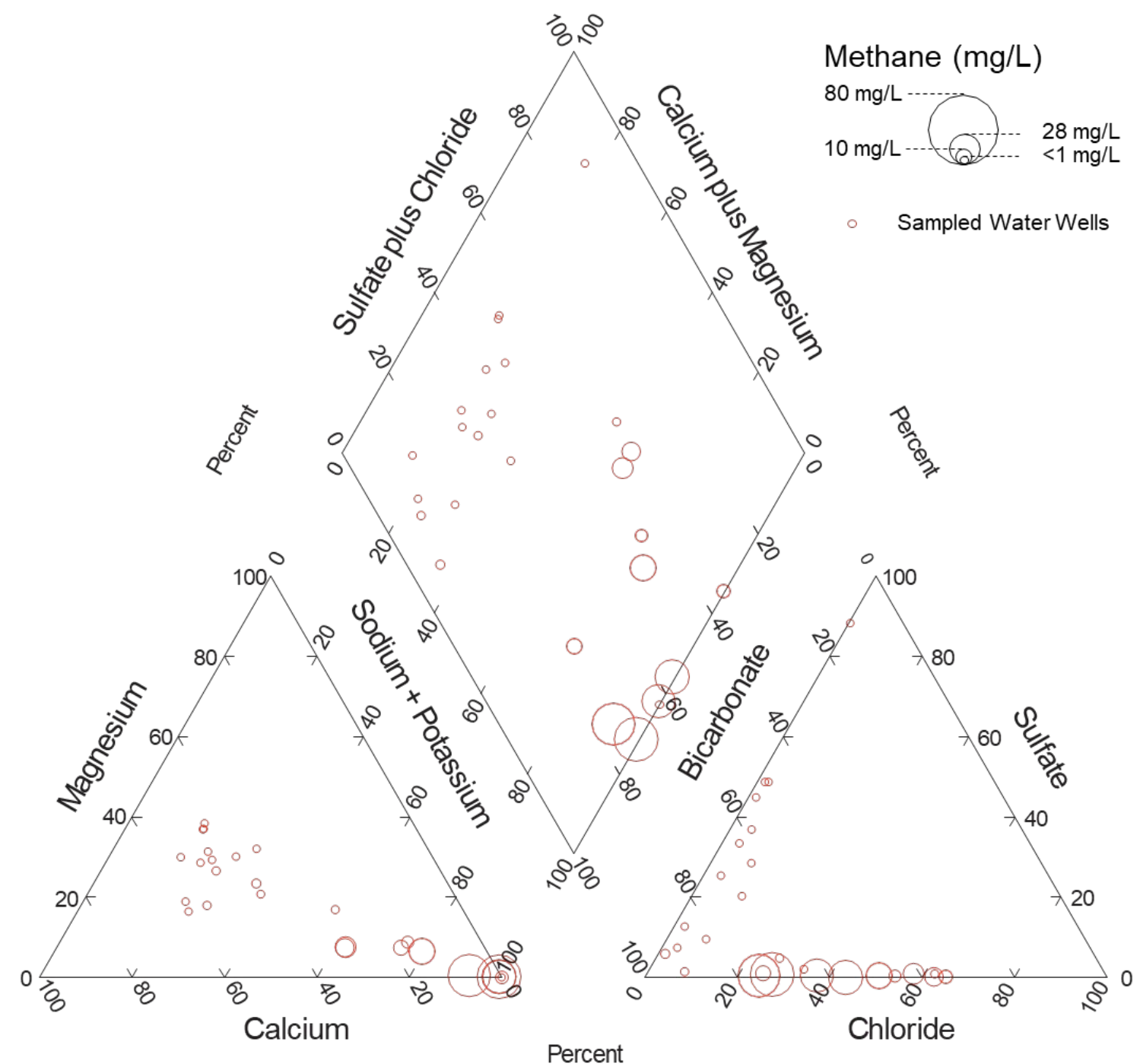

Figure 3. Modified Piper diagram of sampled water wells. Circle size is proportional to methane concentration.

\subsubsection{Dissolved Methane and Ethane Concentrations}

Dissolved methane shows a wide range of concentrations in water wells (Table 5).

Twelve $(50 \%)$ water wells have dissolved methane $>1 \mathrm{mg} / \mathrm{L}$, including six wells $>10$ $\mathrm{mg} / \mathrm{L}$, where the highest methane concentration measured was $50 \mathrm{mg} / \mathrm{L}$. Five wells have methane concentrations between 0.1 and $1 \mathrm{mg} / \mathrm{L}$, and seven wells have concentrations < $0.1 \mathrm{mg} / \mathrm{L}$. The water type of most samples with methane $>1 \mathrm{mg} / \mathrm{L}$ is $\mathrm{Na}-\mathrm{HCO}_{3}(\mathrm{n}=4)$, followed by $\mathrm{Na}-\mathrm{HCO}_{3}-\mathrm{Cl}(\mathrm{n}=3), \mathrm{Ca}-\mathrm{Na}-\mathrm{HCO}_{3}(\mathrm{n}=2), \mathrm{Ca}-\mathrm{HCO}_{3}(\mathrm{n}=2)$, and $\mathrm{Ca}-\mathrm{Na}-\mathrm{HCO}_{3}-$ 
$\mathrm{Cl}(\mathrm{n}=1)$ (Figures 3 and 4). Spearman's $\rho$ correlation analysis test was performed between water chemistry variables and methane concentrations (Table 6).

Table 5. Dissolved gas concentrations and stable isotope composition of water wells

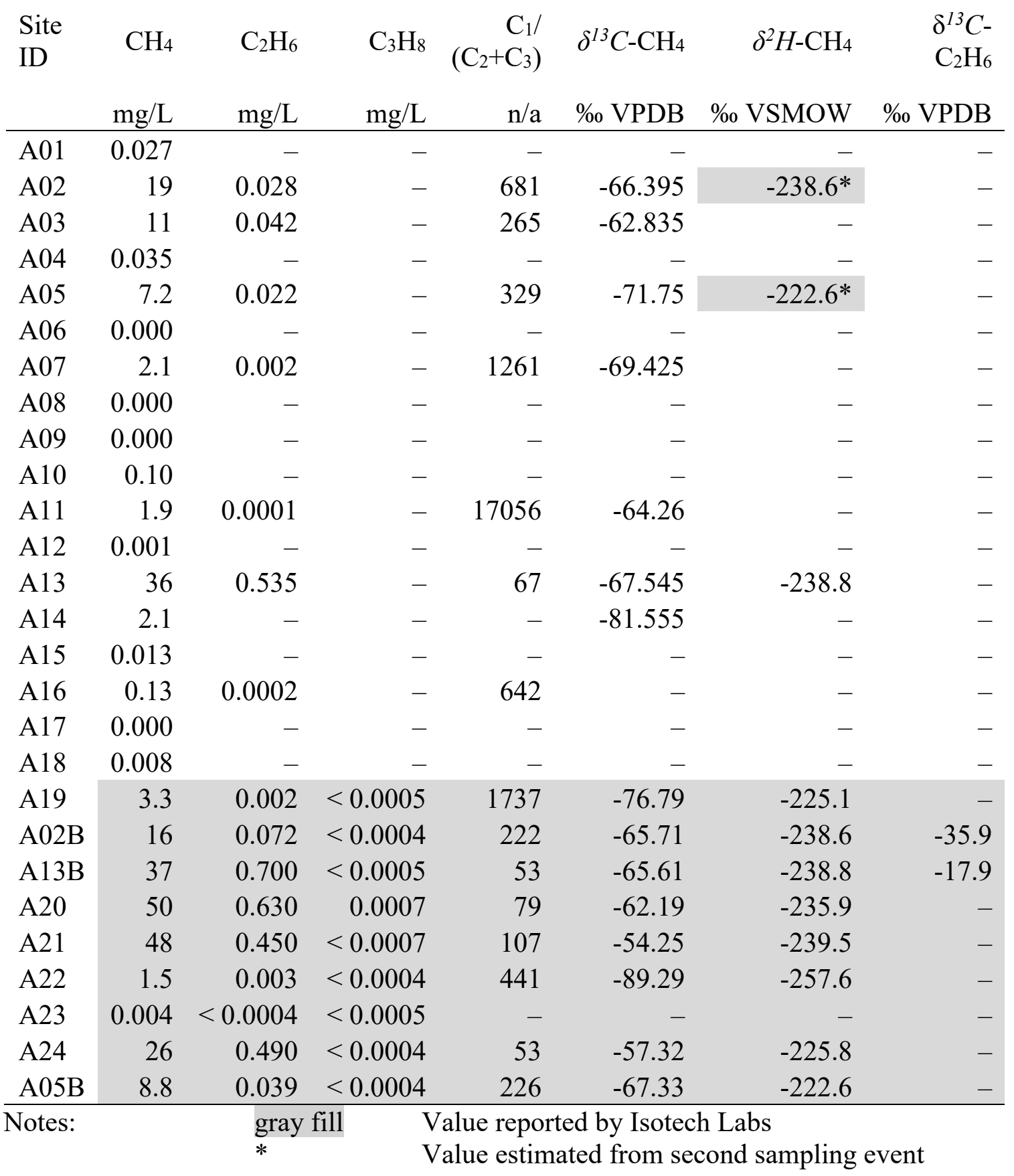


Table 5. Dissolved gas concentrations and stable isotope composition (cont.)

\begin{tabular}{|c|c|c|c|c|c|c|c|c|}
\hline \multirow[t]{2}{*}{$\begin{array}{l}\text { Site } \\
\text { ID }\end{array}$} & DIC & $\begin{array}{r}\delta^{13} C- \\
\text { DIC }\end{array}$ & $\begin{array}{r}\delta^{13} C- \\
\mathrm{CO}_{2}\end{array}$ & $\begin{array}{l}\delta^{13} C- \\
\text { DOC }\end{array}$ & $\delta^{34} S-\mathrm{SO}_{4}$ & $\delta^{18} \mathrm{O}-\mathrm{SO}_{4}$ & $\delta^{2} H$ & $\delta^{18} \mathrm{O}$ \\
\hline & $\mathrm{mg} / \mathrm{L}$ & \multicolumn{2}{|c|}{$\%$ VPDB } & $\%$ VPDB & \% VCDT & \% VSMOW & \multicolumn{2}{|c|}{ \% VSMOW } \\
\hline A01 & - & -16.4 & -25.4 & - & 15.7 & 12.6 & -43.8 & -7.0 \\
\hline A02 & - & -6.9 & -15.9 & - & - & - & -44.2 & -7.1 \\
\hline A03 & - & -13.9 & -23.0 & - & - & - & -42.3 & -7.0 \\
\hline A04 & - & -16.4 & -25.6 & - & 11.9 & 12.3 & -41.0 & -6.8 \\
\hline A05 & - & -14.7 & -23.6 & - & - & - & -42.4 & -6.7 \\
\hline A06 & - & -12.3 & -21.5 & - & -16.7 & 3.2 & -43.6 & -7.1 \\
\hline A07 & - & -21.5 & -30.7 & - & - & - & -42.9 & -6.8 \\
\hline A08 & - & -19.0 & -28.1 & - & 2.3 & 7.3 & -53.4 & -7.8 \\
\hline A09 & - & -19.9 & -29.2 & - & -1.1 & 4.0 & -45.9 & -7.5 \\
\hline A10 & - & -20.8 & -29.8 & - & 2.0 & -0.1 & -38.3 & -6.4 \\
\hline A11 & - & -12.6 & -21.5 & - & 54.7 & 16.7 & -44.5 & -7.2 \\
\hline A12 & - & -20.7 & -30.0 & - & 2.4 & 3.3 & -45.0 & -7.2 \\
\hline A13 & - & -0.5 & -9.6 & - & - & - & -43.1 & -6.9 \\
\hline A14 & - & -19.3 & -28.5 & - & 13.1 & 14.1 & -42.3 & -6.9 \\
\hline A15 & - & -19.9 & -28.9 & - & -3.0 & 6.0 & -43.1 & -7.0 \\
\hline A16 & - & -18.6 & -27.6 & - & 19.6 & 14.3 & -43.6 & -7.1 \\
\hline A17 & - & -10.1 & -19.2 & - & 2.6 & 3.2 & -48.6 & -7.8 \\
\hline A18 & - & - & - & - & 4.3 & 9.6 & -41.1 & -6.7 \\
\hline A19 & 49 & -11.6 & -20.7 & - & 0.7 & - & -43.7 & -7.0 \\
\hline A02B & 32 & -8.6 & -17.7 & -36.1 & - & - & -42.1 & -6.6 \\
\hline A13B & 78 & -0.8 & -9.9 & -30.6 & - & - & -43.0 & -7.0 \\
\hline A20 & 80 & 6.1 & -2.9 & -27.3 & - & - & -43.4 & -7.1 \\
\hline A21 & 62 & 4.3 & -4.9 & -27.5 & - & - & -41.8 & -6.8 \\
\hline A22 & 28 & -18.6 & -27.7 & -26.0 & - & - & -45.3 & -7.3 \\
\hline A23 & 18 & -9.1 & -18.2 & - & 0.9 & - & -44.3 & -7.1 \\
\hline A24 & 74.5 & 0.2 & -8.9 & - & - & - & -42.2 & -6.9 \\
\hline A05B & 70 & -14.7 & -23.7 & -25.2 & - & - & -42.8 & -6.9 \\
\hline
\end{tabular}


Table 6. Correlations between water chemistry parameters and methane concentrations. Asterisk (*) highlights correlations that are not statistically significant $(\mathrm{p}>0.05)$.

\begin{tabular}{lrr}
\hline Parameter & Spearman's $\rho$ & p-value of Spearman \\
\hline $\mathrm{Ca}$ & -0.16 & $4.18 \mathrm{E}-01^{*}$ \\
$\mathrm{Na}$ & 0.82 & $1.59 \mathrm{E}-07$ \\
$\mathrm{Mg}$ & 0.29 & $1.36 \mathrm{E}-01^{*}$ \\
$\mathrm{Cl}$ & 0.78 & $1.62 \mathrm{E}-06$ \\
$\mathrm{~K}$ & -0.04 & $8.47 \mathrm{E}-01^{*}$ \\
$\mathrm{HCO}_{3}$ & 0.70 & $4.11 \mathrm{E}-05$ \\
$\mathrm{SO}_{4}$ & -0.66 & $8.06 \mathrm{E}-04$ \\
$\mathrm{pH}$ & 0.86 & $9.52 \mathrm{E}-09$ \\
$\mathrm{Eh}$ & -0.77 & $2.39 \mathrm{E}-06$ \\
$\mathrm{SC}$ & 0.72 & $2.00 \mathrm{E}-05$ \\
$\mathrm{DO}$ & -0.68 & $9.67 \mathrm{E}-05$ \\
\hline
\end{tabular}

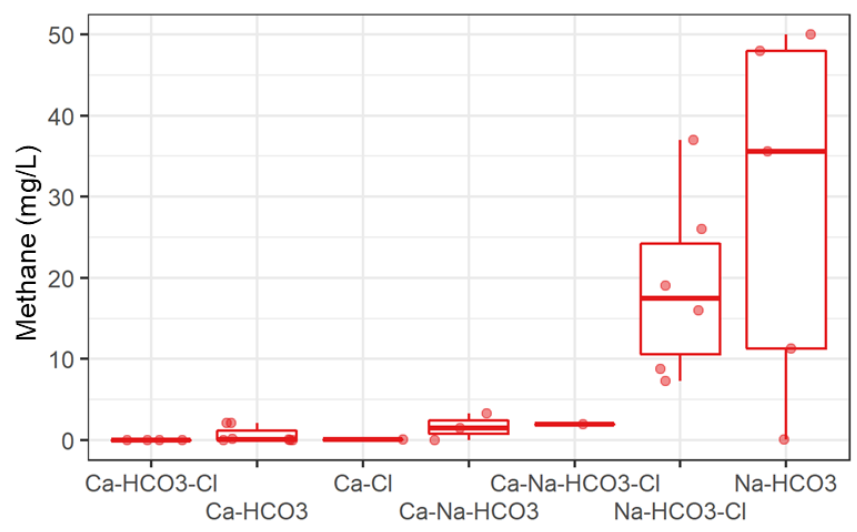

Figure 4. Concentration of methane compared to water type in box-and-whisker diagram.

Ethane was detected in 15 samples and in concentrations up to $0.70 \mathrm{mg} / \mathrm{L}$, whereas propane was only measurable in one sample (A20) at $0.0007 \mathrm{mg} / \mathrm{L}$. The molecular ratio of gases $\left(\mathrm{C}_{1} /\left(\mathrm{C}_{2}+\mathrm{C}_{3}\right)\right)$ ranged from $\sim 53$ to 17000 .

\subsection{Isotopic Composition}

\subsubsection{Methane Isotopes}

Measurements of $\delta^{13} \mathrm{C}-\mathrm{CH}_{4}$ were performed on 15 samples and ranged from $89.3 \%$ to $-54.3 \%$ (median $-66.4 \%$ ) (Table 5 ). $\delta^{2} H-\mathrm{CH}_{4}$ was measured on eight samples 
and ranged from $-257.6 \%$ to $-222.6 \%$ (median $238.6 \%$ ). $\delta^{13} C-\mathrm{C}_{2} \mathrm{H}_{6}$ was only measurable in 2 samples (A02 and A13) and had values of $-35.9 \%$ and $-17.9 \%$.

\subsubsection{Sulfate Isotopes}

Measurements of $\delta^{34} S-\mathrm{SO}_{4}$, which were possible on samples with $\mathrm{SO}_{4}$ concentrations $>5 \mathrm{mg} / \mathrm{L}(\mathrm{n}=15)$, ranged from $-16.7 \%$ to $54.7 \%$ (median $2.4 \%$ ) $($ Table 5$)$. The $\delta^{18} \mathrm{O}-\mathrm{SO}_{4}$ values on 13 samples ranged from $-0.1 \%$ o to $16.7 \%$ o (median $7.3 \%$ ).

\subsection{3 $\delta^{13} \mathrm{C}$ DIC \& DOC isotopes}

DIC concentrations, measured for nine wells, ranged from 18 to $80 \mathrm{mg} / \mathrm{L}$ (median $62.0 \mathrm{mg} / \mathrm{L})$. DIC concentrations were strongly $(\rho=0.98)$ and significantly $(p=1.94 \mathrm{E}-6)$ correlated with lab alkalinity, and similarly, though slightly less, correlated $(\rho=0.92, p=$ 5.07E-4) with field alkalinity (Figure 5). Measurements of $\delta^{13} C$-DIC were possible in all except one sample and ranged from $-21.5 \%$ to $6.1 \%$ (median -14.3\%o) (Table 5) (Figure 6). Values of $\delta^{13} C$-DIC were used to estimate $\delta^{13} C-\mathrm{CO}_{2}$ values using the equation (Clark and Fritz, 1997; Mook et al., 1974):

$$
\varepsilon_{\mathrm{HCO} 3-\mathrm{CO} 2}=1000 \ln \alpha{ }_{\mathrm{HCO} 3-\mathrm{CO} 2}=[9.552 *(1000 / \mathrm{T})]-24.1
$$

Measurements for $\delta^{13} \mathrm{C}$-DOC were possible in six samples and values ranged from $-36.1 \%$ to $-25.2 \%$ (median $-27.4 \%$ ). 


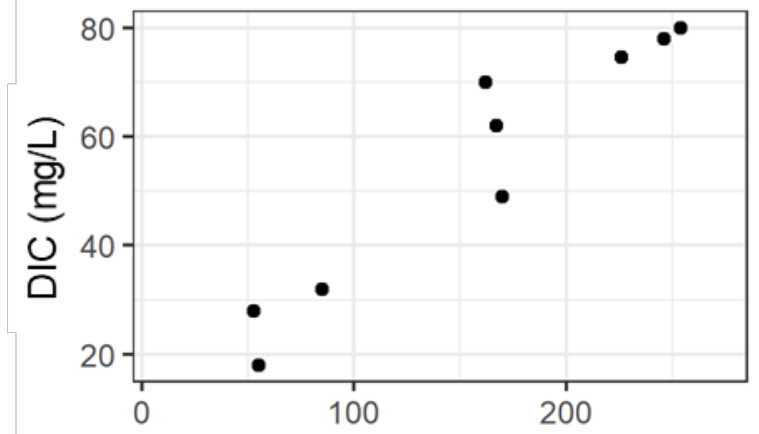

Field Alkalinity (mg/L as $\mathrm{CaCO} 3$ )

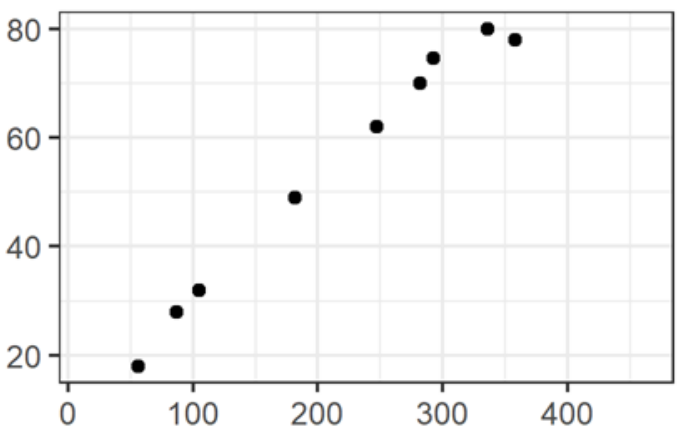

Lab Alkalinity (mg/L as CaCO3)

Figure 5. DIC concentrations in nine water samples compared to alkalinity measured in the field and in the lab.

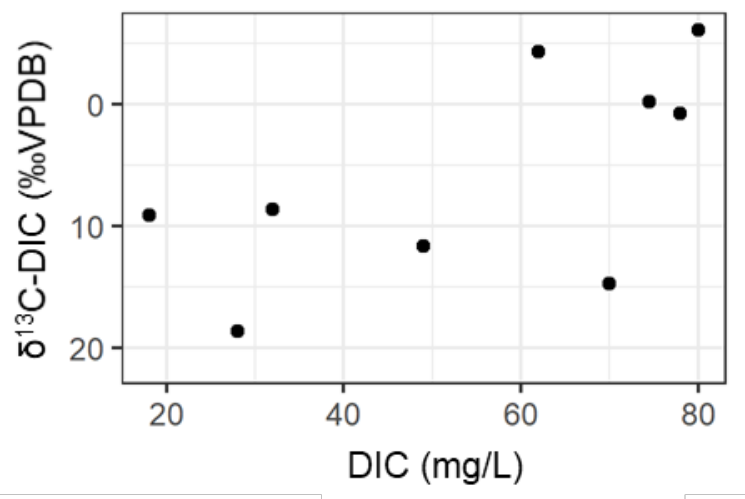

Figure 6. DIC concentrations compared to $\delta^{13} C$-DIC values.

\subsubsection{Water Isotopes}

The $\delta^{2} H$ values of groundwater ranged from $-53.4 \%$ to $-38.3 \%$ (median $-43.1 \%$ ), and the $\delta^{18} \mathrm{O}$ values from $-7.8 \%$ to $-6.4 \%$ (median $-7.0 \%$ ) (Figure 7). A linear regression of these values produced a slope of 7.8 and intercept of 11.3 , whereas a linear regression of the data in Letcher County (LeDoux et al., 2016) produced a slope of 6.7 and an intercept of 3.6. The values of $\delta^{2} H$ are more positive, and the values of $\delta^{18} O$ are more negative than the Global Meteoric Water Line (GMWL) defined in Craig (1961), with a slope of 8 and intercept of 10. The values of $\delta^{2} H$ and $\delta^{18} O$ fall near the Kentucky Meteoric Water Line (KMWL) calculated in Kendall and Coplen (2001), with a slope of 6.4 and intercept of 1.2. 
Two samples, however, fall noticeably outside this line. One well (A08) with a significantly more negative $\delta^{2} H$ value was reported by the lab as being below the dynamic range of the instrument. Another well (A10) has a more positive $\delta^{2} H$ value or more negative $\delta^{18} \mathrm{O}$ value in relation to the KMWL. This water well was meters away from an orange creek, which was possibly contaminated by acid mine drainage.

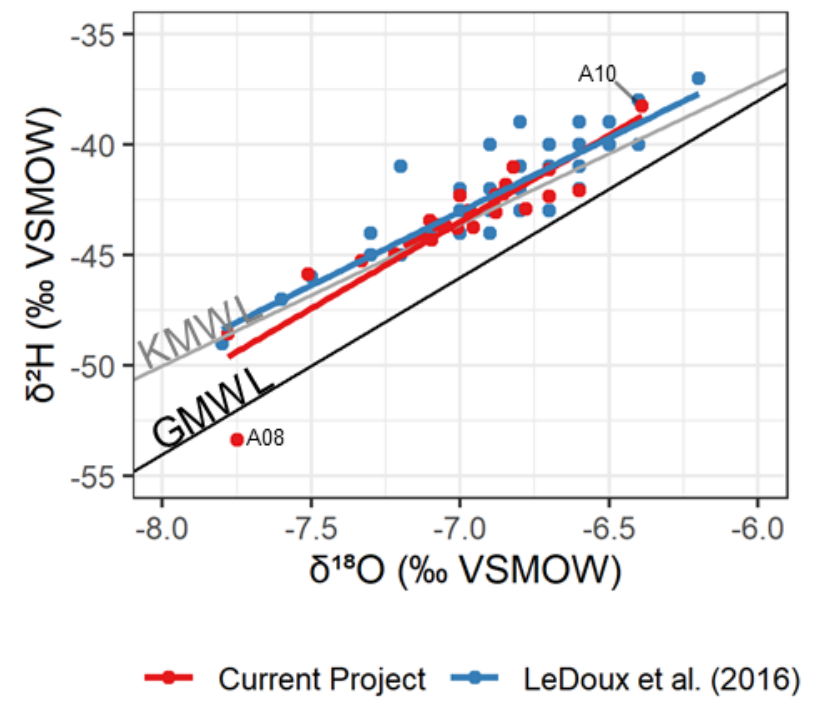

Figure 7. Bivariate plot of $\delta^{2} H$ vs. $\delta^{18} O$ data for this study and LeDoux et al. (2016). Blue and red lines are linear regressions of each study. Black line illustrates GMWL, gray line illustrates KMWL.

\section{DISCUSSION}

\subsection{Water Chemistry}

\subsubsection{Geochemical Analysis}

Saturation indexes (SI) were calculated in PHREEQC (Table 7) (Parkhurst and Appelo, 2013) using temperature, $\mathrm{pH}$, and concentrations of sulfide (Table 1), cations (Table 2 and 3) (except As and Ni), and anions (Table 4). Goethite, hematite, pyrite, sphalerite, and sulfur are supersaturated mineral phases in most water wells. Barite, siderite, rhodochrosite, $\mathrm{FeS}, \mathrm{SiO}_{2}$, and $\mathrm{Fe}(\mathrm{OH})_{3}$ minerals are at or near equilibrium in most 
wells. Anhydrite, gypsum, calcite, dolomite, fluorite, halite, sylvite and talc are undersaturated in most wells. Seven wells (A03, A04, A13, A23, and the three hand-dug wells) are undersaturated in most minerals. 
Table 7. Mineral saturation indexes (SI) in water samples

\begin{tabular}{|c|c|c|c|c|c|c|c|}
\hline Mineral & Formula & A01 & A02 & A03 & A04 & A05 & A06 \\
\hline Anhydrite & $\mathrm{CaSO}_{4}$ & -2.25 & - & - & -5.52 & - & -2.19 \\
\hline Aragonite & $\mathrm{CaCO}_{3}$ & -1.1 & -1.62 & -0.46 & -4.36 & -0.37 & -1.5 \\
\hline Barite & $\mathrm{BaSO}_{4}$ & 0.88 & - & - & - & - & 0.07 \\
\hline Calcite & $\mathrm{CaCO}_{3}$ & -0.95 & -1.46 & -0.31 & -4.21 & -0.22 & -1.35 \\
\hline Celestite & $\mathrm{SrSO}_{4}$ & -2.01 & - & - & - & - & -2.36 \\
\hline Chalcedony & $\mathrm{SiO}_{2}$ & 0.03 & -0.09 & -0.2 & -0.12 & -0.28 & -0.22 \\
\hline Chrysotile & $\mathrm{Mg}_{3} \mathrm{Si}_{2} \mathrm{O}_{5}(\mathrm{OH})_{4}$ & -11.3 & -13.4 & -6.63 & - & -7.6 & -13.3 \\
\hline Dolomite & $\mathrm{CaMg}\left(\mathrm{CO}_{3}\right)_{2}$ & -2.12 & -3.53 & -1.02 & - & -0.69 & -3.29 \\
\hline $\mathrm{Fe}(\mathrm{OH}) 3(\mathrm{a})$ & $\mathrm{Fe}(\mathrm{OH})_{3}$ & 0.39 & 1.43 & - & - & 3.05 & 0.14 \\
\hline FeS(ppt) & $\mathrm{FeS}$ & -0.47 & -1.27 & - & - & 0.83 & -1.34 \\
\hline Fluorite & $\mathrm{CaF}_{2}$ & -2.27 & -2.84 & -2.38 & - & -3.2 & -3 \\
\hline Goethite & $\mathrm{FeOOH}$ & 5.91 & 6.97 & - & - & 8.6 & 5.62 \\
\hline Gypsum & $\mathrm{CaSO}_{4}: 2 \mathrm{H}_{2} \mathrm{O}$ & -1.83 & - & - & -5.09 & - & -1.76 \\
\hline Halite & $\mathrm{NaCl}$ & -8.22 & -6.69 & -7.04 & -7.57 & -5.95 & -8.88 \\
\hline Hausmannite & $\mathrm{Mn}_{3} \mathrm{O}_{4}$ & -19.2 & -20.2 & -14.15 & - & -14.4 & -23.4 \\
\hline Hematite & $\mathrm{Fe}_{2} \mathrm{O}_{3}$ & 13.78 & 15.9 & - & - & 19.17 & 13.2 \\
\hline Jarosite-K & $\mathrm{KFe}_{3}\left(\mathrm{SO}_{4}\right)_{2}(\mathrm{OH})_{6}$ & -6.3 & - & - & - & - & -6.98 \\
\hline Mackinawite & $\mathrm{FeS}$ & 0.27 & -0.54 & - & - & 1.56 & -0.61 \\
\hline Manganite & $\mathrm{MnOOH}$ & -7.04 & -7.41 & -4.91 & - & -5.22 & -8.34 \\
\hline Melanterite & $\mathrm{FeSO}_{4}: 7 \mathrm{H}_{2} \mathrm{O}$ & -6.1 & - & - & - & - & -6.09 \\
\hline Pyrite & $\mathrm{FeS}_{2}$ & 23.08 & 20.39 & - & - & 25.46 & 21.42 \\
\hline Pyrochroite & $\mathrm{Mn}(\mathrm{OH})_{2}$ & -7.44 & -7.8 & -6.5 & - & -6.44 & -8.69 \\
\hline Pyrolusite & $\mathrm{MnO}_{2}: \mathrm{H}_{2} \mathrm{O}$ & -14.2 & -14.5 & -10.95 & - & -11.4 & -15.8 \\
\hline Quartz & $\mathrm{SiO}_{2}$ & 0.49 & 0.37 & 0.26 & 0.34 & 0.18 & 0.24 \\
\hline Rhodochrosite & $\mathrm{MnCO}_{3}$ & -0.56 & -1.18 & -0.89 & - & -0.27 & -2.11 \\
\hline Sepiolite & $\mathrm{Mg}_{2} \mathrm{Si}_{3} \mathrm{O}_{7} .5 \mathrm{OH}: 3 \mathrm{H}_{2} \mathrm{O}$ & -7.32 & -8.93 & -4.57 & - & -5.39 & -9.04 \\
\hline Sepiolite(d) & $\mathrm{Mg}_{2} \mathrm{Si}_{3} \mathrm{O}_{7} .5 \mathrm{OH}: 3 \mathrm{H}_{2} \mathrm{O}$ & -9.95 & -11.6 & -7.19 & - & -8.03 & -11.6 \\
\hline Siderite & $\mathrm{FeCO}_{3}$ & -0.58 & 0.2 & - & - & 0.53 & -1.05 \\
\hline $\mathrm{SiO} 2(\mathrm{a})$ & $\mathrm{SiO}_{2}$ & -0.84 & -0.97 & -1.08 & -1 & -1.15 & -1.1 \\
\hline Smithsonite & $\mathrm{ZnCO}_{3}$ & -6.2 & -2.49 & - & -6.78 & -5.85 & -5.11 \\
\hline Sphalerite & $\mathrm{ZnS}$ & 2.76 & 4.88 & - & 2.33 & 3.28 & 3.49 \\
\hline Strontianite & $\mathrm{SrCO}_{3}$ & -2.31 & -3.02 & -1.06 & - & -1.36 & -3.11 \\
\hline Sulfur & $\mathrm{S}$ & 10.65 & 8.79 & 12.29 & 10.72 & 11.77 & 9.83 \\
\hline Sylvite & $\mathrm{KCl}$ & -8.76 & -7.61 & -8.03 & -9.49 & -7.27 & -9.45 \\
\hline Talc & $\mathrm{Mg}_{3} \mathrm{Si}_{4} \mathrm{O}_{10}(\mathrm{OH})_{2}$ & -7.7 & -10 & -3.48 & - & -4.58 & -10.2 \\
\hline Willemite & $\mathrm{Zn}_{2} \mathrm{SiO}_{4}$ & -13.2 & -5.3 & - & -13.65 & -11.3 & -10.7 \\
\hline Witherite & $\mathrm{BaCO}_{3}$ & -3.43 & -4.1 & -2.07 & - & -2.26 & -4.7 \\
\hline $\mathrm{Zn}(\mathrm{OH}) 2(\mathrm{e})$ & $\mathrm{Zn}(\mathrm{OH})_{2}$ & -8.18 & -4.2 & - & -8.27 & -7.11 & -6.77 \\
\hline
\end{tabular}

Notes: $\quad$ Fill Color of cells is set to yellow at a SI of 0 , positive values are shades of green, and negative values are shades of red. 
Table 7. Mineral saturation indexes (SI) in water samples (cont.)

\begin{tabular}{|c|c|c|c|c|c|c|c|}
\hline Mineral & Formula & A07 & A08 & A09 & $\mathrm{A} 10$ & A11 & $\mathrm{A} 12$ \\
\hline Anhydrite & $\mathrm{CaSO}_{4}$ & - & -4.12 & -3.67 & -1.31 & -3.34 & -3.69 \\
\hline Arag & $\mathrm{CaCO}_{3}$ & -1.64 & -4.57 & -3.79 & -1.53 & -0.7 & -3.92 \\
\hline Barite & $\mathrm{BaSO}_{4}$ & - & -1.27 & -0.87 & 0.35 & 0.3 & -0.62 \\
\hline Calcite & $\mathrm{CaCO}_{3}$ & -1.48 & -4.42 & -3.63 & -1.38 & -0.55 & -3.76 \\
\hline Celestite & $\mathrm{SrSO}_{4}$ & - & -4.11 & -3.74 & -1.34 & -2.86 & -3.79 \\
\hline Chalc & $\mathrm{SiO}_{2}$ & 0.02 & -0.52 & -0.38 & -0.19 & -0.26 & -0.34 \\
\hline Chrys & $\mathrm{Mg}_{3} \mathrm{Si}_{2} \mathrm{O}_{5}(\mathrm{OH})_{4}$ & -10.3 & -22.44 & -18.68 & -11.5 & -9.65 & -21.07 \\
\hline Dolo & $\mathrm{CaN}$ & -3.25 & & -7.42 & -2.84 & -1.3 & -7.73 \\
\hline $\mathrm{Fe}(\mathrm{O}$ & & 1.65 & & & 1.73 & 2.4 & -3.05 \\
\hline $\mathrm{FeS}$ & & 0.03 & & & 0.35 & & -2.91 \\
\hline Fluo & & -2.2 & - & - & - & - & - \\
\hline Goe & & 7.14 & & & 7.28 & 7.96 & 2.38 \\
\hline Gyl & & - & & & -0.9 & & -3.25 \\
\hline Hal & & -8.31 & & & 79 & -6 & 10.19 \\
\hline & & -18.2 & -33.93 & -30.86 & .2 & -16.6 & 33.54 \\
\hline & & 16.23 & & 8.5 & 16.52 & 17.89 & 6.72 \\
\hline & & - & -19.09 & -13.65 & -0.05 & -3.19 & -14.57 \\
\hline & $\mathrm{F}$ & 0.77 & & -1.53 & 1.09 & -0.34 & -2.17 \\
\hline & & -6.52 & -12 & -10.91 & -6.77 & -6.15 & -11.95 \\
\hline & & - & & -7.12 & -3.68 & -6.26 & -6.87 \\
\hline Pyr & & 23.72 & & 20.05 & 23.07 & 20.84 & 18.46 \\
\hline & & -7.22 & -11 & -10.65 & -7.07 & -6.88 & -11.29 \\
\hline Pyr & & -13.5 & -20 & -19.16 & -13.9 & -12.8 & -20.58 \\
\hline Qua & 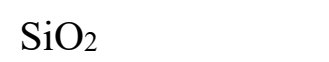 & 0.49 & 006 & 0.08 & 0.27 & 0.19 & 0.13 \\
\hline Rho & $\mathrm{MnCO}_{3}$ & -1.32 & -4.74 & -4.29 & -0.55 & -0.29 & -4.28 \\
\hline & $\mathrm{Mg}_{2} \mathrm{Si}_{3} \mathrm{O}$ & -6.59 & -15.66 & -12.83 & -7.81 & -6.75 & -14.35 \\
\hline Sepio & $\mathrm{Mg}_{2} \mathrm{Si}_{3} \mathrm{O}$ & -9.2 & -18.28 & -15.38 & -10.5 & -9.41 & -16.91 \\
\hline & $\mathrm{FeCO}_{3}$ & -0.58 & -4.26 & -2.92 & 0.5 & 0.79 & -2.77 \\
\hline & & -0.85 & -1.4 & -1.27 & -1.06 & -1.13 & -1.22 \\
\hline & $\mathrm{ZnCO}$ & -7.23 & -6.01 & -7.17 & -4.5 & -1 & -5.9 \\
\hline & $\mathrm{Zn}$ & 2.26 & 3.02 & 2.4 & 4.19 & 5.16 & 2.87 \\
\hline Strol & $\mathrm{SrCO}_{3}$ & -2.87 & -6 & -5.29 & -3 & -1.66 & -5.45 \\
\hline Sul & $\mathrm{S}$ & 10.77 & 8.1 & 9.33 & 9.85 & 9.07 & 8.38 \\
\hline Sylvit & $\mathrm{KC}$ & -8.68 & - & - & -9.2 & -6.97 & -9.33 \\
\hline $\mathrm{Tal}$ & & -6.66 & & & -8.26 & -6.61 & -18.22 \\
\hline & & -13.4 & & & -9.24 & -4.02 & 3.42 \\
\hline & & -3.72 & & -6.47 & -5.32 & -2.51 & -6.32 \\
\hline $\mathrm{Zn}(\mathrm{OH}) 2(\mathrm{e})$ & $\mathrm{Zn}(\mathrm{OH})_{2}$ & -8.23 & -7.88 & -8.61 & -6.13 & -3.51 & -7.99 \\
\hline
\end{tabular}


Table 7. Mineral saturation indexes (SI) in water samples (cont.)

\begin{tabular}{|c|c|c|c|c|c|c|}
\hline Mineral & Formula & A13 & A14 & A15 & A16 & A17 \\
\hline Anhydrite & $\mathrm{CaSO}_{4}$ & - & -3.09 & -3.02 & -3.31 & -3.31 \\
\hline Aragonite & $\mathrm{CaCO}_{3}$ & -0.39 & -1.32 & -2.46 & -1.71 & -2.1 \\
\hline Barite & $\mathrm{BaSO}_{4}$ & - & 0.41 & -0.29 & 0.26 & -0.15 \\
\hline Calcite & $\mathrm{CaCO}_{3}$ & -0.24 & -1.17 & -2.31 & -1.56 & -1.95 \\
\hline Celestite & $\mathrm{SrSO}_{4}$ & - & -2.78 & -3.23 & -2.89 & -3.07 \\
\hline Chalcedony & $\mathrm{SiO}_{2}$ & -0.48 & -0.05 & -0.14 & -0.04 & -0.47 \\
\hline Chrysotile & $\mathrm{Mg}_{3} \mathrm{Si}_{2} \mathrm{O}_{5}(\mathrm{OH})_{4}$ & -3.73 & -12.8 & -16.5 & -13.6 & -14.9 \\
\hline Dolomite & $\mathrm{CaMg}\left(\mathrm{CO}_{3}\right)_{2}$ & -0.91 & -2.85 & -4.87 & -3.62 & -4.18 \\
\hline $\mathrm{Fe}(\mathrm{OH}) 3(\mathrm{a})$ & $\mathrm{Fe}(\mathrm{OH})_{3}$ & - & 1.39 & -0.33 & 1.11 & -1.26 \\
\hline $\mathrm{FeS}(\mathrm{ppt})$ & $\mathrm{FeS}$ & - & 0.47 & -0.44 & -0.1 & -2.24 \\
\hline Fluorite & $\mathrm{CaF}_{2}$ & -2.38 & -2.77 & -3.14 & -2.95 & - \\
\hline Goethite & $\mathrm{FeOOH}$ & - & 6.88 & 5.22 & 6.65 & 4.24 \\
\hline Gypsum & $\mathrm{CaSO}_{4}: 2 \mathrm{H}_{2} \mathrm{O}$ & - & -2.66 & -2.61 & -2.9 & -2.88 \\
\hline Halite & $\mathrm{NaCl}$ & -6.15 & -7.52 & -8.66 & -9.06 & -9.63 \\
\hline Hausmannite & $\mathrm{Mn}_{3} \mathrm{O}_{4}$ & -9.52 & -20.2 & -22.9 & -21.9 & -25.1 \\
\hline Hematite & $\mathrm{Fe}_{2} \mathrm{O}_{3}$ & - & 15.72 & 12.4 & 15.26 & 10.44 \\
\hline Jarosite-K & $\mathrm{KFe}_{3}\left(\mathrm{SO}_{4}\right)_{2}(\mathrm{OH})_{6}$ & - & -4.87 & -7.6 & -5.6 & -12.1 \\
\hline Mackinawite & $\mathrm{FeS}$ & - & 1.2 & 0.3 & 0.63 & -1.5 \\
\hline Manganite & $\mathrm{MnOOH}$ & -2.93 & -7.32 & -8.53 & -8.01 & -9.02 \\
\hline Melanterite & $\mathrm{FeSO}_{4}: 7 \mathrm{H}_{2} \mathrm{O}$ & - & -5.71 & -5.41 & -5.91 & -7.75 \\
\hline Pyrite & $\mathrm{FeS}_{2}$ & - & 23.79 & 22.05 & 22.75 & 20.47 \\
\hline Pyrochroite & $\mathrm{Mn}(\mathrm{OH})_{2}$ & -5.8 & -7.67 & -8.33 & -8.3 & -9.18 \\
\hline Pyrolusite & $\mathrm{MnO}_{2}: \mathrm{H}_{2} \mathrm{O}$ & -7.72 & -14.7 & -16.2 & -15.2 & -16.5 \\
\hline Quartz & $\mathrm{SiO}_{2}$ & -0.02 & 0.42 & 0.32 & 0.43 & -0.01 \\
\hline Rhodochrosite & $\mathrm{MnCO}_{3}$ & -1.31 & -0.86 & -1.19 & -1.58 & -2.5 \\
\hline Sepiolite & 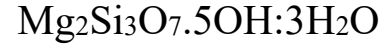 & -3.09 & -8.44 & -11.1 & -8.94 & -10.6 \\
\hline Sepiolite(d) & 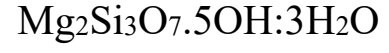 & -5.7 & -11 & -13.8 & -11.6 & -13.2 \\
\hline Siderite & $\mathrm{FeCO}_{3}$ & - & 0.42 & -0.45 & 0.09 & -2.17 \\
\hline $\mathrm{SiO} 2(\mathrm{a})$ & $\mathrm{SiO}_{2}$ & -1.36 & -0.92 & -1.01 & -0.91 & -1.35 \\
\hline Smithsonite & $\mathrm{ZnCO}_{3}$ & - & -6.83 & -6.26 & -6.44 & -5.49 \\
\hline Sphalerite & $\mathrm{ZnS}$ & - & 2.09 & 2.58 & 2.21 & 3.31 \\
\hline Strontianite & $\mathrm{SrCO}_{3}$ & -0.65 & -2.46 & -4.11 & -2.72 & -3.3 \\
\hline Sulfur & $\mathrm{S}$ & 13.01 & 10.41 & 9.62 & 9.97 & 9.8 \\
\hline Sylvite & $\mathrm{KCl}$ & -7.78 & -8.09 & -8.91 & -9.33 & -9.57 \\
\hline Talc & $\mathrm{Mg}_{3} \mathrm{Si}_{4} \mathrm{O}_{10}(\mathrm{OH})_{2}$ & -1.14 & -9.39 & -13.2 & -10.1 & -12.3 \\
\hline Willemite & $\mathrm{Zn}_{2} \mathrm{SiO}_{4}$ & - & -14.4 & -13.9 & -13.4 & -11.9 \\
\hline Witherite & $\mathrm{BaCO}_{3}$ & -1.56 & -3.29 & -5.18 & -3.58 & -4.4 \\
\hline $\mathrm{Zn}(\mathrm{OH}) 2(\mathrm{e})$ & $\mathrm{Zn}(\mathrm{OH})_{2}$ & - & -8.72 & -8.5 & -8.26 & -7.26 \\
\hline
\end{tabular}


Table 7. Mineral saturation indexes (SI) in water samples (cont.)

\begin{tabular}{|c|c|c|c|c|c|c|}
\hline Mineral & Formula & A18 & A19 & A02B & A13B & A20 \\
\hline Anhydrite & $\mathrm{CaSO}_{4}$ & -2.97 & -3.22 & -4.54 & -6.13 & -5.39 \\
\hline Aragonite & $\mathrm{CaCO}_{3}$ & -1.55 & -1.3 & -1.77 & -0.5 & -0.63 \\
\hline Barite & $\mathrm{BaSO}_{4}$ & 0.1 & -0.24 & -1.54 & -1.89 & -1.28 \\
\hline Calcite & $\mathrm{CaCO}_{3}$ & -1.4 & -1.15 & -1.61 & -0.35 & -0.48 \\
\hline Celestite & $\mathrm{SrSO}_{4}$ & -3 & -3.25 & -4.51 & -4.97 & -4.36 \\
\hline Chalcedony & $\mathrm{SiO}_{2}$ & -0.15 & -0.13 & -0.07 & -0.53 & -0.52 \\
\hline Chrysotile & $\mathrm{Mg}_{3} \mathrm{Si}_{2} \mathrm{O}_{5}(\mathrm{OH})_{4}$ & -13.1 & -12 & -13.7 & -4.62 & -5.4 \\
\hline Dolomite & $\mathrm{CaMg}\left(\mathrm{CO}_{3}\right)_{2}$ & -2.88 & -2.56 & -3.85 & -1.17 & -1.46 \\
\hline $\mathrm{Fe}(\mathrm{OH}) 3(\mathrm{a})$ & $\mathrm{Fe}(\mathrm{OH})_{3}$ & 0.56 & 1.03 & 1.4 & - & 1.4 \\
\hline $\mathrm{FeS}(\mathrm{ppt})$ & $\mathrm{FeS}$ & -0.14 & 0.37 & 0.28 & - & -2.9 \\
\hline Fluorite & $\mathrm{CaF}_{2}$ & -2.78 & -2.21 & -2.57 & -2.04 & -2.38 \\
\hline Goethite & $\mathrm{FeOOH}$ & 6.06 & 6.55 & 6.92 & - & 6.93 \\
\hline Gypsum & $\mathrm{CaSO}_{4}: 2 \mathrm{H}_{2} \mathrm{O}$ & -2.54 & -2.8 & -4.12 & -5.7 & -4.98 \\
\hline Halite & $\mathrm{NaCl}$ & -7.98 & -8.82 & -6.73 & -6.09 & -6.46 \\
\hline Hausmannite & $\mathrm{Mn}_{3} \mathrm{O}_{4}$ & -20.9 & -20.8 & -20.8 & -10.27 & -10.2 \\
\hline Hematite & $\mathrm{Fe}_{2} \mathrm{O}_{3}$ & 14.07 & 15.05 & 15.8 & - & 15.81 \\
\hline Jarosite-K & $\mathrm{KFe}_{3}\left(\mathrm{SO}_{4}\right)_{2}(\mathrm{OH})_{6}$ & -6.27 & -6.16 & -7.24 & - & -12.8 \\
\hline Mackinawite & $\mathrm{FeS}$ & 0.59 & 1.11 & 1.01 & - & -2.17 \\
\hline Manganite & $\mathrm{MnOOH}$ & -7.6 & -7.52 & -7.59 & -3.2 & -3.29 \\
\hline Melanterite & $\mathrm{FeSO}_{4}: 7 \mathrm{H}_{2} \mathrm{O}$ & -5.87 & -6.43 & -7.02 & - & -13.1 \\
\hline Pyrite & $\mathrm{FeS}_{2}$ & 23.01 & 24.33 & 23.45 & - & 23.85 \\
\hline Pyrochroite & $\mathrm{Mn}(\mathrm{OH})_{2}$ & -7.82 & -7.99 & -7.95 & -5.93 & -5.91 \\
\hline Pyrolusite & $\mathrm{MnO}_{2}: \mathrm{H}_{2} \mathrm{O}$ & -15 & -14.6 & -14.8 & -8.18 & -8.21 \\
\hline Quartz & $\mathrm{SiO}_{2}$ & 0.31 & 0.33 & 0.39 & -0.07 & -0.06 \\
\hline Rhodochrosite & $\mathrm{MnCO}_{3}$ & -0.81 & -1.25 & -1.4 & -1.33 & -1.16 \\
\hline Sepiolite & $\mathrm{Mg}_{2} \mathrm{~S}$ & -8.76 & -8.02 & -9.07 & -3.76 & -4.3 \\
\hline Sepiolite(d) & $\mathrm{Mg}_{2} \mathrm{Si}_{3} \mathrm{O}_{7} .5 \mathrm{C}$ & -11.4 & -10.6 & -11.7 & -6.36 & -6.93 \\
\hline Siderite & $\mathrm{FeCO}_{3}$ & -0.09 & -0.14 & 0.14 & - & -3.93 \\
\hline $\mathrm{SiO} 2(\mathrm{a})$ & $\mathrm{SiO}_{2}$ & -1.03 & -1.01 & -0.94 & -1.41 & -1.39 \\
\hline Smithsonite & $\mathrm{ZnCO}_{3}$ & -5.81 & -7.32 & -4.84 & - & -5.58 \\
\hline Sphalerite & $\mathrm{ZnS}$ & 2.99 & 2.05 & 4.15 & - & 4.29 \\
\hline Strontianite & $\mathrm{SrCO}_{3}$ & -3.02 & -2.77 & -3.17 & -0.77 & -1.03 \\
\hline Sulfur & $\mathrm{S}$ & 10.24 & 11.06 & 10.28 & 13.95 & 13.87 \\
\hline Sylvite & $\mathrm{KCl}$ & -8.48 & -9.39 & -7.63 & -7.63 & -8.05 \\
\hline Talc & $\mathrm{Mg}_{3} \mathrm{Si}_{4} \mathrm{O}_{10}(\mathrm{OH})_{2}$ & -9.8 & -8.67 & -10.3 & -2.13 & -2.88 \\
\hline Willemite & $\mathrm{Zn}_{2} \mathrm{SiO}_{4}$ & -12.9 & -15.3 & -9.89 & - & -8.21 \\
\hline Witherite & $\mathrm{BaCO}_{3}$ & -3.94 & -3.78 & -4.22 & -1.73 & -1.97 \\
\hline $\mathrm{Zn}(\mathrm{OH}) 2(\mathrm{e})$ & $\mathrm{Zn}(\mathrm{OH})_{2}$ & -7.92 & -9.16 & -6.49 & - & -5.42 \\
\hline
\end{tabular}


Table 7. Mineral saturation indexes (SI) in water samples (cont.)

\begin{tabular}{|c|c|c|c|c|c|c|}
\hline Mineral & Formula & A21 & A22 & A23 & A24 & $\mathrm{A} 05 \mathrm{~B}$ \\
\hline Anhydrite & $\mathrm{CaSO}_{4}$ & -5.08 & -4.24 & -2.7 & -4.49 & -7.32 \\
\hline Aragonite & $\mathrm{CaCO}_{3}$ & -1.12 & -2.19 & -2.26 & -0.44 & -3.23 \\
\hline Barite & $\mathrm{BaSO}_{4}$ & -1.75 & -0.81 & 0.01 & -0.67 & - \\
\hline Calcite & $\mathrm{CaCO}_{3}$ & -0.96 & -2.04 & -2.11 & -0.29 & -3.08 \\
\hline Celestite & $\mathrm{SrSO}_{4}$ & -4.56 & -4.17 & -2.07 & -3.82 & - \\
\hline Chalcedony & $\mathrm{SiO}_{2}$ & -0.33 & -0.08 & -0.41 & -0.22 & -0.32 \\
\hline Chrysotile & $\mathrm{Mg}_{3} \mathrm{Si}_{2} \mathrm{O}_{5}(\mathrm{OH})_{4}$ & -12.2 & -13.6 & -14.32 & -7.68 & -16.4 \\
\hline Dolomite & $\mathrm{CaMg}\left(\mathrm{CO}_{3}\right)_{2}$ & -3.12 & -4.41 & -4.33 & -0.94 & -6.72 \\
\hline $\mathrm{Fe}(\mathrm{OH}) 3(\mathrm{a})$ & $\mathrm{Fe}(\mathrm{OH})_{3}$ & 2.09 & 1.69 & - & 2.46 & 1.98 \\
\hline $\mathrm{FeS}(\mathrm{ppt})$ & $\mathrm{FeS}$ & 0.24 & 1.08 & - & 0.51 & 0.16 \\
\hline Fluorite & $\mathrm{CaF}_{2}$ & -1.85 & -2.88 & -3.13 & -1.32 & -3.85 \\
\hline Goethite & $\mathrm{FeOOH}$ & 7.58 & 7.19 & - & 7.98 & 7.53 \\
\hline Gypsum & $\mathrm{CaSO}_{4}: 2 \mathrm{H}_{2} \mathrm{O}$ & -4.65 & -3.82 & -2.28 & -4.07 & -6.91 \\
\hline Halite & $\mathrm{NaCl}$ & -6.87 & -8.04 & -9.62 & -6.08 & -5.84 \\
\hline Hausmannite & $\mathrm{Mn}_{3} \mathrm{O}_{4}$ & -16.1 & -20.2 & -24.21 & -15.5 & - \\
\hline Hematite & $\mathrm{Fe}_{2} \mathrm{O}_{3}$ & 17.12 & 16.33 & - & 17.93 & 17.03 \\
\hline Jarosite-K & $\mathrm{KFe}_{3}\left(\mathrm{SO}_{4}\right)_{2}(\mathrm{OH})_{6}$ & -8.2 & -5.64 & - & -6.64 & -9.07 \\
\hline Mackinawite & $\mathrm{FeS}$ & 0.97 & 1.81 & - & 1.24 & 0.89 \\
\hline Manganite & $\mathrm{MnOOH}$ & -5.62 & -7.31 & -8.74 & -5.51 & - \\
\hline Melanterite & $\mathrm{FeSO}_{4}: 7 \mathrm{H}_{2} \mathrm{O}$ & -9.02 & -6.15 & - & -8.69 & -9.39 \\
\hline Pyrite & $\mathrm{FeS}_{2}$ & 25.42 & 24.72 & - & 25.66 & 25.47 \\
\hline Pyrochroite & $\mathrm{Mn}(\mathrm{OH})_{2}$ & -6.9 & -7.66 & -8.94 & -6.81 & - \\
\hline Pyrolusite & $\mathrm{MnO}_{2}: \mathrm{H}_{2} \mathrm{O}$ & -12.1 & -14.7 & -16.15 & -11.8 & - \\
\hline Quartz & $\mathrm{SiO}_{2}$ & 0.13 & 0.38 & 0.05 & 0.24 & 0.14 \\
\hline Rhodochrosite & $\mathrm{MnCO}_{3}$ & -0.98 & -1.32 & -2.41 & -0.78 & - \\
\hline Sepiolite & $\mathrm{Mg}_{2} \mathrm{Si}_{3} \mathrm{O}_{7} .5 \mathrm{OH}: 3 \mathrm{H}_{2} \mathrm{O}$ & -8.47 & -9.01 & -10.05 & -5.33 & -11.3 \\
\hline Sepiolite(d) & $\mathrm{Mg}_{2} \mathrm{Si}_{3} \mathrm{O}_{7} .5 \mathrm{OH}: 3 \mathrm{H}_{2} \mathrm{O}$ & -11.1 & -11.6 & -12.67 & -7.96 & -13.9 \\
\hline Siderite & $\mathrm{FeCO}_{3}$ & -0.7 & 0.26 & - & -0.27 & -0.9 \\
\hline $\mathrm{SiO} 2(\mathrm{a})$ & $\mathrm{SiO}_{2}$ & -1.21 & -0.96 & -1.29 & -1.1 & -1.19 \\
\hline Smithsonite & $\mathrm{ZnCO}_{3}$ & -7.41 & -7.39 & -7.5 & -7.67 & -7.41 \\
\hline Sphalerite & $\mathrm{ZnS}$ & 2.4 & 2.3 & 2.09 & 1.95 & 2.49 \\
\hline Strontianite & $\mathrm{SrCO}_{3}$ & -2.04 & -3.56 & -3.07 & -1.22 & - \\
\hline Sulfur & $\mathrm{S}$ & 12.26 & 10.72 & 10.53 & 12.26 & 12.44 \\
\hline Sylvite & $\mathrm{KCl}$ & -8.3 & -8.6 & -9.41 & -7.37 & -7.94 \\
\hline Talc & $\mathrm{Mg}_{3} \mathrm{Si}_{4} \mathrm{O}_{10}(\mathrm{OH})_{2}$ & -9.3 & -10.2 & -11.59 & -4.57 & -13.4 \\
\hline Willemite & $\mathrm{Zn}_{2} \mathrm{SiO}_{4}$ & -14.1 & -14.7 & -15.55 & -14.7 & -13.9 \\
\hline Witherite & $\mathrm{BaCO}_{3}$ & -3.25 & -4.22 & -5.01 & -2.08 & - \\
\hline $\mathrm{Zn}(\mathrm{OH}) 2(\mathrm{e})$ & $\mathrm{Zn}(\mathrm{OH})_{2}$ & -8.41 & -8.83 & -9.13 & -8.8 & -8.4 \\
\hline
\end{tabular}




\subsubsection{Water-Quality Assessment}

Only eight of the sampled water wells had no trace metals exceeding the EPA Primary or Secondary Drinking Water Regulations (Table 3). Concentrations of analytes exceeded these limits for three elements in three wells, two elements in eleven wells, and one element in two wells. Arsenic concentrations were above the Primary Drinking Water Regulations in one well during both the spring and fall sampling events. Secondary Drinking Water Regulations were surpassed for iron in 15 wells, manganese in 12 wells, aluminum in three wells, chloride in one well, and sulfate in one well.

High methane concentrations ( $>1 \mathrm{mg} / \mathrm{L}$; McMahon et al. (2017)) were found in 12 wells. Three wells were within the "Warning, Investigate" level $\left(10 \mathrm{mg} / \mathrm{L}<\mathrm{CH}_{4}<28\right.$ $\mathrm{mg} / \mathrm{L}$ ), and at least three wells had dissolved methane concentrations above the "Immediate Action" level (> $28 \mathrm{mg} / \mathrm{L})$ (Eltschlager et al., 2001). The method of collection may impact methane concentration results (Molofsky et al., 2016b). A comparison of nine pairs of samples collected through the direct fill-method in glass bottles and measured at KGS and collected in Isoflask $^{\mathrm{TM}}$ containers and measured at Isotech suggests that methane concentrations of samples measured by the first method might be underreported, especially at high concentrations. Therefore, Isotech results were used for methane data when available (Table 5). A linear regression suggests that some of the samples only measured at KGS might have methane concentrations up to $\sim 25 \%$ higher than measured (Figure 8 ). IsoFlask $^{\mathrm{TM}}$ containers have been previously identified to yield more accurate results, particularly at methane concentrations $>20 \mathrm{mg} / \mathrm{L}$ and in samples showing degassing (bubbling) (Molofsky et al., 2016b). However, analysis of temporal variations of methane in groundwater suggests that natural fluctuations in concentrations can range from 2.5 up 
to 6 times relative to the lowest recorded values (Rivard et al., 2018), adding additional sources of potential variability.

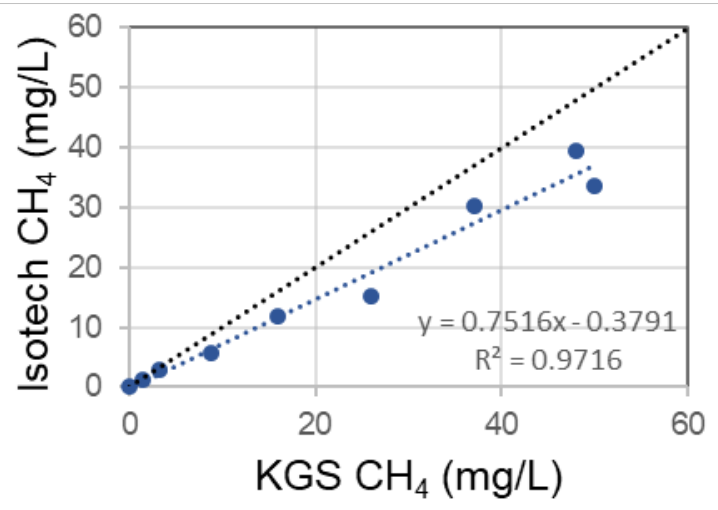

Figure 8. Comparison of methane concentrations between nine pairs of samples collected in glass bottles through the direct-fill method and analyzed at KGS and collected in Isoflask $^{\mathrm{TM}}$ containers and analyzed at Isotech. Black line represents 1:1 relationship, whereas dark blue line shows data trendline.

Interestingly, the record for a well $<200 \mathrm{~m}$ from sampled well A03 contained a site investigation report for an incident in 2011 when a methane concentration of $54.9 \mathrm{mg} / \mathrm{L}$ was measured. In that investigation, problematic concentrations of iron related bacteria, SRB, and slime forming bacteria were found (KGS, 2020).

\subsubsection{Geochemical Conditions Associated with Dissolved Methane}

Even though the most common water type sampled was $\mathrm{Ca}-\mathrm{HCO}_{3}$, the most common water type of samples with high methane concentrations $(>1 \mathrm{mg} / \mathrm{L})$ was $\mathrm{Na}-$ $\mathrm{HCO}_{3}$ (Figures 3 and 4), with high sodium, high chloride, high bicarbonate, and low sulfate concentrations. This is consistent with previous studies showing $\mathrm{Na}-\mathrm{HCO}_{3}, \mathrm{Na}-\mathrm{HCO}_{3}-\mathrm{Cl}$, and $\mathrm{Na}-\mathrm{Cl}$ groundwaters are more likely to have elevated methane (Humez et al., 2016; Molofsky et al., 2013; Zhu et al., 2018). Groundwaters with high sodium and chloride concentrations have been associated, based on chemical and isotopic composition, with longer and deeper flowpaths, higher cation exchange, sulfate reduction, mixing with brines 
and locations close to valley bottoms (Molofsky et al., 2016a; Wunsch, 1993). In contrast, groundwaters with high calcium and magnesium concentrations have been associated with dissolution of calcite, oxidation of pyrite, and locations close to ridgetops (Wunsch, 1993; Zhu et al., 2018). Methane concentrations have been associated with topography of ridgetops more than valleys in the Appalachian Basin (Molofsky et al., 2016a).

As expected from microbial processes, samples with elevated methane have no sulfate because the occurrence of sulfate inhibits methanogenesis. In samples with sulfate, the most likely sulfate source is the oxidation of sulfide minerals, such as pyrite, which releases sulfate and hydrogen ions to groundwater and precipitates amorphous iron hydroxide:

Pyrite oxidation: $\quad \mathrm{FeS}_{2}(\mathrm{~s})+3.75 \mathrm{O}_{2} \rightarrow \mathrm{Fe}(\mathrm{OH})_{3}(\mathrm{~s})+2 \mathrm{SO}_{4}{ }^{2-}+4 \mathrm{H}^{+}$

Other potential sulfate sources, such as evaporites, are not present in eastern Kentucky (Wunsch, 1993).

\subsection{Isotopic Composition and Geochemical Processes}

\subsubsection{Methane Sources, Methanogenesis and Oxidation of Methane}

Assessment of methane sources and interactions follows binary genetic diagrams defined in Milkov and Etiope (2018) among $\delta^{13} \mathrm{C}-\mathrm{CH}_{4}, \delta^{2} \mathrm{H}-\mathrm{CH}_{4}, \delta^{13} \mathrm{C}-\mathrm{CO}_{2}$, and gas ratios, $\mathrm{C}_{1} /\left(\mathrm{C}_{2}+\mathrm{C}_{3}\right)$. These diagrams (Figures 9,10 and 11) define the genetic fields for methane sources (primary microbial- $\mathrm{CO}_{2}$ reduction, primary microbial-fermentation, thermogenic, secondary microbial, and abiotic) and identify processes affecting isotopic composition (biodegradation, maturity, migration, mixing, oxidation, and thermochemical sulfate reduction). Most wells have a methane signature consistent with a microbial source, and the rest might have a thermogenic influence or have been affected by a secondary process 
in at least one of the genetic diagrams. No water well shows an abiotic signature in either of the genetic diagrams.

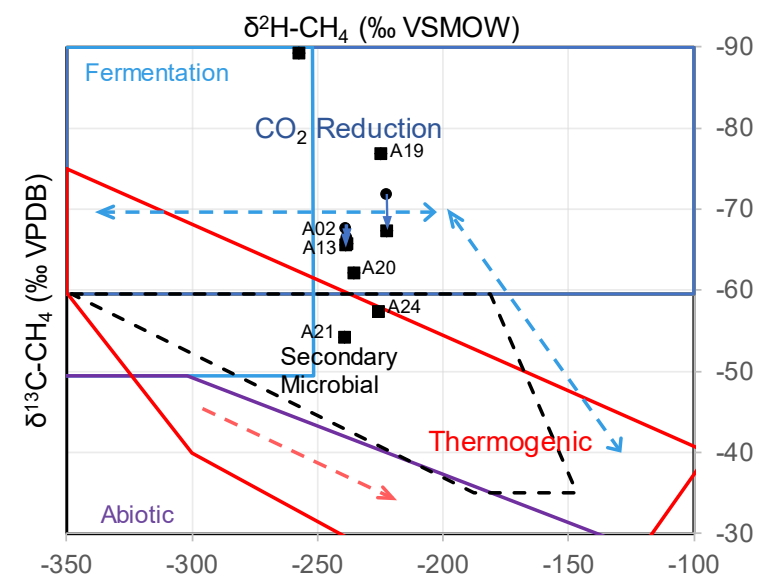

Figure 9. Genetic diagram of $\delta^{13} \mathrm{C}-\mathrm{CH}_{4}$ vs $\delta^{2} H-\mathrm{CH}_{4}$ for eleven samples from seven wells, including data for three wells sampled in two sampling events shown with blue arrows. The blue dashed lines represent microbial-thermogenic transition/mixing. The red dashed line represents the change in composition with increasing thermal maturity.

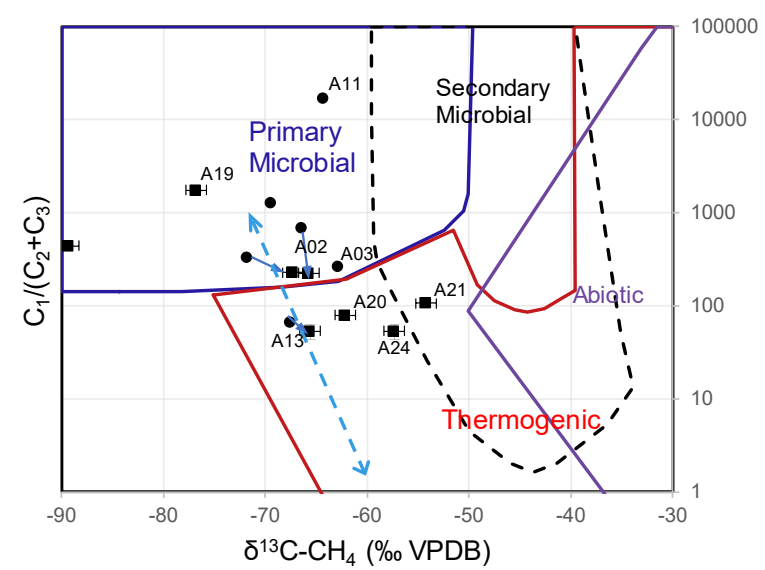

Figure 10. Genetic diagram of $\delta^{13} C-\mathrm{CH}_{4}$ vs $\mathrm{C}_{1} /\left(\mathrm{C}_{2}+\mathrm{C}_{3}\right)$ for fourteen samples from eleven wells, including data for three wells sampled in two sampling events. Blue dashed line represents microbial-thermogenic transition/mixing. 


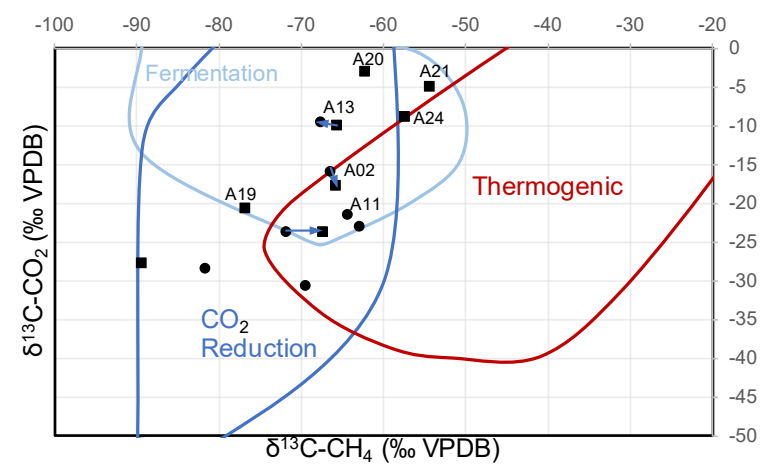

Figure 11. Genetic diagram of $\delta^{13} C-\mathrm{CH}_{4}$ vs. $\delta^{13} C-\mathrm{CO}_{2}$ values for fifteen samples from twelve wells, including data for three wells sampled in two sampling events.

The $\delta^{13} \mathrm{C}-\mathrm{CH}_{4}$ vs. $\delta^{2} \mathrm{H}-\mathrm{CH}_{4}$ genetic diagram (Figure 9) suggests that six out of eight wells with data have a "primary microbial- $\mathrm{CO}_{2}$ reduction" $(\mathrm{CR})$ source of methane (blue field). Similarly, the gas ratios $\left(\mathrm{C}_{1} /\left(\mathrm{C}_{2}+\mathrm{C}_{3}\right)\right)$ and $\delta^{13} \mathrm{C}-\mathrm{CH}_{4}$ values (Figure 10) suggest a CR source (blue field) for seven out of 11 wells with data. Most samples (10 out of 12) in the genetic diagram of $\delta^{13} C-\mathrm{CO}_{2}$ and $\delta^{13} C-\mathrm{CH}_{4}$ (Figure 11) show a $\mathrm{CR}$ source signature (blue field). A few samples also coincide with a "primary microbial-fermentation" source of methane (light blue field). However, none of those samples have $\delta^{2} H-\mathrm{CH}_{4}$ values indicative of a fermentation signature. Five of these wells fall in both the CR and early mature thermogenic (EMT) source fields. However, they are likely to be only or mainly from a CR source, as these samples overlap the CR source signature in the genetic diagrams for $\delta^{13} \mathrm{C}-\mathrm{CH}_{4}$ vs. $\delta^{2} \mathrm{H}-\mathrm{CH}_{4}$ (Figure 9) (for the three samples with data available) and $\mathrm{C}_{1} /$ $\left(\mathrm{C}_{2}+\mathrm{C}_{3}\right)$ vs. $\delta^{13} \mathrm{C}-\mathrm{CH}_{4}$ (Figure 10) (all five samples). Two samples had signatures consistent with an EMT source on all genetic diagrams, and two other samples were indicative of a CR source on two genetic diagrams and of an EMT source on one genetic diagram. The two samples with signatures of both EMT and CR sources (A13 and A20) could be the product of a secondary process such as mixing of a biogenic source with a thermogenic 
source that increased the concentrations of ethane and propane and decreased the gas ratios $\left(\mathrm{C}_{1} /\left(\mathrm{C}_{2}+\mathrm{C}_{3}\right)\right)$ without affecting the $\delta^{13} C-\mathrm{CH}_{4}$ and $\delta^{2} H-\mathrm{CH}_{4}$ values.

Two wells (A21 and A24) have $\delta^{13} C-\mathrm{CH}_{4}$ and $\delta^{2} H-\mathrm{CH}_{4}$ values that overlap with the signatures for EMT and secondary microbial (SM) sources (red and black fields, respectively, in Figure 9). However, gases from SM sources have $\delta^{13} C-\mathrm{CO}_{2}$ values $>+2 \%$ (Milkov and Etiope, 2018) and no sample in this study shows a $\delta^{13} C-\mathrm{CO}_{2}$ value $>-2.9 \%$. Therefore, these two samples are likely from an EMT source. On a $\mathrm{C}_{1} /\left(\mathrm{C}_{2}+\mathrm{C}_{3}\right)$ vs. $\delta^{13} C$ $\mathrm{CH}_{4}$ genetic diagram, they have a slightly lower ratio compared to gases from $\mathrm{CR}$, consistent with the EMT source signature (red field on Figure 10) where ethane and propane occur in greater concentrations than in gas produced by $\mathrm{CR}$. The observed values are isotopically lighter as compared to late mature thermogenic (LMT) gas. Increasing values for $\delta^{13} \mathrm{C}-\mathrm{CH}_{4}, \delta^{2} \mathrm{H}-\mathrm{CH}_{4}$, and $\delta^{13} \mathrm{C}-\mathrm{CO}_{2}$ suggest increasing maturity, as more positive values from the kerogen are incorporated (Milkov and Etiope, 2018; Whiticar, 1999). These two samples fall between the fields of CR and EMT sources on the $\delta^{13} C-\mathrm{CO}_{2}$ vs. $\delta^{13} \mathrm{C}-\mathrm{CH}_{4}$ genetic diagram (Figure 11). Therefore, methane could reflect mixing of $\mathrm{CR}$ and EMT sources and a secondary process affecting the isotopic signature of methane, such as methane oxidation:

Methane oxidation: $\quad \mathrm{CH}_{4}(\mathrm{aq})+3 \mathrm{H}_{2} \mathrm{O}->\mathrm{HCO}_{3}^{-}+9 \mathrm{H}^{+}+8 \mathrm{e}^{-}$

Methane concentrations and $\delta^{13} C$-DIC values were used to further characterize possible influences on gas composition in wells showing methanogenesis. $\mathrm{As}^{\mathrm{CO}_{2}}$ is consumed to produce methane, the remaining DIC becomes enriched in $\delta^{13} C$ due to preferential use of ${ }^{12} \mathrm{C}$. Therefore, $\delta^{13} \mathrm{C}$-DIC values should be positively correlated with methane concentrations. Most wells with methane $>1 \mathrm{mg} / \mathrm{L}$ follow a trendline consistent 
with methanogenesis through CR (blue arrow on Figure 12). However, four samples from three wells (A13, A20, and A21), including data for one well sampled in two sampling events, fall above this trendline (red arrow on Figure 12) and two wells (A11 and A19) fall below (gray arrow on Figure 12). A steeper relationship between methane concentrations and $\delta^{13} C$-DIC could be evidence for methanogenesis mixing with an additional thermogenic methane source that does not change $\delta^{13} C$-DIC values, whereas a reduced slope could reflect the oxidation of methane. The three wells above the trendline were identified as thermogenic on the $\mathrm{C}_{1} /\left(\mathrm{C}_{2}+\mathrm{C}_{3}\right)$ vs. $\delta^{13} \mathrm{C}-\mathrm{CH}_{4}$ genetic diagram (Figure 10), supporting the concept of a mixed influence from a thermogenic source. The two wells below the trendline have microbial signatures on the genetic diagrams and contain sulfate, which could be evidence of a dynamic system where methane oxidation follows methanogenesis. Mixing and oxidation processes appear to be occurring to some extent in at least some of these wells.

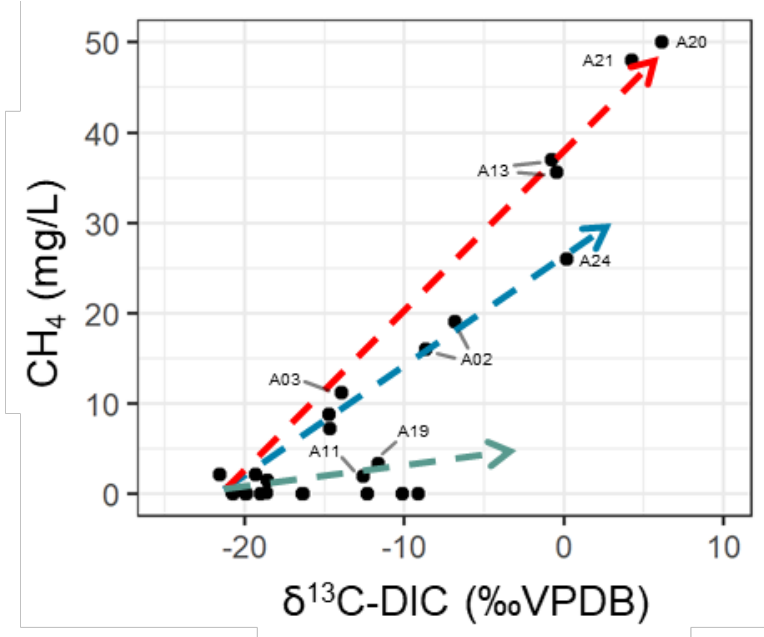

Figure 12. $\mathrm{CH}_{4}$ concentrations vs. $\delta^{13} C$-DIC values. A trend of increasing methane concentration with increasing $\delta^{13} C$-DIC, possibly due to methanogenesis, can be pointed out in a subset of samples (blue arrow). Three wells appear to follow a steeper trend (red arrow), and two wells a shallower one (gray arrow), possibly due to an extra input of methane and methane oxidation, respectively. 


\subsubsection{Sulfate Sources and Bacterial Sulfate Reduction}

Predominant redox processes in groundwater can be inferred from the concentrations of electron acceptors, and products (Chapelle et al., 2009; McMahon and Chapelle, 2008). Methanogenesis occurs primarily in environments with zero to little sulfate (Flynn et al., 2013; Humez et al., 2016; Molofsky et al., 2016a). Therefore, complementary redox processes and zones can be inferred from the distribution of methane or sulfate in groundwater where chemistry is dominated by microbial metabolism. Given the antithetic relationship, the distribution of sulfate, its sources, and geochemical interactions were also investigated using $\delta^{34} S-\mathrm{SO}_{4}, \delta^{18} O-\mathrm{SO}_{4}$, and sulfate concentrations. The values of $\delta^{34} S-\mathrm{SO}_{4}$ and $\delta^{18} \mathrm{O}-\mathrm{SO}_{4}$ in wells with sulfate coincide with commonly observed ranges for industrial/atmospheric deposition in three wells, sulfate derived from the oxidation of sulfur in four wells, and soil sulfate in one well (Figure 13) (Krouse and Mayer, 2000). Four wells overlap an evaporite signature (Figure 13). However, evaporite deposits are not common in this area. Another well (A11), which does not correspond to any source, has the most positive $\delta^{34} S-\mathrm{SO}_{4}$ and $\delta^{18} O-\mathrm{SO}_{4}$ values. Samples from these last five wells (dark red circle in Figure 13) likely reflect BSR, a process that results in a simultaneous enrichment of $\delta^{34} S-\mathrm{SO}_{4}$ and $\delta^{18} \mathrm{O}-\mathrm{SO}_{4}$ as the remaining sulfate becomes enriched in the heavier isotopes (Krouse and Mayer, 2000). Both the positive correlation of $\delta^{34} S$-SO $\mathrm{SO}_{4}$ and $\delta^{18} \mathrm{O}-\mathrm{SO}_{4}$ (Figure 13) and the increase in $\delta^{34} S$-SO $\mathrm{SO}_{4}$ with decreasing sulfate concentrations (dark arrows in Figure 14) support the inference of BSR for these wells. 


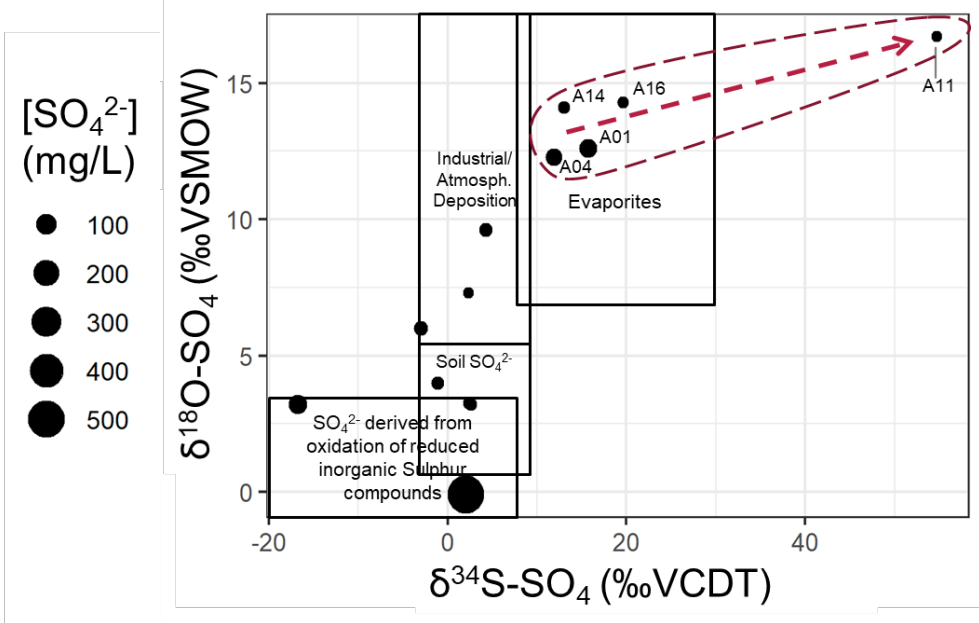

Figure 13. $\delta^{34} S-\mathrm{SO}_{4}$ vs. $\delta^{18} O-\mathrm{SO}_{4}$ values. Boxes represent common $\delta^{34} S$ and $\delta^{18} O$ values for sulfate sources (Krouse and Mayer, 2000). Red dashed line is a representation of the trend observed for bacterial sulfate reduction.

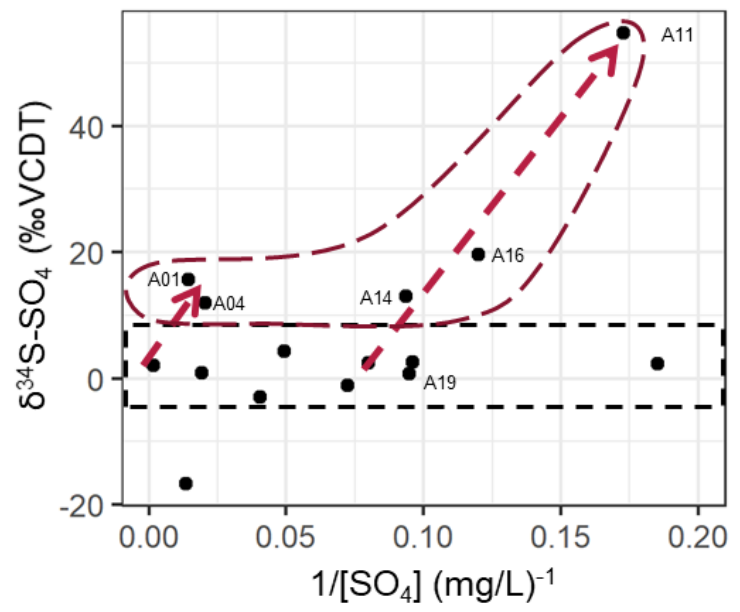

Figure 14. $\delta^{34} S-\mathrm{SO}_{4}$ vs. the inverse concentration of sulfate. Samples with a single source of sulfate have the same signature regardless of concentration (black box), whereas samples that have gone through bacterial sulfate reduction follow a trend of more positive $\delta^{34} S-\mathrm{SO}_{4}$ values with decreasing sulfate concentrations (dark red arrows).

Sulfate sources can be refined by considering the regional geology. Pyrite oxidation is the only readily available sulfate source in eastern Kentucky; pyrite can often be found in coals and other sedimentary rocks and gypsum deposits are not common (Wunsch, 1993). Coal in eastern Kentucky has a low to medium sulfur content (0.7 to $3.1 \%)$ with a wide range of pyrite $\delta^{34} S$-SO 4 values (-16.6\% to 28.6\%o) (Elswick et al., 2007). This range 
is consistent with most values observed in this study (Table 5, Figure 13), though the $\delta^{34} S$ $\mathrm{SO}_{4}$ values do not unequivocally define a distinctive sulfate source. Little $(\sim-0.7 \%)$ to no fractionation of sulfur isotopes has been identified from pyrite oxidation under anaerobic or aerobic conditions (Balci et al., 2007; Krouse and Mayer, 2000). Additionally, anthropogenic activities (combustion and refining processes of coal, oil, and gas) emit $\mathrm{SO}_{2}$ gas and can introduce atmospheric/anthropogenic sulfate into groundwater through recharge from precipitation (Krouse and Mayer, 2000). Anthropogenic/industrial sources can represent more than two-thirds of the sulfate in atmospheric deposition in industrialized regions (Krouse and Mayer, 2000).

\subsection{Redox Geochemical Interactions Between Methane and Sulfate}

Methanogenesis and BSR have been generally considered competing processes following a thermodynamic hierarchy, in which the latter is preferentially catalyzed by microorganisms due to having a higher energy output—assuming sulfate availability—as compared to the former. The two reactions are part of a series of possible redox reactions with each having its own release of energy and therefore favorability. However, microbial reactions in the subsurface are controlled by several factors beyond the thermodynamic concept; more than one redox process can happen at a time and location given the right chemical and environmental conditions (Bethke et al., 2011).

Values of $\delta^{13} C$-DIC, sulfate and methane concentrations can be used to identify BSR and methanogenic processes. As sulfate is reduced, its concentration decreases and $\delta^{13} C$-DIC would become more negative (dark red arrow in Figure 15):

Sulfate reduction: $\quad \mathrm{SO}_{4}^{2-}+\mathrm{CH}_{3} \mathrm{COO}_{-}^{-}-\mathrm{HS}^{-}+2 \mathrm{HCO}_{3}^{-}$ 
Once wells have no sulfate, a methanogenic trend with increasing concentrations of methane and more positive $\delta^{13} C$-DIC values is established (blue arrow in Figure 15). Wells between these trends with methane or sulfate would be representative of the addition of sulfate intermittently with methanogenesis. This could potentially occur due to increased weathering of pyrite and other sulfide minerals from mining activities.

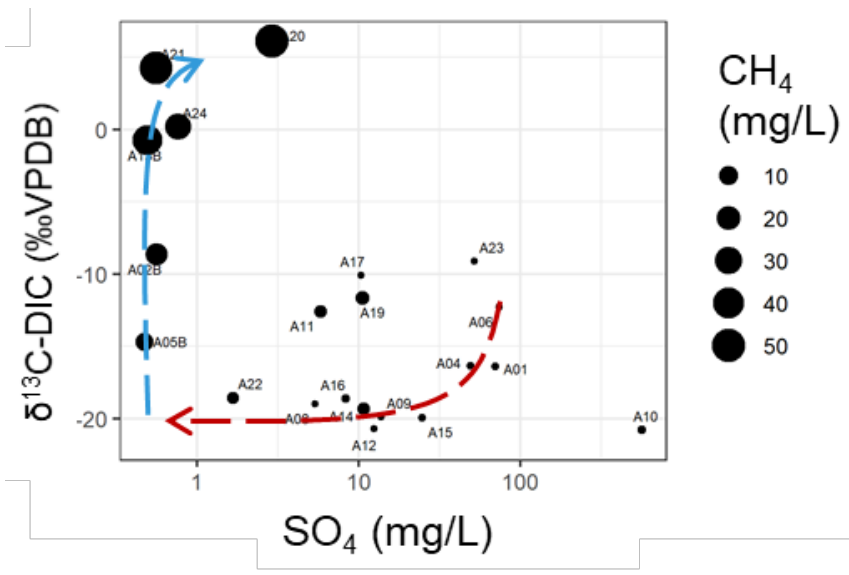

Figure 15. Evolution of $\delta^{13} C$-DIC values compared to sulfate concentrations. Blue dashed line represents methanogenesis trend. Red dashed line represents the trend of sulfate reduction. Samples in between these trendlines potentially have mixed processes.

Two wells (A11 and A19) had both dissolved gas and sulfate, with methane from a microbial source according to a genetic diagram (Figure 10), and are suspected to show methane oxidation due to lower concentrations of methane compared to $\delta^{13} C$-DIC (Figure 12). These wells plot between the identified trends for sulfate reduction and methanogenesis in Figure 15, and one of these wells (A11) also showed the most reduced signature for sulfate in the plots of $\delta^{34} \mathrm{~S}_{-} \mathrm{SO}_{4}$ vs. inverse concentration of sulfate (Figure 14) and of $\delta^{34} \mathrm{~S}_{-} \mathrm{SO}_{4}$ vs. $\delta^{18} \mathrm{O}-\mathrm{SO}_{4}$ (Figure 13). Therefore, in at least one well (A11), the predominant redox process is likely local methane oxidation (MO) coupled with BSR:

$$
\mathrm{MO}+\mathrm{BSR}: \quad \mathrm{CH}_{4}(\mathrm{aq})+\mathrm{SO}_{4}{ }^{2-} \rightarrow \mathrm{HCO}_{3}{ }^{-}+\mathrm{HS}^{-}+\mathrm{H}_{2} \mathrm{O}
$$


This coupling has been hypothesized to reflect a syntrophic partnership with methanogens in a pristine heterogeneous aquifer with microenvironments with varying redox conditions (Flynn et al., 2013). Additionally, it occurs in areas affected by fugitive gas from oil and gas wells and the migration of methane from coalbed methane operations (Flynn et al., 2013; Van Stempvoort et al., 2005; Wolfe and Wilkin, 2017). The coupling of methane oxidation and BSR could also potentially explain the observation of a $\mathrm{H}_{2} \mathrm{~S}$ smell in two wells (A13 and A21) with high methane concentrations and close to no sulfate.

\subsection{Spatial and Environmental Conditions Associated with Dissolved Methane}

As one of the main goals of this study was to understand the role of mining and oil and gas development in groundwater methane occurrence, the area within a 1-km radius surrounding each water well sampled was assessed for extent of mining and oil and gas development. Mining was divided into categories based on the percentage of area covered, where low influence is $<33 \%$ and high influence is $>67 \%$. The number of oil and gas wells were counted and grouped into three groups with $<10$ wells, 10-20 wells, and $>20$ wells. Box-and-whisker plots were plotted to analyze water chemistry as a function of mining or oil and gas influence (Figure 16). 

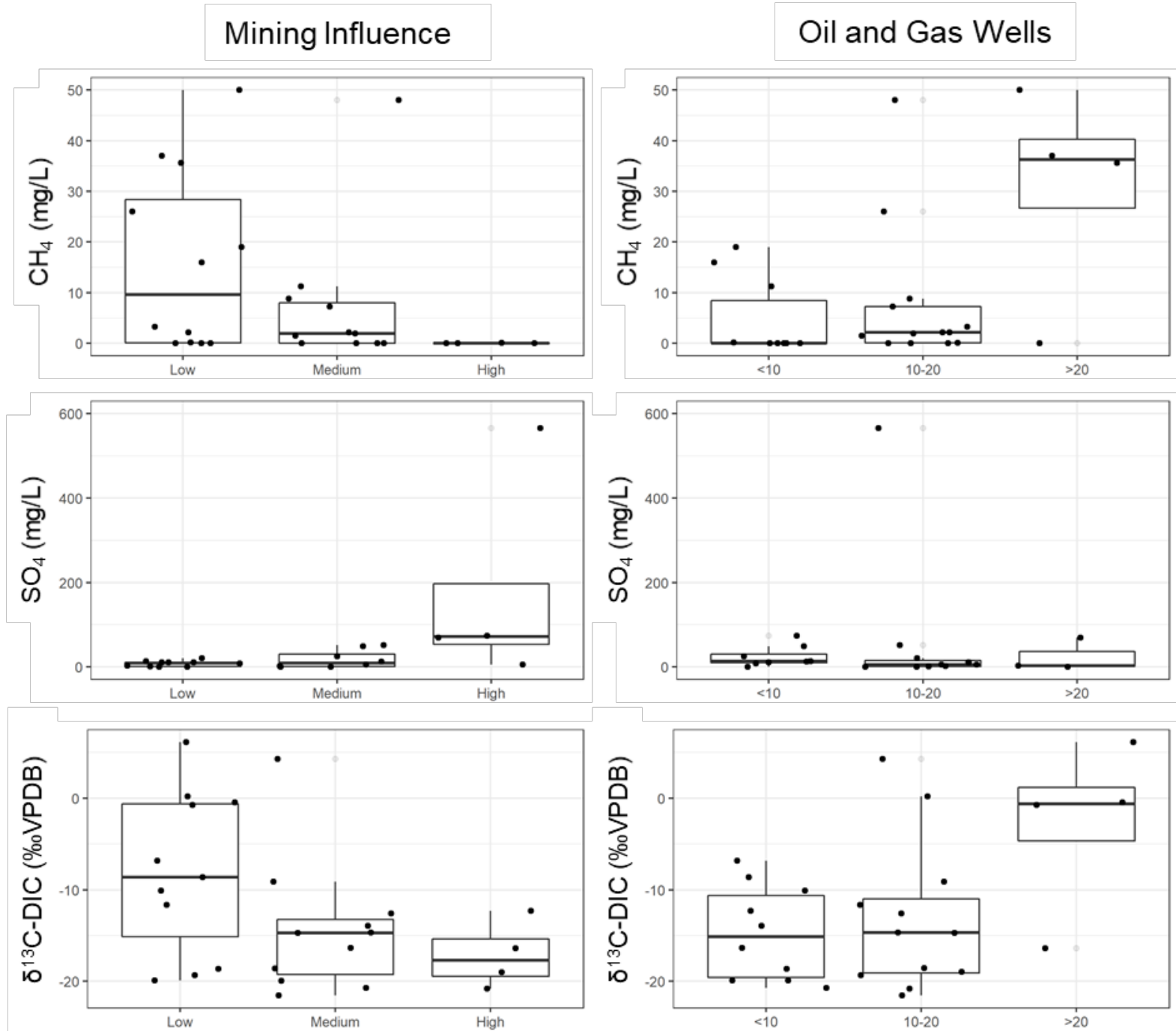

Figure 16. Box-and-whisker plot of the distribution of water chemistry in areas with mining influence and oil and gas wells. The box contains the second and third quartiles and the bold middle line represents the median. Lower and upper error lines represent maximum and minimum values excluding potential outliers. Data points are scattered within each category.

Sulfate concentrations appear to be associated more with nearby mining, whereas methane appears to be associated with both nearby mining and oil and gas (Figures 16 and 17. Wells in areas with high mining influence $(>67 \%)$ have a median sulfate concentration higher than areas with low to medium influence, which is consistent with mining being the main source of sulfate through the oxidation of pyrite. On the other hand, areas with low mining influence $(<33 \%)$ have a higher median methane concentration and more positive 
$\delta^{13} \mathrm{C}$-DIC values than areas with medium or high mining influence. Water wells in areas with a high density of oil and gas ( $>20$ wells) appear to have slightly higher methane concentrations than water wells in areas with low or medium density. These water wells have a microbial source signature in at least two genetic diagrams (Figures 9 and 10). However, two of these wells (A13 and A20) also appeared to show a mixture of methane sources by intersecting a thermogenic signature in the genetic diagram of gas ratios $\left(\mathrm{C}_{1} /\right.$ $\left(\mathrm{C}_{2}+\mathrm{C}_{3}\right)$ ) and $\delta^{13} \mathrm{C}-\mathrm{CH}_{4}$ (Figure 10), as well as following a steeper trend for methane concentrations compared to $\delta^{13} C$-DIC values (Figure 12). Similarly, the two water wells (A21 and A24) with the highest methane concentrations in the area with medium density of oil and gas (10-20 wells) are consistent with both CR and EMT sources (Figures 9, 10 and 11). Therefore, mixing of microbial methane with thermogenic methane appears to be more likely in areas with medium to high density of oil and gas development ( $>10$ wells within a $1-\mathrm{km}$ radius). 


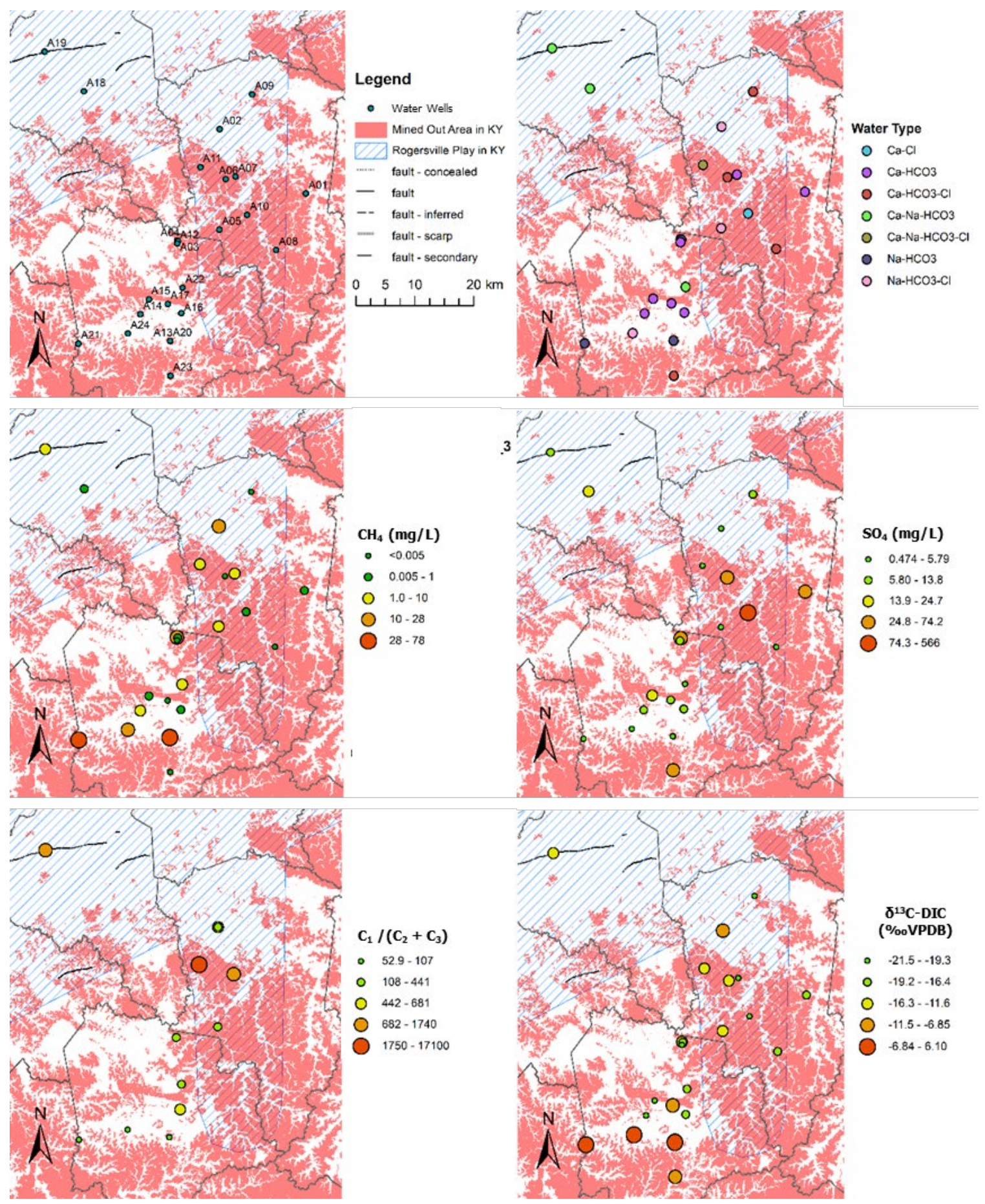

Figure 17. Water chemistry maps of the sampled wells.

\section{CONCLUSIONS}

Geochemical conditions for methanogenesis and sulfate reduction appear to be prevalent and interconnected in eastern Kentucky groundwater. High methane 
concentrations $(>1 \mathrm{mg} / \mathrm{L})$ were detected in 12 out of 24 wells sampled, and the main methane source has been identified as $\mathrm{CO}_{2}$-reduction methanogenesis by using bivariate plots with $\delta^{13} C-\mathrm{CH}_{4}, \delta^{2} H-\mathrm{CH}_{4}, \delta^{13} \mathrm{C}-\mathrm{CO}_{2}$, and gas ratios $\mathrm{C}_{1} /\left(\mathrm{C}_{2}+\mathrm{C}_{3}\right)$ as variables. Methane concentrations are reduced in areas with high sulfate concentrations, which are associated with pyrite oxidation. Decreasing sulfate concentrations associated with more positive ${ }^{34} \mathrm{~S}_{-} \mathrm{SO}_{4}$ and $\delta^{18} \mathrm{O}$-SO 4 values in groundwater provide evidence of sulfate-reducing conditions in some areas. One well with a high methane concentration $(1.9 \mathrm{mg} / \mathrm{L})$ and some sulfate $(5.8 \mathrm{mg} / \mathrm{L})$ shows evidence of both sulfate reduction and methane oxidation. Additionally, at least two wells appear to have a thermogenic influence on top of microbial methanogenesis due to methane concentrations exceeding concentrations expected from a methanogenesis-only trend when compared with $\delta^{13} \mathrm{C}-\mathrm{CO}_{2}$ values. Figure 18 illustrates the potential migration pathways leading to the methane compositions observed in this area.

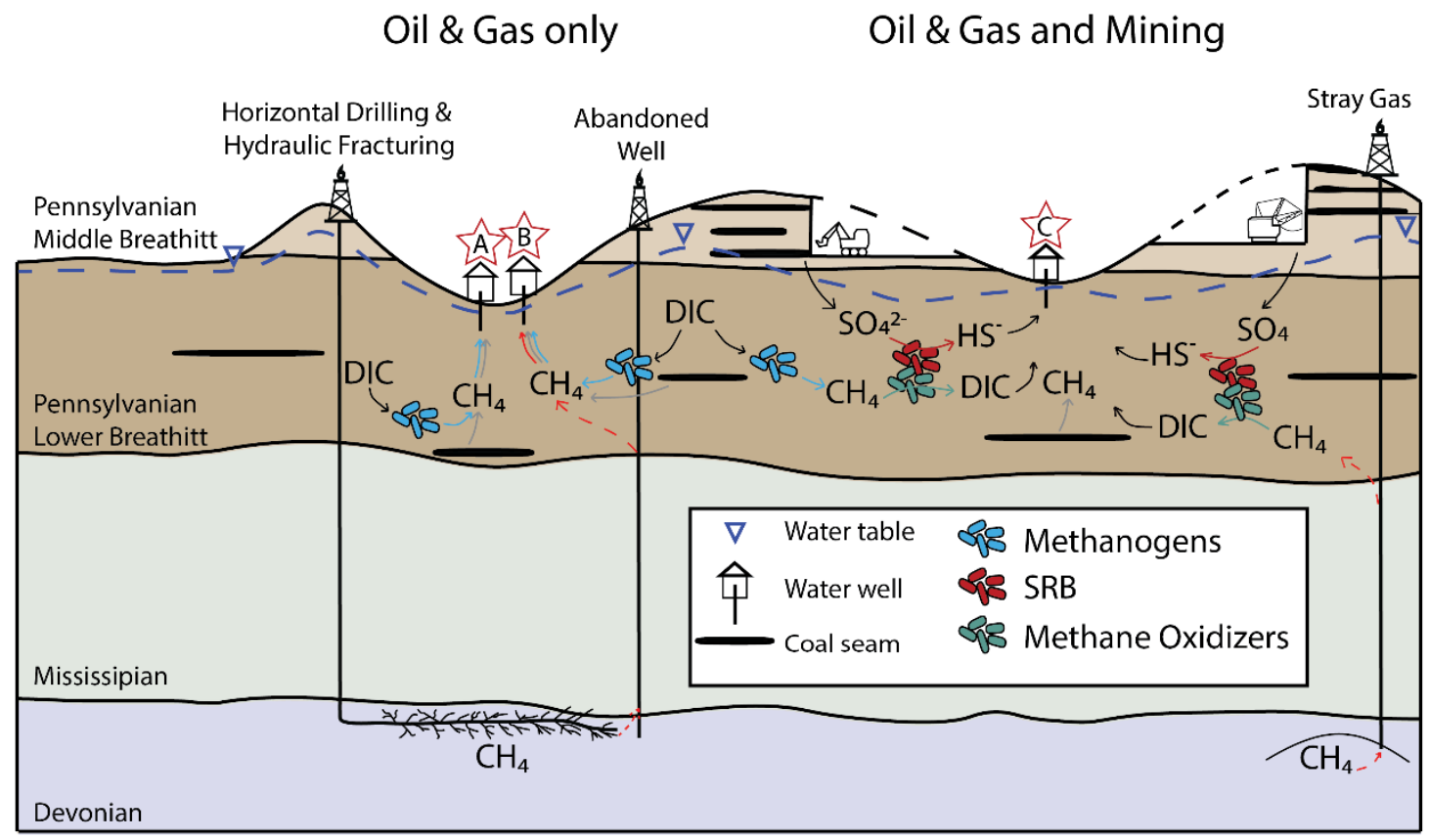

Figure 18. Schematic cross-section of the geochemical processes most relevant to methane in eastern Kentucky in relation to fossil fuel development influences. Methane pathways are indicated by arrows and color indicates source, where blue is microbial, red is 
thermogenic, and gray is other. Blue dashed line represents groundwater table. Well A shows CR methanogenesis, and it also considers a secondary source from coal. Well B shows a mixture of $\mathrm{CR}$ methanogenesis and thermogenic sources. Well $\mathrm{C}$ shows no methane in the well, while BSR and methane oxidation can occur nearby.

This study identifies how the distribution of methane and sulfate in groundwater and the geochemical processes affecting their distribution relate to the spatial distribution of mining and oil and gas development in eastern Kentucky. Derived primarily from microbial sources, methane in groundwater is a common occurrence. However, methane can be oxidized in sulfate-reducing conditions where mining has created sulfate-rich waters. The oxidation of methane is perhaps most evident in southeastern Kentucky, an area with high mining influence, where methane concentrations are $<10 \mathrm{mg} / \mathrm{L}$ (LeDoux et al., 2016). In contrast, northeastern Kentucky has limited mining and methane concentrations can be up to $78 \mathrm{mg} / \mathrm{L}$ (Zhu et al., 2018). The study area for this project encompasses zones with different degrees of mining influence, and methane concentrations were up to $50 \mathrm{mg} / \mathrm{L}$. Areas with a high mining influence have low methane concentrations and geochemical processes similar to the ones identified in LeDoux et al. (2016). On the other hand, areas with a low mining influence have high methane concentrations controlled by $\mathrm{CO}_{2}$-reduction methanogenesis, and resemble observations in Zhu et al. (2018).

Areas with higher oil and gas development appear to be more likely to introduce thermogenic methane and stimulate mixing with microbial methane. This is consistent with observations of increased methane concentrations close to oil and gas development in the Marcellus Shale (Jackson et al., 2013; Osborn et al., 2011). Therefore, future fossil fuel development in eastern Kentucky should record pre-drilling concentrations of dissolved gases and their isotopic composition $\left(\delta^{13} \mathrm{C}-\mathrm{CH}_{4}, \delta^{2} H-\mathrm{CH}_{4}, \delta^{13} \mathrm{C}-\mathrm{CO}_{2}\right)$ to investigate possible methane leakage. In addition, the record of mining and oil and gas development 
should be considered, as it appears to have a significant effect on the active geochemical and redox processes affecting environmental conditions.

This study expands baseline data for groundwater geochemistry and dissolved methane in eastern Kentucky. Combined with previous work (e.g. LeDoux et al, 2016; Zhu et al., 2018), a broad fairway of groundwater characterization now extends from northeast to southeast Kentucky. Further insights into data from this and previous studies could benefit from a closer examination of the local hydrogeology, particularly as it relates to sulfur sources in Pennsylvanian aquifers. Redox interactions involving intermediate sulfur species should be investigated. Future groundwater sampling should target areas with data gaps, and monitor wells where more than one redox process or methane source has been identified to further differentiate the spatial distribution of redox environments in the subsurface, and the transport of sulfate and methane. Bacterial and archaeal microbial populations in sediments and groundwater should be investigated along with water chemistry to corroborate reducing and oxidizing processes recognized through chemical and isotopic signatures. 


\section{REFERENCES}

Adgate, J. L., Goldstein, B. D., and McKenzie, L. M., 2014, Potential Public Health Hazards, Exposures and Health Effects from Unconventional Natural Gas Development: Environmental Science \& Technology, v. 48, no. 15, p. 8307-8320.

Alvarez, R. A., Zavala-Araiza, D., Lyon, D. R., Allen, D. T., Barkley, Z. R., Brandt, A. R., Davis, K. J., Herndon, S. C., Jacob, D. J., Karion, A., Kort, E. A., Lamb, B. K., Lauvaux, T., Maasakkers, J. D., Marchese, A. J., Omara, M., Pacala, S. W., Peischl, J., Robinson, A. L., Shepson, P. B., Sweeney, C., Townsend-Small, A., Wofsy, S. C., and Hamburg, S. P., 2018, Assessment of methane emissions from the U.S. oil and gas supply chain: Science, v. 361, no. 6398, p. 186-188.

Balci, N., Shanks, W. C., Mayer, B., and Mandernack, K. W., 2007, Oxygen and sulfur isotope systematics of sulfate produced by bacterial and abiotic oxidation of pyrite: Geochimica et Cosmochimica Acta, v. 71, no. 15, p. 3796-3811.

Bethke, C. M., Sanford, R. A., Kirk, M. F., Jin, Q., and Flynn, T. M., 2011, The thermodynamic ladder in geomicrobiology: American Journal of Science, v. 311, no. 3, p. 183-210.

Carmody, R. W., Plummer, N., Busenberg, E., and Coplen, T. B., 1998, Methods for collection of dissolved sulfate and sulfide and analysis of their sulfur isotopic composition, 97-234

Chapelle, F. H., Bradley, P. M., Thomas, M. A., and McMahon, P. B., 2009, Distinguishing Iron-Reducing from Sulfate-Reducing Conditions: Groundwater, v. 47 , no. 2 , p. $300-305$.

Claire Botner, E., Townsend-Small, A., Nash, D. B., Xu, X., Schimmelmann, A., and Miller, J. H., 2018, Monitoring concentration and isotopic composition of methane in groundwater in the Utica Shale hydraulic fracturing region of Ohio: Environmental Monitoring and Assessment, v. 190, no. 6, p. 322.

Clark, I. D., and Fritz, P., 1997, Environmental isotopes in hydrogeology, Boca Raton, FL : CRC Press/Lewis Publishers, $352 \mathrm{p}$.

Colborn, T., Schultz, K., Herrick, L., and Kwiatkowski, C., 2014, An Exploratory Study of Air Quality Near Natural Gas Operations: Human and Ecological Risk Assessment: An International Journal, v. 20, no. 1, p. 86-105.

Craig, H., 1961, Isotopic Variations in Meteoric Waters: Science, v. 133, no. 3465, p. $1702-1703$.

Darrah, T. H., Vengosh, A., Jackson, R. B., Warner, N. R., and Poreda, R. J., 2014, Noble gases identify the mechanisms of fugitive gas contamination in drinking-water wells overlying the Marcellus and Barnett Shales: Proceedings of the National Academy of Sciences, v. 111, no. 39, p. 14076-14081.

Deutsch, W. J., 1997, Groundwater Geochemistry: Fundamentals and Applications to Contamination, Taylor \& Francis, $232 \mathrm{p}$

Ellis, B., Bone, G., and James, R., 2016, Kentucky Coal Facts: 16th Edition: Kentucky Energy and Environmental Cabinet, $127 \mathrm{p}$.

Elswick, E. R., Hower, J. C., Carmo, A. M., Sun, T., and Mardon, S. M., 2007, Sulfur and carbon isotope geochemistry of coal and derived coal-combustion byproducts: An example from an Eastern Kentucky mine and power plant: Applied Geochemistry, v. 22, no. 9, p. 2065-2077. 
Eltschlager, K. K., Hawkins, J. W., Ehler, W. C., and Baldassare, F., 2001, Technical measures for the investigation and mitigation of fugitive methane hazards in areas of coal mining: Office of Surface Mining Reclamation and Enforcement, Appalachian Regional Coordinating Center, 125 p.

Flynn, T. M., Sanford, R. A., Ryu, H., Bethke, C. M., Levine, A. D., Ashbolt, N. J., and Santo Domingo, J. W., 2013, Functional microbial diversity explains groundwater chemistry in a pristine aquifer: BMC Microbiology, v. 13, no. 1, p. 146.

Hammond, P. A., Wen, T., Brantley, S. L., and Engelder, T., 2020, Gas well integrity and methane migration: evaluation of published evidence during shale-gas development in the USA: Hydrogeology Journal, v. 28, no. 4, p. 1481-1502.

Harris, D. C., Hickman, J. B., and Eble, C. F., 2016, Cambrian Rogersville Shale (Conasauga Group), Kentucky and West Virginia: A potential new unconventional reservoir in the Appalachian Basin: Search and Discovery Online Journal, p. \#10787.

Hower, J. C., and Rimmer, S. M., 1991, Coal rank trends in the Central Appalachian coalfield: Virginia, West Virginia, and Kentucky: Organic Geochemistry, v. 17, no. 2, p. 161-173.

Humez, P., Mayer, B., Nightingale, M., Becker, V., Kingston, A., Taylor, S., Bayegnak, G., Millot, R., and Kloppmann, W., 2016, Redox controls on methane formation, migration and fate in shallow aquifers: Hydrology and Earth System Sciences, v. 20, no. 7, p. 2759-2777.

Jackson, R. B., Vengosh, A., Darrah, T. H., Warner, N. R., Down, A., Poreda, R. J., Osborn, S. G., Zhao, K., and Karr, J. D., 2013, Increased stray gas abundance in a subset of drinking water wells near Marcellus shale gas extraction: Proceedings of the National Academy of Sciences, v. 110, no. 28, p. 11250-11255.

Jiang, M., Hendrickson, C. T., and Vanbriesen, J. M., 2014, Life Cycle Water Consumption and Wastewater Generation Impacts of a Marcellus Shale Gas Well: Environmental Science \& Technology, v. 48, no. 3, p. 1911-1920.

Kendall, C., and Coplen, T. B., 2001, Distribution of oxygen-18 and deuterium in river waters across the United States: Hydrological Processes, v. 15, no. 7, p. 13631393.

Kentucky Geological Survey (KGS), 2020, Kentucky Groundwater Data Repository: https://kgs.uky.edu/kgsweb/DataSearching/watersearch.asp (accessed March 2020).

King, G. E., 2012, Hydraulic Fracturing 101: What Every Representative, Environmentalist, Regulator, Reporter, Investor, University Researcher, Neighbor and Engineer Should Know About Estimating Frac Risk and Improving Frac Performance in Unconventional Gas and Oil Wells, SPE Hydraulic Fracturing Technology Conference: The Woodlands, Texas, USA, Society of Petroleum Engineers, p. 80.

Krouse, H., and Mayer, B., 2000, Sulphur and Oxygen Isotopes in Sulphate, in Cook, P. G., and Herczeg, A. L., eds., Environmental tracers in subsurface hydrology: Boston, Kluwer Academic Publishers, p. 195-231.

Lang, S. Q., Bernasconi, S. M., and Früh-Green, G. L., 2012, Stable isotope analysis of organic carbon in small $(\mu \mathrm{g} \mathrm{C})$ samples and dissolved organic matter using a 
GasBench preparation device: Rapid Communications in Mass Spectrometry, v. 26, no. 1, p. 9-16.

LeDoux, S. M., Szynkiewicz, A., Faiia, A. M., Mayes, M. A., McKinney, M. L., and Dean, W. G., 2016, Chemical and isotope compositions of shallow groundwater in areas impacted by hydraulic fracturing and surface mining in the Central Appalachian Basin, Eastern United States: Applied Geochemistry, v. 71, p. 73-85.

Li, Z., You, C., Gonzales, M., Wendt, A. K., Wu, F., and Brantley, S. L., 2016, Searching for anomalous methane in shallow groundwater near shale gas wells: Journal of Contaminant Hydrology, v. 195, p. 23-30.

McIntosh, J. C., Hendry, M. J., Ballentine, C., Haszeldine, R. S., Mayer, B., Etiope, G., Elsner, M., Darrah, T. H., Prinzhofer, A., Osborn, S., Stalker, L., Kuloyo, O., Lu, Z. T., Martini, A., and Lollar, B. S., 2019, A Critical Review of State-of-the-Art and Emerging Approaches to Identify Fracking-Derived Gases and Associated Contaminants in Aquifers: Environmental Science \& Technology, v. 53, no. 3, p. 1063-1077.

McMahon, P. B., Belitz, K., Barlow, J. R. B., and Jurgens, B. C., 2017, Methane in aquifers used for public supply in the United States: Applied Geochemistry, v. 84, p. 337-347.

McMahon, P. B., and Chapelle, F. H., 2008, Redox Processes and Water Quality of Selected Principal Aquifer Systems, v. 46, no. 2, p. 259-271.

McMahon, P. B., Thomas, J. C., Crawford, J. T., Dornblaser, M. M., and Hunt, A. G., 2018, Methane in groundwater from a leaking gas well, Piceance Basin, Colorado, USA: Science of the Total Environment, v. 634, p. 791-801.

Milkov, A. V., and Etiope, G., 2018, Revised genetic diagrams for natural gases based on a global dataset of $>20,000$ samples: Organic Geochemistry, v. 125, p. 109-120.

Minns, S. A., 1993, Conceptual model of local and regional ground-water flow in the eastern Kentucky coal field: Kentucky Geological Survey, University of Kentucky, 194 p.

Molofsky, L. J., Connor, J. A., McHugh, T. E., Richardson, S. D., Woroszylo, C., and Alvarez, P. J., 2016a, Environmental Factors Associated With Natural Methane Occurrence in the Appalachian Basin: Groundwater, v. 54, no. 5, p. 656-668.

Molofsky, L. J., Connor, J. A., Wylie, A. S., Wagner, T., and Farhat, S. K., 2013, Evaluation of Methane Sources in Groundwater in Northeastern Pennsylvania: Groundwater, v. 51, no. 3, p. 333-349.

Molofsky, L. J., Richardson, S. D., Gorody, A. W., Baldassare, F., Black, J. A., McHugh, T. E., and Connor, J. A., 2016b, Effect of Different Sampling Methodologies on Measured Methane Concentrations in Groundwater Samples: Groundwater, v. 54, no. 5, p. 669-680.

Molofsky, L. J., Richardson, S. D., Gorody, A. W., Baldassare, F., Connor, J. A., McHugh, T. E., Smith, A. P., Wylie, A. S., and Wagner, T., 2018, Purging and other sampling variables affecting dissolved methane concentration in water supply wells: Science of The Total Environment, v. 618, p. 998-1007.

Mook, W. G., Bommerson, J. C., and Staverman, W. H., 1974, Carbon isotope fractionation between dissolved bicarbonate and gaseous carbon dioxide: Earth and Planetary Science Letters, v. 22, no. 2, p. 169-176. 
Osborn, S. G., Vengosh, A., Warner, N. R., and Jackson, R. B., 2011, Methane contamination of drinking water accompanying gas-well drilling and hydraulic fracturing: Proceedings of the National Academy of Sciences, v. 108, no. 20, p. 8172-8176.

Parkhurst, D. L., and Appelo, C. A. J., 2013, Description of input and examples for PHREEQC version 3: a computer program for speciation, batch-reaction, onedimensional transport, and inverse geochemical calculations, 6-A43, $519 \mathrm{p}$.

Parris, T. M., and Nuttall, B. C., 2020, Berea Sandstone: new developments in a mature oil and gas play, eastern Kentucky and Ohio: AAPG Bulletin (in press).

Rice, A. K., McCray, J. E., and Singha, K., 2018, Methane Leakage From Hydrocarbon Wellbores into Overlying Groundwater: Numerical Investigation of the Multiphase Flow Processes Governing Migration: Water Resources Research, v. 54, no. 4, p. 2959-2975.

Rice, C. L., 2001, Pennsylvanian system, in McDowell, R. C., ed., The geology of Kentucky; a text to accompany the Geologic Map of Kentucky: USGS Professional Paper 1151-H, online version 1.0. https://pubs.usgs.gov/pp/p1151h/penn.html

Rivard, C., Bordeleau, G., Lavoie, D., Lefebvre, R., and Malet, X., 2018, Temporal variations of methane concentration and isotopic composition in groundwater of the St. Lawrence Lowlands, eastern Canada: Hydrogeology Journal, v. 26, no. 2, p. 533-551.

Schlegel, M. E., McIntosh, J. C., Bates, B. L., Kirk, M. F., and Martini, A. M., 2011, Comparison of fluid geochemistry and microbiology of multiple organic-rich reservoirs in the Illinois Basin, USA: Evidence for controls on methanogenesis and microbial transport: Geochimica et Cosmochimica Acta, v. 75, no. 7, p. 19031919.

Sherwood, O. A., Rogers, J. D., Lackey, G., Burke, T. L., Osborn, S. G., and Ryan, J. N., 2016, Groundwater methane in relation to oil and gas development and shallow coal seams in the Denver-Julesburg Basin of Colorado: Proceedings of the National Academy of Sciences, v. 113, no. 30, p. 8391-8396.

Siegel, D. I., Azzolina, N. A., Smith, B. J., Perry, A. E., and Bothun, R. L., 2015, Methane Concentrations in Water Wells Unrelated to Proximity to Existing Oil and Gas Wells in Northeastern Pennsylvania: Environmental Science \& Technology, v. 49, no. 7, p. 4106-4112.

Strąpoć, D., Mastalerz, M., Dawson, K., Macalady, J., Callaghan, A. V., Wawrik, B., Turich, C., and Ashby, M., 2011, Biogeochemistry of Microbial Coal-Bed Methane: Annual Review of Earth and Planetary Sciences, v. 39, no. 1, p. 617656.

Torres, M. E., Mix, A. C., and Rugh, W. D., 2005, Precise $\delta 13 \mathrm{C}$ analysis of dissolved inorganic carbon in natural waters using automated headspace sampling and continuous-flow mass spectrometry: Limnology and Oceanography: Methods, v. 3, no. 8, p. 349-360.

Van Stempvoort, D., Maathuis, H., Jaworski, E., Mayer, B., and Rich, K., 2005, Oxidation of fugitive methane in ground water linked to bacterial sulfate reduction: Groundwater, v. 43, no. 2, p. 187-199. 
Vengosh, A., Jackson, R. B., Warner, N., Darrah, T. H., and Kondash, A., 2014, A Critical Review of the Risks to Water Resources from Unconventional Shale Gas Development and Hydraulic Fracturing in the United States: Environmental Science \& Technology., v. 48, no. 15, p. 8334-8348.

Vidic, R. D., Brantley, S. L., Vandenbossche, J. M., Yoxtheimer, D., and Abad, J. D., 2013, Impact of Shale Gas Development on Regional Water Quality: Science, v. 340 , no. 6134, p. 1235009.

Whiticar, M. J., 1999, Carbon and hydrogen isotope systematics of bacterial formation and oxidation of methane: Chemical Geology, v. 161, no. 1, p. 291-314.

Wilson, J., Munizzi, J., and Erhardt, A. M., 2020, Preservation methods for the isotopic composition of dissolved carbon species in non-ideal conditions: Rapid Communications in Mass Spectrometry, v. 34, no. 21, p. e8903.

Wolfe, A. L., and Wilkin, R. T., 2017, Evidence of Sulfate-Dependent Anaerobic Methane Oxidation within an Area Impacted by Coalbed Methane-Related Gas Migration: Environmental Science \& Technology, v. 51, no. 3, p. 1901.

Wood, W. W., 1976, Guidelines for collection and field analysis of ground-water samples for selected unstable constituents, 01-D2, $29 \mathrm{p}$.

Wunsch, D. R., 1993, Ground-water geochemistry and its relationship to the flow system at an unmined site in the eastern Kentucky coal field: Kentucky Geological Survey, University of Kentucky, $128 \mathrm{p}$.

Zhou, Y., Guo, H., Lu, H., Mao, R., Zheng, H., and Wang, J., 2015, Analytical methods and application of stable isotopes in dissolved organic carbon and inorganic carbon in groundwater: Rapid Communications in Mass Spectrometry, v. 29, no. 19, p. 1827-1835.

Zhu, J. F., Parris, T. M., Taylor, C. J., Webb, S. E., Davidson, B., Smath, R., Richardson, S. D., Molofsky, L. J., Kromann, J. S., and Smith, A. P., 2018, Assessing Methane in Shallow Groundwater in Unconventional oil and Gas Play Areas, Eastern Kentucky: Groundwater, v. 56, no. 3, p. 413-424. 
VITA

\section{Cristopher Steven Alvarez Villa}

Education

B.S. Geology (2018)

University of Illinois at Urbana-Champaign

Experience

Graduate Teaching Assistant

Department of Earth and Environmental Sciences

University of Kentucky, 40506

Laboratory Assistant

Illinois Sustainable Technology Center

University of Illinois - Prairie Research Institute, 61820

Scholastic Honors

Lyman T. Johnson Fellowship 